\title{
EDISON DE QUEIROZ JUNIOR
}

Formação Continuada de Professores para o Atendimento Educacional Especializado: Desafios e Perspectivas.

São Paulo 


\section{EDISON DE QUEIROZ JUNIOR}

Formação Continuada de Professores para o Atendimento Educacional Especializado: Desafios e Perspectivas.

Dissertação apresentada à Faculdade de Educação da Universidade de São Paulo, para obtenção do titulo de Mestre em Educação.

Área de Concentração: Educação Especial.

Orientadora: Prof ${ }^{a}$ Dra. Maria Luisa Sprovieri Ribeiro

São Paulo 
AUTORIZO A REPRODUÇÃO E DIVULGAÇÃO TOTAL OU PARCIAL DESTE TRABALHO, POR QUALQUER MEIO CONVENCIONAL OU ELETRÔNICO, PARA FINS DE ESTUDO E PESQUISA, DESDE QUE CITADA A FONTE.

Catalogação na Publicação

Serviço de Biblioteca e Documentação

Faculdade de Educação da Universidade de São Paulo

$371.9 \quad$ Queiroz Junior, Edison de

Q38f Formação continuada de professores para o atendimento educacional especializado: desafios e perspectivas / Edison de Queiroz Junior; orientação Maria Luisa Sprovieri Ribeiro. São Paulo: s.n., 2010.

$$
117 \text { p.; CD-ROM }
$$

Dissertação (Mestrado - Programa de Pós-Graduação em Educação. Área de Concentração: Educação Especial) - Faculdade de Educação da Universidade de São Paulo.

1. Educação especial 2. Atendimento educacional especializado 3. Formação de professores 4. Deficiente mental I. Ribeiro, Maria Luisa Sprovieri, orient. 


\section{Folha de Aprovação}

\section{Edison de Queiroz Junior}

Formação Continuada de Professores para o Atendimento Educacional Especializado: Desafios e Perspectivas.

Dissertação apresentada à Faculdade de Educação da Universidade de São Paulo, para obtenção do titulo de Mestre em Educação.

Área de Concentração: Educação Especial.

\section{BANCA EXAMINADORA:}

Maria Luisa Sprovieri Ribeiro - FEUSP

Neide de Aquino Noffs - PUC / SP

Roseli Cecília Rocha de Carvalho Baumel - FEUSP 
À Francisca, pelo exemplo sempre presente... 


\section{Agradecimentos}

À Prof ${ }^{a}$ Dra. Maria Luisa Sprovieri Ribeiro, pela disponibilidade em orientar a presente pesquisa e pela atenção e dedicação com que acompanhou minhas dúvidas, incertezas e questionamentos nesse percurso.

Aos professores que realizam o atendimento educacional especializado no município de São Bernardo do Campo, pela generosidade em dividir seu conhecimento, experiência, dúvidas e aspirações.

Aos professores que participaram da pesquisa, pela disponibilidade e as inúmeras contribuições que possibilitaram a realização desse trabalho.

À Prof ${ }^{a}$ Dra. Rosangela Gavioli Prieto, pelos questionamentos e indicações quando do exame de qualificação, que muito contribuíram com o desenvolvimento da pesquisa.

À Prof ${ }^{a}$ Dra. Roseli Cecília Rocha de Carvalho Baumel, pelas sugestões e indicações feitas no exame de qualificação que enriqueceram muito nosso trabalho.

Aos colegas da equipe de orientação técnica, com quem partilhei durante os últimos anos o desenvolvimento do trabalho com os professores do atendimento educacional especializado.

À Adriana e Maria Beatriz, por me acompanharem nessa trajetória.

À Renata, amiga e parceira nas formações, pelas inúmeras discussões que resultaram na proposta de pesquisa.

À Fatima e a Márcia, pela leitura exaustiva do original e pelas várias contribuições ao texto final.

À Andrea e Silvia, pela transcrição para o inglês. 


\section{Resumo}

QUEIROZ Jr. Edison. Formação continuada de professores para o atendimento educacional especializado: desafios e perspectivas. 2010. 117 p. Dissertação (Mestrado) - Faculdade de Educação, Universidade de São Paulo, 2010.

Os sistemas de ensino brasileiros, a partir das diretrizes nacionais para a educação inclusiva, viram-se frente à tarefa de se organizarem de modo a não apenas receber, mas atender, em suas necessidades, a todos os alunos matriculados em suas escolas. Entre outras ações, as diretrizes nacionais para a educação especial na educação básica, estabelecidas pelo Ministério da Educação, prevêem o atendimento educacional especializado, oferecido preferencialmente na rede regular de ensino. Para a realização desse atendimento, a Resolução CNE/CEB n 2/2001, propõe a atuação de professores especializados em educação especial. $\mathrm{O}$ presente estudo objetivou identificar as necessidades formativas apontadas por professores especializados em deficiência intelectual, atuando na rede municipal de ensino de São Bernardo do Campo, em São Paulo, bem como analisar as propostas de formação continuada desenvolvidas pela Secretaria Municipal de Educação de São Bernardo do Campo, entre os anos de 2005 e 2009, destinadas à formação desses professores. Para o desenvolvimento da pesquisa optamos por desenvolver uma investigação de campo, com abordagem qualitativa, utilizando como procedimentos para coleta de dados entrevistas semidirigidas com dez professores que atuam no atendimento educacional especializado para alunos com deficiência intelectual no município, além de documentos oficiais produzidos pela SMESBC relativos a ações formativas destinadas a esses professores. Para o estudo dos dados, além das referências teóricas, utilizamos a análise de conteúdo. Ao concluir o estudo, consideramos que os professores apontam diferentes necessidades formativas, relacionadas tanto às questões não contempladas em sua formação inicial quanto às mudanças no contexto educacional, mais especificamente aquelas propostas pela Política Nacional de Educação Especial na Perspectiva da Educação Inclusiva de 2008. As propostas desenvolvidas pela Secretaria de Educação ao longo dos cinco anos pesquisados, por diferentes razões, não se configuraram numa linha formativa que auxiliasse os professores na organização e estruturação do serviço no município. Os diferentes direcionamentos adotados pelas ações formativas oferecidas contribuíram significativamente para que não houvesse, por parte dos professores, uma coerência em relação às necessidades formativas apontadas.

PALAVRAS-CHAVE: Educação Especial, Atendimento Educacional Especializado, Formação de Professores, Deficiência Intelectual. 


\begin{abstract}
QUEIROZ Jr. Edison. Continued training of specialized educational teachers: challenges and prospects. 2010. 117 p. Dissertation (Masters) - Faculty of education, University of São Paulo, 2010.

Based on national guidelines for inclusive education, Brazilian educational systems are facing the task of organizing themselves in order to receive all students and really consider their special needs. Among many actions, National Guidelines for Special Education in Basic Education established by Brazilian Ministry of Education, demands special educational intervention preferentially at regular school. CNE/CEB Resolution No. 2/2001 proposes the intervention of specialized teachers to achieve this aim. The purpose of this study is to identify the training needs identified by their own teachers specialized in intellectual disability who works at (for) municipal schools of São Bernardo do Campo, São Paulo, and examine proposals for continued training offered by Municipal Department of Education of São Bernardo do Campo, between 2005 and 2009. The research uses a qualitative method developed by semiguided interviews for data collection with ten teachers who works at specialized educional service in municipal schools and also the study of official documents from SMESBC related to formative actions for the specialized teachers. Data analysis was done by theoretical references as well as content analysis. We realized that teachers suggest different training needs related to contents s not included in their initial training as well as those related to the changes occurred on the educational context, more specifically those proposed by the national policy of special education in the perspective of inclusive education, 2008. The proposals developed by Education Department over the five years studied, due to many reasons, did not show a 1 training direction which would help teachers organize and structure municipal service. The differente directions adopted by formative actions contributed significantly to the fact that teachers training needs are not coherent.
\end{abstract}

KEYWORDS: special education, Specialized Educational Service, teacher training, intellectual disabilities. 


\section{Lista de Quadros}

QUADRO 1 - Identificação dos entrevistados em elação ao tipo, tempo e local da formação inicial e outras formações obtidas após a graduação.

QUADRO 2 - Identificação dos entrevistados em relação ao tempo de trabalho como professor especializado, tempo de serviço na rede municipal de São Bernardo do Campo, tempo de trabalho na sala de recursos do município, atuação em outras redes e outras 59 experiências de trabalho.

QUADRO 3 - Temas e categorias das entrevistas......................................... 60

QUADRO 4 - Categorias do tema: Avaliação da proposta de trabalho.............. 61

QUADRO 5 - Categorias do tema: Público atendido pela sala de recursos.............................................................................. 62

QUADRO 6 - Categorias do tema: Formação.................................................. 62

QUADRO 7 - Temas apontados pelos professores entrevistados....................... 78

QUADRO 8 - Formações contratadas pela Secretaria de Educação de São Bernardo do Campo entre os anos de 2006 e 2010...................... 80

QUADRO 9 - Objetivos das formações, de acordo com os formadores............... 81

QUADRO 10 - Justificativa da contratação das formações, de acordo com a Secretaria de Educação.............................................................. 82

QUADRO 11 - Formações propostas pela Equipe de Orientação Técnica da Secretaria de Educação de São Bernardo do Campo.................... 84 


\section{Lista de Abreviaturas e Siglas}

AEE - Atendimento Educacional Especializado

APAE - Associação de Pais e Amigos dos Excepcionais

CEB - Câmara de Educação Básica

Cenesp - Centro Nacional de Educação Especial

CMAPDV - Centro Municipal de Apoio ao Portador de Deficiência Visual

CMAPE - Centro Municipal de Apoio Pedagógico Especializado

CNE - Conselho Nacional de Educação

DGD - Distúrbio Global do Desenvolvimento

DSM - Diagnostic and Statistical Manual of Mental Disorders

EMEBE - Escola Municipal de Educação Básica Especial

EOT - Equipe de Orientação Técnica

FMU - Faculdades Metropolitanas Unidas

Fundeb

- O Fundo de Manutenção e Desenvolvimento da Educação Básica e de Valorização dos Profissionais da Educação

HTPC - Horário de Trabalho Pedagógico Coletivo

IBC - Instituto Benjamim Constant

Inep - Instituto Nacional de Estudos e Pesquisas Educacionais Anísio Teixeira

INES - Instituto Nacional de Educação de Surdos

LDB - Lei de Diretrizes e Bases da Educação Nacional

LIBRAS - Língua Brasileira de Sinais

MEC - Ministério da Educação

ONG - Organização Não Governamental

PC - Paralisia Cerebral

PNE - Plano Nacional de Educação

PNEE - Política Nacional de Educação Especial

PUC - Pontifícia Universidade Católica

SE - Secretaria de Educação

SBC - São Bernardo do Campo 
SEC - Secretaria de Educação e Cultura

SEDUC-MT - Secretaria de Educação de Mato Grosso

Seesp - Secretaria de Educação Especial

SMESBC - Secretaria Municipal de Educação de São Bernardo do Campo

TGD - Transtorno Global do Desenvolvimento

UNILUS - Centro Universitário Lusíada 


\section{Sumário}

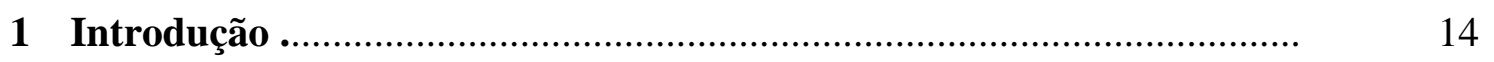

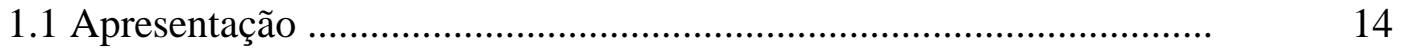

1.2 Metodologia de Pesquisa ..................................................................... 24

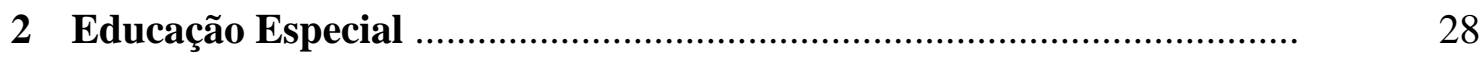

2.1 A Educação Especial em São Bernardo do Campo ........................... 37

3 Formação de Professores .....................................................................

3.1 A Formação Docente em Educação Especial ....................................

3.2 Formação Continuada ………………………………………........ 50

4 Análise e Discussão dos Dados .............................................................

4.1 Metodologia de Análise .................................................................. 57

4.2 Apresentação dos Dados das Entrevistas........................................... 58

4.3 Síntese dos Temas e Categorias das Entrevistas..................................... $\quad 60$

4.4 Síntese Descritiva das Entrevistas ...................................................... 61

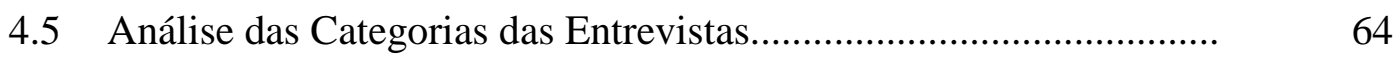

4.5.1 Organização/Estruturação do trabalho...........................................

4.5.2 Contexto/Interferências................................................................

4.5.3 Papel do professor da sala de recursos.......................................... 68

4.5.4 Diversidade de público............................................................... $\quad 69$

4.5.5 Equívocos nos encaminhamento..................................................

4.5.6 Referências gerais à formação........................................................

4.5.7 Formação inicial....................................................................... 
4.5.8 Formações externas, contratadas pela Secretaria de Educação de São Bernardo do Campo.......................................

4.5.9 Formações internas, sob a coordenação de profissionais da própria Secretaria de Educação de São Bernardo do Campo

4.5.10 Propostas de formação - organização.................................... 76

4.5.11 Propostas de formação - temas.............................................. 78

4.6 Apresentação e Discussão dos Dados dos Documentos.................................................................................... 80

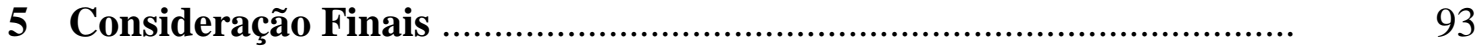

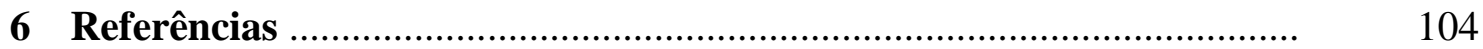

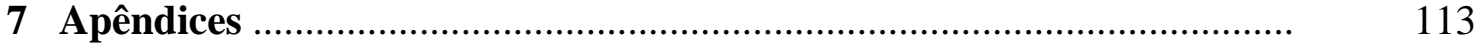




\section{INTRODUÇÃO}

\subsection{Apresentação}

Ao tornar-se signatário de documentos internacionais, como a Declaração Mundial sobre Educação para Todos (Tailândia, 1990) e a Declaração de Salamanca (Espanha, 1994), o Brasil, em consonância com o princípio de igualdade expresso na Constituição Federal de 1988, e de acordo com a Lei de Diretrizes e Bases da Educação Nacional (LDB) - Lei no 9.394/96, o Plano Nacional de Educação (PNE), Lei n ${ }^{\circ}$ 10.172/2001, além de outros documentos oficiais, assume o compromisso de promover a educação para todos.

A partir dessa legislação, os sistemas de ensino passam a enfrentar o desafio de se organizarem de modo que possam não apenas matricular, mas atender em suas necessidades a todos os alunos.

Com o objetivo de fornecer diretrizes aos sistemas para a organização dos serviços de educação especial na educação básica, o Ministério da Educação, por meio do Conselho Nacional de Educação e da Câmara de Educação Básica (CNE/CEB), formula o Parecer nº 17/2001, que entre outras ações, estabelece o atendimento educacional especializado (AEE) ${ }^{1}$ preferencialmente na rede regular de ensino, para alunos com necessidades educacionais especiais ${ }^{2}$, compreendidos como aqueles que:

[...] durante o processo educacional, demonstram:

\footnotetext{
${ }^{1}$ Assim é definido pelo Parecer CEB/CNE n ${ }^{\circ}$ 17/2001 o atendimento educacional especializado: “[...] são os serviços educacionais diversificados oferecidos pela escola comum para responder às necessidades educacionais especiais do educando [...] (BRASIL, 2001b. p. 19)

2 Optamos por manter a definição de necessidades educacionais especiais, conforme proposta pelo texto do Parecer do CNE/CEB n ${ }^{\circ} 17 / 2001$, em contraposição as definições propostas pela Política Nacional de Educação Especial na Perspectiva da Educação Inclusiva, por duas razões: em primeiro lugar, durante a elaboração da proposta de pesquisa e inicio de nossos estudos, esta era a definição que orientava os sistemas de ensino na organização e implantação de serviços de educação especial para atendimento aos alunos; depois, porque foi a partir também dessa definição que se organizou e manteve ao longo dos últimos nove anos, a proposta de atendimento educacional especializado no município de São Bernardo do Campo, que foi nosso objeto de pesquisa.
} 
2.1 - dificuldades acentuadas de aprendizagem ou limitações no processo de desenvolvimento que dificultem o acompanhamento das atividades curriculares, compreendidas em dois grupos:

2.1.1 aquelas não vinculadas a uma causa orgânica específica;

2.1.2 aquelas relacionadas a condições, disfunções, limitações ou deficiências.

2.2 - dificuldades de comunicação ou sinalização diferenciadas dos demais alunos, demandando a utilização de linguagens e códigos aplicáveis;

2.3 - altas habilidades/superdotação, grande facilidade de aprendizagem que os leve a dominar rapidamente conceitos, procedimentos e atitudes. (BRASIL, 2001b, p. 18)

Para a realização desse atendimento são previstos professores especializados em educação especial que deverão comprovar:

a) formação em cursos de licenciatura em educação especial ou em uma de suas áreas, preferencialmente de modo concomitante e associado à licenciatura para educação infantil ou para os anos iniciais do ensino fundamental;

b) complementação de estudos ou pós-graduação em áreas específicas da educação especial, posterior à licenciatura nas diferentes áreas de conhecimento, para atuação nos anos finais do ensino fundamental e no ensino médio (BRASIL, 2001b, p.14)

De acordo com o Parecer CNE/CEB $n^{\circ} 17 / 2001$, os serviços de apoio especializado podem ocorrer em:

Salas de recursos: serviço de natureza pedagógica, conduzido por professor especializado, que suplementa (no caso dos superdotados) e complementa (para os demais alunos) o atendimento educacional realizado em classes comuns da rede regular de ensino. Esse serviço realiza-se em escolas, em local dotado de equipamentos e recursos pedagógicos adequados às necessidades educacionais especiais dos alunos, podendo estender-se a alunos de escolas próximas, nas quais ainda não exista esse atendimento. Pode ser realizado individualmente ou em pequenos grupos, para alunos que apresentem necessidades educacionais especiais semelhantes, em horário diferente daquele em que frequentam a classe comum.

Itinerância: serviço de orientação e supervisão pedagógica desenvolvida por professores especializados que fazem visitas periódicas às escolas para trabalhar com os alunos que apresentem necessidades educacionais especiais e com seus respectivos professores de classe comum da rede regular de ensino. (BRASIL, 2001b, p. 23) 
Em São Bernardo do Campo os professores especializados estão divididos em três grupos, considerando sua formação e as áreas de atuação estabelecidas pela Secretaria Municipal de Educação de São Bernardo do Campo (SMESBC): professores especializados em deficiência intelectual $^{3}$, em deficiência auditiva e em deficiência visual. Como condição de ingresso, todos devem comprovar formação em pedagogia com habilitação em uma das áreas acima ou curso de pós-graduação (especialização) em educação especial.

Com o processo de municipalização, iniciado em 1998, a cidade de São Bernardo do Campo iniciou o atendimento aos alunos dos quatro primeiros anos do ensino fundamental. A rede municipal de ensino passou então a ser composta por creches, escolas de educação infantil, ensino fundamental e educação especial. Esse processo acentuou a necessidade de se ampliarem as discussões sobre o atendimento aos alunos com necessidades educacionais especiais.

A partir dessa necessidade foi constituído um grupo com profissionais das seções de educação infantil e de educação especial ${ }^{4}$, com a tarefa de traçar diretrizes únicas para a inclusão de alunos com necessidades educacionais especiais nas escolas da rede municipal. Partindo das diretrizes traçadas por esse grupo, a SMESBC estabeleceu, ao final de 1999, a implantação do atendimento educacional especializado em sala de recursos para aos alunos matriculados nos anos iniciais do ensino fundamental na rede municipal, definindo assim esse serviço:

Trata-se, pois, de um serviço pedagógico complementar realizado pelo professor especializado, que se utiliza de recursos e materiais didáticos específicos e adequados às necessidades especiais dos alunos, que frequentarão esta sala em horário inverso ao da classe regular, com frequência mínima de duas vezes por semana e duração mínima de 1 hora. (SBC, 1999, p. 18-19, grifo nosso)

O Parecer do CNE/CEB n 17/2001 estabelece o âmbito de ação, bem como a formação, já mencionada, necessária ao professor especializado em educação especial:

a) São considerados professores especializados em educação especial aqueles que desenvolveram competências para identificar as necessidades educacionais

\footnotetext{
${ }^{3}$ O termo "deficiência intelectual" surgiu em 1995, no Simpósio intitulado Intelectual disability: programs, policies and plannning for the future, quando a Organização Mundial da Saúde (OMS) propõe a substituição do termo "deficiência mental" por deficiência intelectual". Em 2004, na Declaração de Montreal sobre Deficiência Intelectual, em evento realizado pela OMS e pela Organização Pan-Americana da Saúde, é reafirmado o uso do termo em substituição à "deficiência mental".

${ }^{4}$ Esse grupo era composto por uma fonoaudióloga, uma orientadora pedagógica, duas professoras especializadas em educação especial e duas psicólogas.
} 
especiais, definir e implementar respostas educativas a essas necessidades, apoiar o professor da classe comum, atuar nos processos de desenvolvimento e aprendizagem dos alunos, desenvolvendo estratégias de flexibilização, adaptação curricular e práticas pedagógicas alternativas [...] (BRASIL, 2001b, p. 18)

Em relação ao locus dos serviços de educação especial, o Parecer prevê sua oferta nas escolas públicas e privadas da rede comum de ensino, indicando a implantação dos serviços de apoio pedagógico especializado, definidos como:

[...] serviços educacionais diversificados oferecidos pela escola comum para responder às necessidades educacionais especiais do educando. Tais serviços poder ser desenvolvidos:

a) nas classes comuns, mediante atuação de professor da educação especial, de professores intérpretes das linguagens e códigos aplicáveis e de outros profissionais; itinerância intra e interinstitucional e outros apoios necessários à aprendizagem, locomoção e comunicação;

b) em salas de recursos, nas quais o professor de educação especial realiza a complementação e/ou suplementação curricular, utilizando equipamentos e materiais específicos. (BRASIL, 2001b, p. 19)

Destacamos no presente estudo o atendimento educacional especializado realizado junto aos alunos com deficiência intelectual. A presença expressiva desse alunado no censo escolar nos últimos anos, bem com as questões que esse atendimento propõe tanto aos professores das classes comuns do ensino regular quanto da educação especial tem se configurado, em nossa opinião, num dos grandes desafios à educação.

De acordo com os dados apontados pelo Instituto Nacional de Estudos e Pesquisas Educacionais Anísio Teixeira (Inep), com base no Censo Escolar da Educação Básica de 2007, o número de alunos com deficiência intelectual matriculado em classes comuns do ensino regular e/ou educação de jovens e adultos no Brasil correspondia a 31,6\% do total de alunos com necessidades educacionais especiais matriculados nessas mesmas classes. Essa é a categoria com maior incidência na pesquisa realizada pelo referido instituto. Se tomarmos como referência as outras duas áreas atendidas pelos professores especializados em São Bernardo do Campo, veremos que a categoria cegueira, somada à baixa visão, representa 16,1\%, enquanto a surdez, acrescida da categoria deficiência auditiva, corresponde a $11 \%$ do número total de alunos com necessidades educacionais especiais (BRASIL, 2007). 
Em 2009, dos 46 professores que atuavam em salas de recursos e itinerância junto ao ensino fundamental em São Bernardo do Campo, 44 respondiam pelo atendimento aos alunos com deficiência intelectual e 2 pelo atendimento aos com deficiência auditiva. Em relação à deficiência visual, 15 professores respondiam por esse atendimento, atuando em um Centro de Apoio à Deficiência Visual, atendendo alunos da rede municipal e estadual, assim como outras crianças e adultos não matriculados na rede de ensino.

Além disso, conforme afirmam Batista e Mantoan (2005), a deficiência intelectual:

[...] coloca em xeque a função primordial da escola comum, que é a de produção do conhecimento, pois o aluno com essa deficiência tem uma maneira própria de lidar com o saber que, invariavelmente, não corresponde ao ideal da escola. $\mathrm{Na}$ verdade, não corresponder ao esperado pode acontecer com todo e qualquer aluno, mas os alunos com deficiência mental denunciam a impossibilidade de atingir esse ideal, de forma tácita. Eles não permitem que a escola dissimule essa verdade. As outras deficiências não abalam tanto a escola comum, pois não tocam no cerne e no motivo da sua urgente transformação: entender a produção do conhecimento acadêmico como uma conquista individual. (BATISTA; MANTOAN, 2005, p. 14)

Em nossa atuação junto aos professores que realizam o atendimento educacional especializado, acompanhamos tanto sua atividade nas diferentes escolas de ensino fundamental, quanto às ações formativas oferecidas pela SMESBC e que têm esse grupo como público-alvo.

De acordo com o Plano Nacional de Educação:

A formação continuada do magistério é parte essencial da estratégia de melhoria permanente da qualidade da educação, e visará à abertura de novos horizontes na atuação profissional. Quando feita na modalidade de educação à distância, sua realização incluirá sempre uma parte presencial, constituída, entre outras formas, de encontros coletivos, organizados a partir das necessidades expressas pelos professores. Essa formação terá como finalidade a reflexão sobre a prática educacional e a busca de seu aperfeiçoamento técnico, ético e político.

A formação continuada dos profissionais da educação pública deverá ser garantida pelas secretarias estaduais e municipais de educação, cuja atuação incluirá a coordenação, o financiamento e a manutenção dos programas como ação permanente e a busca de parceria com universidades e instituições de ensino superior. (BRASIL, 2001a, p. 99, grifo nosso)

Nesse sentido, os sistemas de ensino necessitam prever em sua organização a formação continuada de seus profissionais. Como afirma Prieto: 
A formação continuada do professor deve ser um compromisso dos sistemas de ensino comprometidos com a qualidade do ensino que, nessa perspectiva, devem assegurar que sejam aptos a elaborar e a implantar novas propostas e práticas de ensino para responder às características de seus alunos, incluindo aquelas evidenciadas pelos alunos com necessidades educacionais especiais. (PRIETO, 2006, p. 57)

A partir da definição do papel a ser desempenhado pelos professores de educação especial, conforme propõe o Parecer CNE/CEB nº 17/2001, e do estabelecimento de uma parceria com os professores do ensino regular, também responsáveis pelo atendimento aos alunos com necessidades educacionais especiais, é fundamental que sejam feitos investimentos na formação inicial e continuada desses profissionais, de forma a habilitá-los a oferecer condições adequadas de atendimento a esses alunos, para que se desenvolva um projeto de educação para todos.

Em nossa pesquisa sobre estudos nacionais que tenham como tema a formação continuada de professores e a educação inclusiva, encontramos diversos trabalhos com foco na formação dos professores das classes comuns para o atendimento dos alunos com necessidades educacionais especiais, como Fontoura (1994), Guhur (1991), Marques (2000), entre outros. Entretanto, poucos se referem aos professores especializados, o que nos leva a acreditar que nossa pesquisa poderá contribuir com as discussões nessa área, a partir de um recorte ainda pouco explorado pelo universo acadêmico.

Benda (2001) discute a formação dos professores de educação especial, tendo como fonte de dados entrevistas realizadas com nove professores que atuam em educação especial na cidade de Belo Horizonte e um professor de ensino superior que ministra disciplina relacionada à temática da educação especial. As questões formuladas buscavam levantar informações sobre o percurso formativo dos professores, bem como as motivações que os levaram a optar pela educação especial. Ao concluir, a autora aponta, em relação aos cursos universitários, que: "de uma forma geral, notamos que a área educacional relacionada à educação especial quando é trabalhada, é de uma forma superficial, não atendendo assim aos profissionais que atuam com a educação especial." Constata ainda, em relação aos profissionais entrevistados, a pouca contribuição da universidade para a atuação em educação especial. Reconhece o movimento de mudança que vem ocorrendo nas universidades, mas indica a necessidade de que elas ocorram num ritmo mais acelerado, acompanhando as mudanças educacionais. 
Ribeiro (2005), em pesquisa realizada em instituições públicas de ensino superior no estado do Paraná, analisou as contribuições oferecidas pelos cursos de especialização lato sensu em educação especial para o desenvolvimento de práticas pedagógicas inclusivas, por meio de questionários abertos e análise da organização curricular das referidas instituições. Constatou a necessidade de uma revisão nos conteúdos de algumas disciplinas e a inclusão de novas disciplinas para que os cursos oferecidos fossem adaptados à política de educação inclusiva.

Ao analisar a forma como o princípio da educação inclusiva vem sendo adotado pela rede do município de Ribeirão Preto, Vianna (2005), por meio de entrevistas com professores das classes regulares da rede pública e privada, conclui que há necessidade de investimentos tanto na formação de professores, quanto em aspectos estruturais para que os alunos com necessidades educacionais especiais possam ser realmente incluídos. Os professores entrevistados indicam a falta de formação para atendimento a essa clientela, bem como o desconhecimento, por parte da escola, das características e necessidades desses alunos. Em relação aos problemas estruturais, os professores indicam o grande número de alunos por classe, a falta de funcionários, além da falta de professores auxiliares e especialistas que apoiem a inclusão dos alunos.

Com o objetivo de analisar o programa Educação Inclusiva: direito à diversidade, Leodoro (2008) conclui que o programa representa uma evolução nas políticas públicas de formação docente, favorecendo o desenvolvimento da educação inclusiva. Analisando os materiais publicados pelo programa nos anos de 2004 e 2007, a autora aponta um avanço nas propostas relativas à formação de professores, com o reconhecimento, em 2007, da universidade como locus da formação continuada de professores, por meio de ações desenvolvidas em parceria com universidades públicas, em contraposição à postura adotada em 2004, que favorecia a realização de cursos por instituições particulares com financiamento estatal, configurando uma prática marcada pelo discurso neoliberal.

Silva (2008), analisando a influência dos cursos de formação continuada na aprendizagem profissional de professores de educação especial que atuam em sala de recursos, utiliza como instrumentos de coleta de dados a ficha de caracterização dos sujeitos e a entrevista semiestruturada. Ao discutir os dados coletados nas entrevistas realizadas com professores e gestores da Secretaria Estadual de Educação de Mato Grosso, conclui que a escolha profissional pelo magistério e, posteriormente, pela atuação na educação especial, não ocorreu, para a maioria dos entrevistados, de maneira deliberada, mas em função de outras circunstâncias, como a influência 
da família ou a falta de outras opções. Finaliza ainda com a afirmação dos professores de que a formação continuada oferecida pela Secretaria de Educação de Mato Grosso (SEDUC-MT), assim como a prática como professor em sala de recursos, são responsáveis por suas aprendizagens docentes.

No trabalho intitulado "Análise de uma proposta de formação continuada de professores no contexto da diversidade", Souza (2008) propõe como objetivo analisar a proposta de formação continuada do professor, desenvolvida pelos profissionais da equipe multidisciplinar da Secretaria de Educação de São Bernardo do Campo, que se desenvolveu entre os anos de 1996 e 2003. A autora discute o processo de formação continuada desenvolvida pelos técnicos da Secretaria de Educação junto aos professores de educação especial, questionando sua repercussão nas práticas dos professores e em sua visão sobre a deficiência, bem como sua contribuição para o enfrentamento das situações cotidianas, no atendimento à diversidade e na visão que têm sobre seu papel como professor. Conclui que a formação contribuiu com a atuação dos professores e indica a importância de um referencial de formação que favoreça a análise e reflexão dos professores para construção de novas práticas.

Picetti (2008) discute em sua pesquisa as relações entre o processo de tomada de consciência (conforme definido por Piaget), pelos professores e as possíveis transformações que ocorrem em sua prática pedagógica. Para realização da pesquisa organizou um grupo de estudos em uma cidade do interior do Rio Grande do Sul, formado por professores da rede estadual. A partir do referencial de Jean Piaget, aponta como resultado a importância do processo de tomada de consciência para a efetivação de mudanças nas práticas pedagógicas e a organização de um processo de formação que compreenda o planejamento, baseado nas necessidades dos professores, o estudo de referenciais teóricos e o trabalho coletivo.

As preocupações com a formação continuada de professores para a efetivação da educação inclusiva estão expressas tanto nas produções acadêmicas quanto em propostas governamentais, o que vem destacar, como mostram os estudos apresentados, a sua importância na efetivação das mudanças necessárias ao desenvolvimento de práticas que favoreçam o atendimento a todos os alunos.

Atuando, desde 2004, junto aos professores de educação especial que realizam o atendimento educacional especializado em sala de recursos da rede municipal de São Bernardo do Campo, enquanto profissional da Equipe de Orientação Técnica (EOT) do ensino 
fundamental, tanto no que diz respeito ao acompanhamento das ações realizadas nas diferentes escolas, quanto na organização de ações formativas dirigidas a esse grupo, sempre nos inquietaram as dúvidas, solicitações e queixas dos professores, tanto da sala de recursos quanto do ensino regular, sobre os alunos que apresentavam um laudo de deficiência intelectual fornecido por diferentes profissionais (psicólogos, neurologistas, pediatras ou neuropsicólogos), ou que, no dizer dos profissionais da escola, não obtinham avanços em sua aprendizagem, apesar dos diferentes investimentos realizados, às vezes ao longo de quatro ou cinco anos de escolarização.

Por diversas vezes vimo-nos envolvidos em discussões no contexto das escolas em que, além da questão do diagnóstico, estavam presentes dúvidas sobre o que ofertar a esses alunos, de que forma organizar a proposta da classe para que também atendesse às necessidades que apresentavam, como elaborar uma ação conjunta entre professores de sala de recursos e das classes comuns para que esses alunos pudessem se beneficiar das propostas desenvolvidas etc.

Em razão desses questionamentos, avaliamos importante investigar como esses profissionais, chamados a auxiliar os professores nas classes comuns no que diz respeito ao atendimento dos alunos com deficiência intelectual, eram contemplados pelas ações formativas desenvolvidas pela Secretaria de Educação (SE), bem como quais necessidades indicavam para a efetivação de sua ação profissional. Por esse motivo, após ingressarmos no curso de especialização intitulado "Escolarização e Diversidade", promovido pela Faculdade de Educação da Universidade de São Paulo em parceria com o Instituto de Psicologia da mesma Universidade, em 2007, concorremos ao ingresso no programa de mestrado, de forma a aprofundar nossos estudos sobre o tema.

Tomando como essencial o papel desempenhado por professores e gestores na implantação de um sistema inclusivo, dialogar com os professores de educação especial que atuam em sala de recursos dentro das escolas de ensino regular, trabalhando em conjunto com os professores das classes comuns no atendimento de alunos com deficiência intelectual, oferece a possibilidade de analisar como as indicações legais vêm se traduzindo em práticas. Esse diálogo auxilia-nos ainda a pensar como os professores especializados vêm se inserindo nessa nova proposta de atuação da educação especial.

Conscientes dos problemas enfrentados pela formação de professores no Brasil e considerando as atribuições dadas aos professores especializados pelo Parecer CNE/CEB $\mathrm{n}^{\circ}$ 
17/2001, avaliamos ser pertinente questionar quais têm sido as ações implementadas pelos sistemas de ensino, no sentido de fornecer uma formação continuada a esses profissionais em função das tarefas que lhes são propostas.

Dessa forma, o presente estudo pretende revelar alguns aspectos relativos à maneira como esses professores vêem as questões referentes à sua formação continuada, em função dos desafios que lhes são propostos pela implementação de um sistema inclusivo de educação, além de apontar como a Secretaria Municipal de Educação de São Bernardo do Campo (SMESBC) tem se organizado para oferecer-lhes formações que favoreçam seu desenvolvimento profissional e o atendimento aos alunos com necessidades educacionais especiais.

Considerando, portanto, a representatividade dessa categoria de deficiência nos dados do Censo Escolar (ainda que pesem imprecisões quanto ao seu diagnóstico), o número de alunos indicados pelas escolas municipais da rede de São Bernardo do Campo para o atendimento em sala de recursos para deficiência intelectual, o número de professores contratados para a realização do atendimento a esse público, bem como as dificuldades apontadas por esses professores em relação ao trabalho com a deficiência intelectual (que serão mais bem detalhadas nas próximas páginas) e a necessidade do oferecimento de formação continuada, começamos a refletir sobre a organização desse serviço e duas questões principais instigaram-nos à busca de respostas: quais são as necessidades formativas indicadas por esses professores e como a SMESBC tem organizado a formação continuada dos mesmos, frente à demanda que lhes é colocada?

Considerando essas questões, o presente estudo tem por objetivos:

1. Identificar quais são as necessidades formativas apontadas pelo grupo de professores que atua no atendimento aos alunos com deficiência intelectual, na modalidade de sala de recursos, na rede pública municipal de São Bernardo do Campo;

2. Investigar que ações formativas foram oferecidas no período de 2005 a 2009 pela Secretaria Municipal de Educação de São Bernardo do Campo aos professores de sala de recursos que atendem alunos com deficiência intelectual matriculados nas escolas municipais de ensino fundamental. 


\subsection{Metodologia de Pesquisa}

O campo das pesquisas em educação oferece ao pesquisador o desafio de compreender uma realidade em que inexiste uma causalidade linear entre os múltiplos fatores que determinam sua dinâmica. Se, no passado, acreditava-se na possibilidade de decompor os fenômenos educacionais em suas diferentes variáveis, isolando-os e quantificando-os, na tentativa e empreender o seu conhecimento, a própria evolução dos estudos na área mostrou a pouca eficácia dessa abordagem, que se restringe a um número limitado de objetos de investigação dentro do campo educacional. Essa constatação levou à necessidade de busca de outros métodos, não quantitativos, que pudessem atender às características do objeto de estudo.

Ora, à medida que avançam os estudos da educação, mais evidente se torna seu caráter de fluidez dinâmica de mudança natural a todo ser vivo. E mais claramente se nota a necessidade de desenvolvimento de métodos de pesquisa que atentem a esse caráter dinâmico. (LÜDKE; ANDRÉ, 1986, p. 5)

Assim, ao nos debruçarmos sobre a investigação das propostas de formação continuada implementadas pela SMESBC para os professores de educação especial que atendem alunos com deficiência intelectual em sala de recursos, optamos por desenvolver uma investigação de campo, com abordagem qualitativa, utilizando como procedimentos para a coleta de dados a entrevista e a análise documental.

Como se realiza cada vez de maneira exclusiva, seja com indivíduos ou com grupos, a entrevista permite correções, esclarecimentos e adaptações que a tornam sobremaneira eficaz na obtenção das informações desejadas. Enquanto outros instrumentos têm seu destino selado no momento em que saem das mãos do pesquisador que os elaborou, a entrevista ganha vida ao se iniciar o diálogo entre o entrevistador e o entrevistado. (LÜDKE; ANDRÉ, 1986 p. 34)

A pesquisa qualitativa, de acordo com Bodgan e Biklen (1994), apresenta cinco características básicas que julgamos contempladas no desenvolvimento do presente estudo. Essas características referem-se ao local onde o estudo é desenvolvido, bem como ao papel do pesquisador, em que deve privilegiar o ambiente natural onde os fatos se desenvolvem e o 
pesquisador como principal instrumento de investigação. Dizem respeito ainda aos dados a serem coletados, indicando o valor das descrições detalhadas de acontecimentos, pessoas e situações que possam auxiliar na compreensão da questão estudada. A preocupação com o processo também é uma das características dessa abordagem de pesquisa. Assim, é fundamental que o pesquisador realize sua investigação verificando como a questão colocada manifesta-se no cotidiano escolar. Na tentativa de compreender o dinamismo interno das situações, é importante que o pesquisador tenha um foco especial no significado que as pessoas envolvidas dão às questões colocadas. Para finalizar, a análise dos dados deverá ser precisada à medida que se avança no desenvolvimento da pesquisa, não havendo a preocupação de buscar a confirmação de hipóteses definidas a priori, ainda que isso não signifique que inexista um quadro teórico que oriente a coleta e análise de dados.

A entrevista, de acordo com Mazzoti e Gewandsznajder (1998), é um procedimento que possibilita a abordagem de temas complexos, atendendo ao interesse do pesquisador em compreender o significado que os sujeitos atribuem a eventos, situações, processos ou personagens que fazem parte de sua vida cotidiana.

Portanto, ao considerar as características propostas, optamos pela entrevista por entendermos que ela representa um importante instrumento de coleta de dados numa abordagem qualitativa, permitindo o acesso a diferentes públicos, bem como a retomada de questões que tenham ficado pouco claras num primeiro momento, o aprofundamento de outras e mesmo a inserção de pontos que não tenham sido levantados no início do estudo.

Bourdieu (1997) chama a atenção para algumas questões colocadas pela relação de pesquisa:

Ainda que a relação de pesquisa se distinga da maioria das trocas da existência comum, já que tem por fim o mero conhecimento, ela continua, apesar de tudo, uma relação social que exerce efeitos (variáveis segundo os diferentes parâmetros que a podem afetar) sobre os resultados obtidos. Sem dúvida a interrogação científica exclui por definição a intenção de exercer qualquer forma de violência simbólica capaz de afetar as respostas; acontece, entretanto, que nesses assuntos não se pode confiar somente na boa vontade, porque todo tipo de distorções estão inscritas na própria estrutura da relação de pesquisa. Estas distorções devem ser reconhecidas e dominadas; e isso na própria realização de uma prática que pode ser refletida e metódica, sem ser a aplicação de um método ou a colocação em prática de uma reflexão teórica. (BOURDIEU, 1997, p. 694) 
Considerar essas questões, com a consciência de que um grande esforço deverá ser empreendido no sentido de dominar seus efeitos, sem pretender anulá-los, é a atitude mais adequada a ser adotada pelo pesquisador. Uma estratégia utilizada por Bourdieu (1997) em seus estudos foi permitir que os pesquisadores pudessem escolher os pesquisados entre pessoas que fossem conhecidas ou que pudessem ser apresentadas a eles pelas pessoas conhecidas, buscando assim certa familiaridade entre pesquisador e pesquisado.

$\mathrm{Na}$ organização do presente estudo identificamos alguns fatores essenciais que avaliamos contemplar as características apontadas por Bodgan e Biklen (1994). Desenvolvemos uma pesquisa de campo baseada em dados colhidos junto aos professores que desenvolvem o trabalho em sala de recursos, no atendimento aos alunos com deficiência intelectual, bem como aos órgãos que formulam e implementam as propostas de formação no município; os documentos, assim como as ações dos profissionais, são produzidos num determinado contexto, que poderá ser expresso na análise do conteúdo das entrevistas, bem como dos demais dados coletados; a posição dos professores e sua visão sobre seu cotidiano estão presentes em cada questão formulada no roteiro de entrevista, sendo a análise realizada a partir dos dados apresentados, sem que partíssemos de hipóteses prévias. Além disso, o relacionamento profissional já estabelecido entre o entrevistador e os entrevistados auxiliou no desenvolvimento da entrevista, sendo importante, contudo, considerar as possíveis consequências desse fato.

Para realização do estudo foram entrevistados os dez professores que atuam no atendimento de alunos com deficiência intelectual na modalidade de sala de recursos na rede municipal de São Bernardo do Campo e que participaram da escrita do documento da rede municipal intitulado "Configurando o trabalho de itinerância em sala de recursos" em 2005. Essa escolha se justifica pela possibilidade de dialogar com interlocutores que vivenciaram todo o processo de organização desse serviço no período estudado. Durante esses cinco anos acompanhamos esse grupo de professores em seus momentos formativos, bem como em sua atuação direta nas escolas da rede municipal, o que avaliamos contribuir para a relação de familiaridade proposta por Bourdieu (1997).

Ao final de 2009 a rede municipal constituía-se de 68 escolas de ensino fundamental, contando com 46 professores de sala de recursos / itinerância, designados para o atendimento a alunos com deficiência intelectual, atuando em uma ou duas unidades escolares, de acordo com o número de alunos matriculados. 
As entrevistas foram gravadas, após autorização dos participantes que assinaram um termo de consentimento livre e esclarecido, sendo transcritas para realização das análises, garantindo-se o sigilo aos participantes com a substituição de seus nomes por letras. Foram realizadas nas escolas em que trabalham os professores, de acordo com a sua opção. Foram entrevistas semi-estruturadas, contando com um roteiro formulado previamente, mas que possibilitou ao entrevistador e ao entrevistado acrescentarem e aprofundarem aspectos que julgaram relevantes.

Além das entrevistas, realizou-se a coleta e análise de dados contidos nos documentos da SMESBC (justificativas formuladas pelos profissionais da Secretaria de Educação para contratação de formações, propostas de formação elaboradas pelos formadores, além das ações de formação organizadas pelos profissionais da equipe de orientação técnica do ensino fundamental) relativos às propostas de ações formativas desenvolvidas no período de 2005 a 2009, destinadas aos professores especializados que atuavam no atendimento em sala de recursos aos alunos com deficiência intelectual,

Para o estudo dos dados, além das referências teóricas, utilizamos a análise de conteúdo como definida por Bardin (1977):

Um conjunto de técnicas de análise das comunicações visando obter, por procedimentos sistemáticos e objetivos de descrição do conteúdo das mensagens, indicadores (quantitativos ou não) que permitam a inferência de conhecimentos relativos às condições de produção/recepção (variáveis inferidas) destas mensagens. (BARDIN, 1977, p. 42)

Após a leitura dos documentos e das entrevistas, as informações recolhidas foram organizadas em quadros e agrupadas em categorias de análise, permitindo a busca de significados que respondessem às questões propostas pela pesquisa e discutidas em capítulo posterior.

Por fim se apresentam as conclusões a partir das análises e se propõem novas pesquisas que aprofundem os dados levantados. 


\section{EDUCAÇÃO ESPECIAL}

Ao avaliar a organização da educação especial no Brasil, Jannuzzi (1992, p.20) destaca o fato de que a atenção à educação dos deficientes, notadamente dos deficientes intelectuais, equivalia à dada à educação em geral. Nesse sentido, para demonstrar a falta de preocupação com a educação primária, a autora chama a atenção para a situação da educação no país na segunda metade do século XVIII: “[...] em 1878 vamos ter: 15.561 escolas primárias, com 175 mil alunos, em 9 milhões de habitantes. Portanto apenas 2\% da população era escolarizada”.

As primeiras iniciativas de organização de serviços voltados ao atendimento das pessoas com deficiência foram marcadas pelas concepções da medicina. Exemplo desse fato é a criação, na época do império, do Serviço de Higiene e Saúde Pública, que teve grande influência no campo da educação. Do mesmo modo, no ano de 1911, em São Paulo, o serviço de inspeção médico-escolar foi responsável pela abertura de classes especiais e pela formação de recursos humanos para trabalhar com as pessoas com deficiência.

De acordo com Mazzotta (2001), essa relação entre medicina e pedagogia marcará as ações da educação especial nesse período. O modelo médico-pedagógico caracteriza-se por ações subordinadas aos médicos, responsáveis não apenas pela determinação dos diagnósticos, mas também pela orientação às práticas escolares.

Assim, em 1917, vamos encontrar a publicação, pelo Dr. Vieira de Mello, médico responsável pelo Serviço Médico-Escolar, de Débeis mentais na escola pública e Higiene escolar e pedagogia, o último contendo orientações para o funcionamento desse serviço, que entre outras atribuições, era responsável pela seleção da população que necessitava de atendimento diferenciado, bem como pela infra-estrutura necessária, incluindo a organização de classes especiais e a formação de pessoal.

Apesar de representar uma referência para organização dos serviços oferecidos a essa população no início do século passado, o documento não traz orientações sobre a forma como esse atendimento deveria se desenvolver, deixando os profissionais, tanto médicos quanto professores, sem indicações de como proceder em relação à educação dessas crianças.

No que diz respeito aos critérios utilizados para avaliar a "anormalidade", vamos encontrar a mesma situação, o que implicou na identificação de um grande número de pessoas 
com deficiência que, entretanto, continuaram a não contar com instituições adequadas para seu atendimento.

Nesse mesmo período, começa a inserir-se no Brasil, a partir da publicação de obras baseadas na escala métrica de avaliação da inteligência de Binet/Simon, o modelo psicopedagógico, caracterizado ainda pela ação médica, mas agora com ênfase nos princípios psicológicos.

É nesse cenário que vão surgir iniciativas de atendimento às pessoas com deficiência mental, tendo como marcos a criação, em 1926, do Instituto Pestalozzi de Canoas, no Rio Grande do Sul, da Sociedade Pestalozzi de Minas Gerais (1935), da Sociedade Pestalozzi do Estado do Rio de Janeiro (1948), da Sociedade Pestalozzi de São Paulo (1952), da Associação de Pais e Amigos dos Excepcionais (Apae) do Rio de Janeiro (1954) e da Apae de São Paulo, em 1961.

É característica do desenvolvimento da educação especial no Brasil a participação destas e de outras entidades filantrópicas, o que contribuiu, de acordo com Bueno (1973, p. 119), “[...] para que a deficiência permanecesse no âmbito da caridade pública e impedindo, assim, que as suas necessidades se incorporassem no rol dos direitos da cidadania”.

Em 1972, com a formulação do I Plano Setorial de Educação, o Ministério da Educação e do Desporto (à época), com a criação do Centro Nacional de Educação Especial (Cenesp), assume as diretrizes para a educação especial, constituindo ações cada vez mais organizadas e de cunho nacional, centralizando e articulando iniciativas no âmbito da educação especial.

A intenção de estabelecer e garantir o atendimento pedagógico em educação especial materializou-se em 1972 quando, por ocasião da formulação do I Plano Setorial de Educação, o Governo elegeu a educação especial como área prioritária. Em decorrência desse Plano, foi criado o Centro Nacional de Educação Especial (CENESP). Este fato reveste-se da maior importância, em qualquer análise histórica que se faça a respeito, por marcar o início das ações sistematizadas, visando à expansão e melhoria do atendimento educacional prestado no Brasil. (BRASIL, 1994, p. 28)

A partir de 1986, a Cenesp é transformada em Secretaria de Educação Especial (Seesp), mantendo, basicamente as mesmas atribuições e estrutura.

Atualmente, é à Secretaria de Educação Especial - SEESP/MEC, que cabem essas responsabilidades. Em consonância com as atribuições do Ministério da Educação e do Desporto, a SEESP coordena ações voltadas à formulação de 
políticas, oferece fomento técnico e financeiro, e promove as articulações necessárias ao aprimoramento da educação especial em OGs e em ONGs. Hoje, a administração do MEC coloca, em seu organograma, a educação especial no mesmo patamar administrativo dos demais graus de ensino. (BRASIL, 1994, p. 29).

Entre as ações desenvolvidas pela Seesp, encontra-se a publicação, em 1994, da Política Nacional de Educação Especial (PNEE), que tem como objetivo geral a:

[...] fundamentação e orientação do processo global da educação de pessoas portadoras de deficiência, de condutas típicas e de altas habilidades, criando condições adequadas para o desenvolvimento pleno de suas potencialidades, com vistas ao exercício consciente da cidadania. (BRASIL, 1994, p.45, grifos nossos)

Ao apresentar seu objetivo geral, o documento também explicita o público-alvo a que devem se direcionar as ações da educação especial:

É aquele que, por apresentar necessidades próprias e diferentes dos demais alunos no domínio das aprendizagens curriculares correspondentes à sua idade, requer recursos pedagógicos e metodologias educacionais específicas. Genericamente chamados de portadores de necessidades educacionais especiais, classificam-se em: portadores de deficiência (mental, visual, auditiva, física, múltipla), portadores de condutas típicas (problemas de conduta) e portadores de altas habilidades (superdotados). (BRASIL, 1994, p. 13)

Em relação ao locus do atendimento dos alunos, a PNEE/94 aponta a rede regular, entretanto essa indicação admite a sua exceção, ao afirmar que a matrícula deve ocorrer no ensino regular, "sempre que possível", criando ao mesmo tempo outras possibilidades de ingresso/atendimento.

$\checkmark \quad$ Expansão do atendimento aos portadores de necessidades especiais na rede regular e governamental de ensino.

$\checkmark \quad$ Ingresso do aluno portador de deficiência e de condutas típicas em turmas do ensino regular, sempre que possivel.

$\checkmark$ Organização do ambiente educacional o menos restritivo possível.

$\checkmark$ Conscientização da comunidade escolar para a importância da presença do alunado de educação especial em escolas da rede regular de ensino. (BRASIL, 1994, p. 49-51, grifos nossos). 
De modo semelhante, a LDB nº 9394/96, no capítulo dedicado à educação especial, ao referir-se à oferta dos serviços dessa modalidade de ensino indica que:

Art. 58. Entende-se por educação especial, para os efeitos desta Lei, a modalidade de educação escolar, oferecida preferencialmente na rede regular de ensino, para educandos portadores de necessidades especiais.

$\S 1^{\circ}$ Haverá, quando necessário, serviços de apoio especializado, na escola regular, para atender as peculiaridades da clientela de educação especial.

$\$ 2^{\circ} \mathrm{O}$ atendimento educacional será feito em classes, escolas ou serviços especializados, sempre que, em função das condições específicas dos alunos, não for possível a sua integração nas classes comuns do ensino regular. (BRASIL, 1996, p.19, grifos nossos)

De acordo com Minto (2000), o texto da LDB n 9394/96, apesar de trazer avanços ao reconhecer a educação especial como uma modalidade e de referir-se ao ensino regular como local onde os atendimentos devem ocorrer, causa preocupação ao denominar o público-alvo como "portadores de necessidades especiais" e ao utilizar o termo "preferencialmente" em relação ao atendimento oferecido na rede regular.

Entretanto, causa preocupação o uso dos termos portadores e preferencialmente. Portador traz implícita a ideia de carregar algo que, por ser "especial", não cabe no "lugar comum". Pode reforçar a idéia de excluir o diferente ao pressupor uma "falta" que, talvez, exceda em muito a dimensão dela própria. Por exemplo, é como se quando houvesse pane ou restrição de uma função humana - visão, movimento, audição, diferença no ritmo de apreensão de conhecimento etc. faltasse também um "atributo" essencial da normalidade. Preferencialmente pode ser o termo-chave para o não cumprimento do artigo, pois quem "dá primazia a" já tem arbitrada legalmente a porta de exceção (cf. Minto, 1996). (MINTO 2000, p. 8, grifos do autor)

A garantia da coexistência de espaços distintos para atendimento aos alunos com necessidades educacionais especiais (salas comuns nas escolas regulares, classes especiais e escolas especiais) também esta prevista em documentos posteriores à LDB no 9394/96, como a Resolução CNE/CEB n 2 de 2001, que em seus artigos 9 e 10 afirma:

Art. 9. As escolas podem criar, extraordinariamente, classes especiais, cuja organização fundamente-se no Capítulo II da LDBEN, nas diretrizes curriculares nacionais para a Educação Básica, bem como nos referenciais e parâmetros curriculares nacionais, para atendimento, em caráter transitório, a alunos que apresentem dificuldades acentuadas de aprendizagem ou condições de 
comunicação e sinalização diferenciadas dos demais alunos e demandem ajudas e apoios intensos e contínuos.

Art. 10. Os alunos que apresentem necessidades educacionais especiais e que requeiram atenção individualizada nas atividades de vida autônoma e social, recursos e apoios intensos e contínuos, bem como adaptações curriculares tão significativas que a escola comum não consiga prover, podem ser atendidos, em caráter extraordinário, em escolas especiais, públicas ou privadas, atendimento esse complementado, sempre que necessário e de maneira articulada, por serviços das áreas de Saúde, Trabalho e Assistência Social. (BRASIL, 2001c, p. $3)$.

No mesmo sentido, o Plano Nacional de Educação promulgado pelo Congresso Nacional em 2001 diz:

A legislação, no entanto, é sábia em determinar preferência para essa modalidade de atendimento educacional, ressalvando os casos de excepcionalidade em que as necessidades do educando exigem outras formas de atendimento. As políticas recentes do setor têm indicado três situações possíveis para a organização do atendimento: participação nas classes comuns, de recursos, sala especial e escola especial. Todas as possibilidades têm por objetivo a oferta de educação de qualidade. (BRASIL, 2001a, p.53)

Em relação a essas diferentes possibilidades de atendimento ofertadas aos alunos com necessidades educacionais especiais, criticadas por autores como Minto (2000), além de Mantoan e Fávero, no documento intitulado: $O$ acesso de alunos com deficiência às escolas e classes comuns da rede regular, publicado pela Procuradoria Federal dos Direitos do Cidadão em 2004, o Conselho Nacional de Educação, por meio do Parecer CNE/CEB nº 4/2002, elaborado pelo relator Carlos Roberto Jamil Cury, esclarece o uso da expressão preferencialmente, utilizado na Resolução CNE/CEB $n^{\circ}$ 2/2001, enquanto garantia de direito, e não como forma de discriminação desse alunado.

Importante destacar que o art. 6o. e o art. 9o. , § 2o. da Resolução CNE/CEB n ${ }^{\circ}$ 02/2001 torna imperativo consultar a família do estudante com necessidades educacionais especiais neste ir e vir do mesmo no movimento classe comum (regra comum) - classe especial (momento extraordinário dentro da regra comum).

Idêntico raciocínio, aí compreendido o papel da família, deve ser estendido ao disposto no art. 10 da Resolução que trata do mesmo movimento entre escola comum e escola especial. 
Assim, as classes especiais e as escolas especiais são transitórias e elas só podem deixar de sê-lo para determinados alunos se o consenso entre setores responsáveis da escola e família vier a se dar a este respeito.

Portanto, a referência normativa igualitária é a escola comum e a sala comum e só perante o retorno a elas, em vista da eliminação de um limite que dificulta uma dimensão de maior igualdade, é que se justifica a existência transitória de salas e escolas especiais.

As diretrizes insistem na sala comum da escola regular. Esta é a orientação eixo tanto para condizer com a norma quanto com a concepção contemporânea de inclusão. Os alunos com necessidades educacionais especiais, ordinariamente (no sentido de não apresentar condição particular), devem ser matriculados em escolas comuns das redes de ensino e dirigidos para as salas comuns das escolas. O Parecer, de maneira sábia, diz que apenas extra-ordinariamente o serão em salas especiais e mais extraordinariamente ainda em escolas especiais. O advérbio de modo (preferencialmente) que está no art. 208, III da CF e no art. 4o. III da LDB é o que possibilita, por contraste, o advérbio de modo (extraordinariamente). Neste sentido atende-se também o disposto na Declaração de Salamanca na seguinte orientação:

A escolarização de crianças em escolas especiais - ou classes especiais na escola regular - deveria ser uma exceção, só recomendável naqueles casos, pouco freqüentes, nos quais se demonstre que a educação nas classes comuns não pode satisfazer às necessidades educativas ou sociais da criança, ou quando necessário para o bem-estar da criança. (BRASIL, 2002 p. 11, grifos do autor)

Temos acompanhado em nossa prática as discussões a respeito do locus de atendimento dos alunos com necessidades educacionais especiais no município de São Bernardo do Campo e, de forma diferente à posição assumida pelo Parecer CNE/CEB n ${ }^{\circ} 4 / 2002$, o que temos visto ao longo dos últimos anos, são posicionamentos distintos assumidos em diferentes momentos pela SMESBC, com uma tendência que oscilou da manutenção e mesmo de certo incentivo ao encaminhamento de alunos para classes/escolas especiais (denominadas em São Bernardo do Campo, como classes integradas), como ocorreu em 2008, a uma orientação para matricula nas classes comuns das escolas regulares que nem sempre atendeu aos anseios das famílias.

Assim, concordamos com Minto (2000), ao constatarmos que as exceções anunciadas pela legislação marcaram muitas das discussões no município de São Bernardo do Campo em relação à matrícula de alunos com necessidades educacionais especiais que, até 2004, ocorriam tanto no ensino regular quanto nas escolas e classes especiais, além de instituições especializadas conveniadas com a prefeitura municipal. Progressivamente essas matrículas foram se ampliando no ensino regular, com a diminuição do número de alunos tanto nas escolas quanto nas classes especiais, assim como nas instituições especializadas. 
O MEC, em 2008, publicou o documento de Política Nacional de Educação Especial na Perspectiva da Educação Inclusiva, que assim define a educação especial e o atendimento educacional especializado:

A educação especial é uma modalidade de ensino que perpassa todos os níveis, etapas e modalidades, realiza o atendimento educacional especializado, disponibiliza os recursos e serviços e orienta quanto a sua utilização no processo de ensino e aprendizagem nas turmas comuns do ensino regular.

$\mathrm{O}$ atendimento educacional especializado tem como função identificar, elaborar e organizar recursos pedagógicos e de acessibilidade que eliminem as barreiras para a plena participação dos alunos, considerando suas necessidades específicas. As atividades desenvolvidas no atendimento educacional especializado diferenciam-se daquelas realizadas na sala de aula comum, não sendo substitutivas à escolarização. (BRASIL, 2008, p.10, grifos nossos).

Outra discussão importante diz respeito à definição do público a que se destina a educação especial. O texto do Parecer CNE/CEB no 17/2001 refere-se aos "alunos com necessidades educacionais especiais", expressão já utilizada pela PNEE/94, para designar esse público. Entretanto, ao contrário do documento da Política Nacional, que classificava essas necessidades educacionais especiais como deficiência (mental, visual, auditiva, física, múltipla), condutas típicas (problemas de conduta) e altas habilidades (superdotados), o Parecer amplia a possibilidade de atuação da educação especial para além da questão da deficiência.

Dentro dessa visão, a ação da educação especial amplia-se, passando a abranger não apenas as dificuldades de aprendizagem relacionadas a condições, disfunções, limitações e deficiências, mas também aquelas não vinculadas a uma causa orgânica específica, considerando que, por dificuldades cognitivas, psicomotoras e de comportamento, alunos são frequentemente negligenciados ou mesmo excluídos dos apoios escolares. (BRASIL, 2001, p. 20)

Entretanto, no cotidiano escolar, o que temos visto em nossa experiência é a utilização dessa definição como justificativa para o encaminhamento, aos serviços educacionais especializados, de alunos cujas dificuldades são resultado da própria organização do sistema escolar no que diz respeito à estruturação do currículo, ao sistema de avaliação, à formação deficitária dos professores e a outros problemas estruturais. Compreendemos que esses alunos não podem ser negligenciados, porém nos perguntamos a quem cabe a tarefa de fornecer as respostas educacionais de que eles precisam. 
Mais recentemente o MEC, com a publicação do documento Política Nacional de Educação Especial na Perspectiva da Educação Inclusiva, fornece orientações aos sistemas de ensino sobre a organização da educação especial. Entre outras questões, o texto propõe uma redefinição do público atendido pela educação especial.

Na perspectiva da educação inclusiva, a educação especial, de forma articulada com o ensino regular, passa a integrar a proposta pedagógica da escola, promovendo o atendimento às necessidades educacionais especiais de alunos com deficiência, transtornos globais de desenvolvimento e altas habilidades/superdotação. (BRASIL, 2008 p. 14)

Nesse mesmo sentido, o Decreto Federal nº 6.571, de 17 de setembro de 2008, também se pronuncia a respeito dos alunos que devem ser alvo do atendimento educacional especializado.

Art. $1^{\circ}$ A União prestará apoio técnico e financeiro aos sistemas públicos de ensino dos Estados, do Distrito Federal e dos Municípios, na forma deste Decreto, com a finalidade de ampliar a oferta do atendimento educacional especializado aos alunos com deficiência, transtornos globais do desenvolvimento e altas habilidades ou superdotação, matriculados na rede pública de ensino regular. (BRASIL, 2008).

Assim, retornamos, em relação à definição do público da educação especial, ao que estava proposto pela PNEE/94, ressalvando-se que a Política Nacional de Educação Especial na Perspectiva da Educação Inclusiva de 2008, baseada em discussões recentes de diferentes áreas, propõe uma nova definição do que é compreendido por deficiência, transtornos globais do desenvolvimento e altas habilidades/superdotação.

[...] considera-se pessoa com deficiência aquela que tem impedimentos de longo prazo, de natureza física, mental ou sensorial que, em interação com diversas barreiras, podem ter restringida sua participação plena e efetiva na escola e na sociedade. Os alunos com transtornos globais do desenvolvimento são aqueles que apresentam alterações qualitativas das interações sociais recíprocas e na comunicação, um repertório de interesses e atividades restrito, estereotipado e repetitivo. Incluem-se nesse grupo alunos com autismo, síndromes do espectro do autismo e psicose infantil. Alunos com altas habilidades/superdotação demonstram potencial elevado em qualquer uma das seguintes áreas, isoladas ou combinadas: intelectual, acadêmica, liderança, psicomotricidade e artes, além de apresentar grande criatividade, envolvimento na aprendizagem e realização de tarefas em áreas de seu interesse. (BRASIL, 2008, p. 9) 
Outra questão trazida por esse documento diz respeito à formação dos professores para atuação na educação especial.

Comparando o texto da Política Nacional de Educação Especial na Perspectiva da Educação Inclusiva com a proposta expressa na Resolução CNE/CEB no 2/2001, veremos que a resolução, em seu artigo 18, define que:

$\S 3^{\circ}$ Os professores especializados em educação especial deverão comprovar: I - formação em cursos de licenciatura em educação especial ou em uma de suas áreas, preferencialmente de modo concomitante e associado à licenciatura para educação infantil ou para os anos iniciais do ensino fundamental;

II - complementação de estudos ou pós-graduação em áreas específicas da educação especial, posterior à licenciatura nas diferentes áreas de conhecimento, para atuação nos anos finais do ensino fundamental e no ensino médio; (BRASIL, 2001b, p. 5)

Ao passo que a Política Nacional de 2008 determina que:

Para atuar na educação especial, o professor deve ter como base de sua formação, inicial e continuada, conhecimentos gerais para o exercício da docência e conhecimentos específicos da área que possibilitem a sua atuação no atendimento educacional especializado, nas salas comuns do ensino regular, nas salas de recursos, nos centros de atendimento educacional especializado, nos núcleos de acessibilidade das instituições de educação superior, bem como aprofundar seu caráter interativo junto às salas de recursos. (BRASIL, 2008, p. 11)

Ao expressar-se dessa forma em relação aos conhecimentos esperados para o exercício da docência na educação especial, o documento não deixa claro que tipo de formação os forneceria, se, como propõe a Resolução CNE/CEB no 2/2001, licenciatura em educação especial ou complementação de estudos/pós-graduação em áreas específicas da educação especial ou ainda outro tipo de formação.

A indicação de 2008 parece vir ao encontro de outra proposta, já desenvolvida pelo MEC desde 2007, a formação de professores de diferentes municípios brasileiros para o atendimento educacional especializado, integrando o Programa educação inclusiva: direito à diversidade. $\mathrm{O}$ curso de especialização em atendimento educacional especializado (AEE), desenvolvido na modalidade à distância, tem como proposta que os professores (com formação em pedagogia) tornem-se multiplicadores da formação, atingindo outros professores de seu próprio município e 
de municípios próximos, em uma atuação conjunta das prefeituras, do MEC e das universidades envolvidas e que se tornem professores do AEE.

Os desdobramentos das diretrizes fornecidas pelo documento da Política Nacional de Educação Especial na Perspectiva da Educação Inclusiva e de outras ações do Ministério da Educação, por meio da Secretária de Educação Especial (Seesp), como a formação apresentada, são ainda muito recentes e necessitam de acompanhamento e estudos para que se avalie seu impacto na organização da educação em geral e da educação especial, em particular.

É importante frisar, ao concluir, que é nesse cenário, carregado de contradições e ambiguidades, que realizamos nossa pesquisa. Acreditamos que com nosso estudo possamos contribuir com a área a partir da discussão da maneira como o sistema municipal de São Bernardo do Campo tem se organizado para, no cotidiano escolar, refletir essas orientações legais.

\subsection{A educação especial em São Bernardo do Campo}

Atualmente, o sistema municipal de ensino de São Bernardo do Campo conta com serviços de educação especial que complementam/suplementam, bem como substituem o atendimento nas classes comuns do ensino regular.

O município tem sua rede organizada no atendimento às áreas de educação infantil e ensino fundamental, além das modalidades de educação de jovens e adultos e educação especial. Em suas 159 unidades escolares, sendo 30 creches, 61 escolas de educação infantil, 55 exclusivamente de ensino fundamental e 13 que atendem tanto a educação infantil quanto o ensino fundamental, são atendidos, aproximadamente 90 mil alunos.

Existem hoje em São Bernardo do Campo duas escolas de educação especial, sendo uma voltada ao atendimento de crianças, jovens e adultos surdos, com perda auditiva severa e/ou profunda, nos oito primeiros anos do ensino fundamental, e uma para o atendimento dos alunos com deficiência intelectual. Essa última atende a uma demanda populacional que se configura por um: 
[...] alunado composto por crianças e jovens que apresentam significativo déficit cognitivo, associado a quadros variados de comprometimento incluindo deficiência neuromotora, sensoriais, alterações de ordem psíquica/emocional, distúrbios da comunicação, síndromes genéticas entre outras, reconhecendo suas particularidades e valorizando suas potencialidades. (SBC, 2006, p.40)

Para a complementação/suplementação do ensino regular, a rede conta, com o atendimento de um centro de apoio, de salas de recursos e do serviço de itinerância.

O Centro Municipal de Apoio ao Portador de Deficiência Visual (CMAPDV) "Nice Tonhozi Saraiva", que atende munícipes de qualquer faixa etária com cegueira ou baixa visão, oferece programas de atendimento direto: braile, sorobã, estimulação, orientação e mobilidade, recursos gráficos, habilidades individuais, grupo temático, educação física e o projeto surdocegueira/múltipla deficiência sensorial; e indireto: ensino itinerante, abrangendo escolas de educação infantil, ensino fundamental e educação especial, cursos de formação e informação para profissionais da educação e comunidade, além do núcleo de material adaptado.

Até 2009, para o atendimento às crianças de 0 a 6 anos matriculadas ou não nas escolas de educação infantil, havia o Centro Municipal de Apoio Pedagógico Especializado (CMAPE), que atendia crianças com distúrbios neuromotores, deficiências múltiplas, transtornos globais de desenvolvimento e/ou atrasos significativos de aprendizagem. Além do atendimento direto às crianças, realizado no CMAPE, havia o serviço de itinerância, que se caracterizava pelo trabalho desenvolvido pelo professor da educação especial junto ao professor de classes comuns e demais profissionais das escolas de educação infantil, com o objetivo de favorecer a aprendizagem dos alunos ali matriculados. A partir de 2010, atendendo ao princípio de descentralização dos serviços de educação especial, o CMAPE deixa de existir e os professores iniciam uma nova organização, buscando atender os alunos nas escolas em que estudam.

Outro recurso oferecido pela rede municipal é o atendimento em sala de recursos, compreendido como:

[...] serviço de natureza pedagógica, conduzido por professor especializado, que suplementa (no caso dos superdotados) e complementa (para os demais alunos) o atendimento educacional realizado em classes comuns da rede regular de ensino. (SBC, 2006, p. 20) 
A concretização desse serviço deu-se em 2000, a partir da implantação do Programa de Inclusão, sediado em uma Escola Municipal de Educação Básica Especial (EMEBE). Foi resultado de discussões e apontamentos das seções de educação especial e infantil em 1999, assumida pelos gestores da SMESBC, que indicavam a necessidade de criar um serviço educacional especializado que atendesse aos alunos com necessidades educacionais especiais matriculados nas classes comuns, como uma alternativa às classes especiais. Além do trabalho direto com os alunos, os professores especializados em educação especial nas áreas de deficiência intelectual, deficiência auditiva e visual realizam o serviço de itinerância. No período de 2000 a 2003 os alunos matriculados nas escolas de ensino fundamental eram avaliados pelo setor de diagnósticos da seção de educação especial e encaminhados, de acordo com essa avaliação, para o atendimento em sala de recursos ou outros serviços de educação especial. O atendimento era centralizado na Escola Municipal de Educação Básica Especial (EMEBE) Fernando de Azevedo e gerenciado pela seção de educação especial.

A partir de 2004, em razão de mudanças ocorridas na Secretaria Municipal de Educação, o serviço de atendimento educacional especializado nas áreas de deficiência intelectual e deficiência auditiva, passa a ser gerenciado pela seção de ensino fundamental, sendo o encaminhamento dos alunos realizado a partir de uma avaliação das equipes escolares (professores, coordenadores e equipes de gestão) em conjunto com técnicos dessa seção e professores da educação especial.

Nessa nova proposta, o serviço passa por uma progressiva descentralização, possibilitando aos alunos que sejam atendidos na mesma escola em que frequentam a classe comum. Em 2004, o grupo de professores com habilitação em deficiência intelectual era composto por dezessete profissionais, responsáveis pelo atendimento de quatro a cinco escolas cada um. A área de deficiência auditiva contava com três professores, atendendo em média cinco a seis escolas.

Ao final de 2009, em função da descentralização do serviço de sala de recursos, a rede contava com cinquenta e seis professores especializados em deficiência intelectual, atendendo a uma ou duas escolas de ensino fundamental. Os alunos atendidos caracterizam-se por apresentarem dificuldades acentuadas de aprendizagem relacionadas ou não à existência de deficiência, de acordo com a Resolução CNE/CEB nº 2/2001.

Como se pode perceber, convivem no município serviços de natureza diversa, com ações que representam as contradições existentes no campo da educação. São intensos os debates a 
respeito do atendimento mais adequado a ser oferecido aos alunos com necessidades educacionais especiais, espelhando as discussões atuais na área da educação especial. As ações adotadas pelos gestores municipais refletem, muitas vezes, essas contradições.

Com o desenvolvimento da presente pesquisa, acreditamos contribuir com esse debate, buscando dar, na medida do possível, visibilidade a alguns direcionamentos seguidos pelas propostas de formação e seus desdobramentos na prática cotidiana. 


\section{FORMAÇÃO DE PROFESSORES}

Como já indicamos ao falarmos sobre a educação especial no Brasil, o posicionamento dos governos em relação à educação, principalmente das camadas menos favorecidas economicamente, carece, desde o início, de objetivos claramente definidos e, principalmente, de ações que possam concretizar um projeto de educação para o país.

Em relação à formação de professores, o que podemos perceber, de acordo com Saviani (2009), é:

[...] a precariedade das políticas formativas, cujas sucessivas mudanças não lograram estabelecer um padrão minimamente consistente de preparação docente para fazer face aos problemas enfrentados pela educação escolar em nosso país. (SAVIANI, 2009, p. 148)

Inicialmente, sob a responsabilidade dos padres jesuítas, a educação brasileira ficou, durante muitas décadas, nas mãos de religiosos e alguns professores leigos, sem nenhum tipo de formação que os qualificasse para essa atividade.

Apesar da Constituição Imperial de 1824 estabelecer a instrução primária gratuita e aberta a todos os cidadãos, o governo central não adotou nenhuma medida em relação à preparação de professores para essa tarefa, deixando aos governos das províncias a responsabilidade pela instrução primária e pela formação de seus profissionais. De acordo com Rodrigues e Sobrinho (2006, p. 89), as escolas primárias continuaram “[...] formadas por mestres improvisados, sem uma preparação para o exercício da atividade docente".

Somente em 1835 surge, no Rio de Janeiro, ainda que muito precariamente, a primeira escola normal voltada para a formação de professores. Entretanto, as dificuldades por que passaram as escolas normais criadas em Niterói e em outras províncias iam desde a falta de estrutura física a problemas com horários de funcionamento, programação e, o que talvez fosse mais significativo, o total despreparo de seus professores, que se constituíam por engenheiros, bacharéis em direito, sacerdotes etc. Exemplo das dificuldades e da pouca adesão inicial à proposta de implantação das escolas normais nos é dado por Tanuri (2000): 
A primeira escola normal do Brasil teve duração efêmera, sendo suprimida em 1849. Aliás em 1840, após quatro anos de funcionamento, ela havia formado apenas 14 alunos, dos quais 11 se dedicaram ao magistério. [...] Na verdade, em todas as províncias as escolas normais tiveram uma trajetória incerta e atribulada, submetidas a um processo contínuo de criação e extinção, para só lograrem algum êxito a partir de 1870, quando se consolidam as idéias liberais de democratização e obrigatoriedade da instrução primária, bem como de liberdade de ensino. (TANURI, 2000, p.64)

Apesar dessa consolidação, as escolas normais continuaram a enfrentar muitos problemas, entre eles, um currículo muito limitado, poucos professores e uma duração de curso que não ultrapassava dois anos.

Ao deixar a formação de seu quadro de professores a cargo dos estados, a legislação brasileira favoreceu, desde o início, uma situação de desigualdade que permanece ainda hoje, como veremos ainda nesse capítulo.

Com o objetivo de melhor qualificar os docentes formados pela escola normal, a reforma da instrução pública no estado de São Paulo, efetivada em 1890, propõe o enriquecimento dos conteúdos curriculares desenvolvidos até então e uma ênfase em exercícios práticos de ensino, com a criação da escola-modelo anexa à escola normal. Essa reforma, iniciada na capital, estendeu-se ao interior paulista e tornou-se referência para outros estados do país.

Ampliando a proposta das escolas normais, considerando não apenas a dimensão de ensino, mas também a de pesquisa como objetivo dos espaços de formação surgem os institutos de educação, sendo o primeiro criado em 1932, no Distrito Federal, dirigido por Lourenço Filho, e o segundo implantado por Fernando de Azevedo, em 1933, na cidade de São Paulo, ambos inspirados pela Escola Nova (SAVIANI, 2009, p. 145).

Com a criação dos institutos de educação, firma-se o modelo pedagógico-didático de formação, em contraposição ao modelo de conteúdos culturais-cognitivos que prevalecia nas escolas normais.

[...] os institutos de educação foram pensados e organizados de maneira a incorporar as exigências da pedagogia, que buscava ser firmar como um conhecimento de caráter científico. Caminhava-se, pois decisivamente rumo à consolidação do modelo pedagógico-didático de formação docente que permitiria corrigir as insuficiências e distorções das velhas Escolas Normais [...]. (SAVIANI, 2009, p. 146) 
Em 1941, com a I Conferência Nacional de Educação, encontramos iniciativas do governo federal em relação à busca de normas centrais que garantissem uma base comum aos sistemas estaduais de formação de professores, bem como a indicação de uma política de remuneração do magistério, solicitando um regime salarial uniforme como forma de superar o momento precário pelo qual passava a categoria. Essas indicações, entretanto, não foram suficientes para reverter o quadro de desigualdades.

Dessa forma, de acordo com os dados do Censo Escolar de 1964:

[...] dos 289.865 professores primários em regência de classe em 1964, apenas 161.996, ou seja, 56\%, tinham realizado curso de formação profissional. Dos $44 \%$ de professores leigos, $71,60 \%$ tinham apenas curso primário (completo ou incompleto); $13,7 \%$, ginasial (completo ou incompleto); $14,6 \%$, curso colegial (completo ou incompleto). (TANURI, 2000, p.77)

Em 1971, com a promulgação da Lei 5.692/71, a profissionalização obrigatória para o magistério passa a ocorrer no segundo grau. Assim:

[...] a Lei determinava como formação mínima para o exercício do magistério: a) no ensino de $1^{\circ}$ grau, da $1^{\mathrm{a}}$ à $4^{\mathrm{a}}$ séries, habilitação específica de $2^{\circ}$ grau, realizada no mínimo em três séries; b) no ensino de $1^{\circ}$ grau, da $1^{\mathrm{a}}$ à $8^{\mathrm{a}}$ séries, habilitação específica de grau superior, representada por licenciatura de curta duração; c) em todo o ensino de $1^{\circ}$ e $2^{\circ}$ graus, habilitação específica de nível superior, correspondente à licenciatura plena. (TANURI, 2000, p. 81)

Durante os anos que se seguiram, em relação à educação básica, a formação que predominou foi a de nível médio, ocorrendo principalmente em estabelecimentos da rede pública.

A partir da promulgação da nova Lei de Diretrizes e Bases em 1996 (Lei 9.394/96), fica estabelecida a exigência de formação em nível superior para atuação na educação básica. Entretanto, de acordo com Saviani (2009), ao introduzir:

[...] como alternativa aos cursos de pedagogia e licenciatura os institutos superiores de educação e as Escolas Normais Superiores, a LDB sinalizou para uma política educacional tendente a efetuar um nivelamento por baixo: os institutos superiores de educação emergem como instituições de nível superior de segunda categoria, promovendo uma formação mais aligeirada, mais barata [...]. (SAVIANI, 2009, p. 148) 
Ao observarmos os dados oficiais divulgados pelo Inep em 2009, notamos que, apesar de um grande aumento do número de professores com formação profissional, ainda encontramos, principalmente nas regiões norte e nordeste, professores com formação apenas no ensino fundamental.

De acordo com dados do instituto, em março de 2009 o Brasil possuía 1.977.978 professores atuando na educação básica, sendo que destes: 0,63\% (12.480) possuía o ensino fundamental (6.701 na região nordeste), 31,56\% (624.320) o ensino médio e 67,80\% (1.341.178) o ensino superior.

Ainda que não possamos deixar de considerar as críticas realizadas por autores como Tanuri (2000) e Saviani (2009), ao observarmos o movimento em relação à formação inicial de professores no Brasil, podemos perceber algumas mudanças desde as primeiras iniciativas legais. Progressivamente, há uma maior organização das propostas de formação a partir da criação de diferentes espaços destinados à sua realização. Esses espaços, a princípio reduzidíssimos, vão aumentando à medida que crescem também as matrículas, principalmente nos primeiros anos do ensino fundamental, e vão também se aprimorando em suas ações. Ampliam-se ainda as exigências para o exercício do magistério nos diferentes níveis de ensino. Esse processo de aprimoramento é importante, ainda que não tenha se traduzido em realidade para todos os sistemas do país. Essas mudanças não ocorrem de maneira contínua e linear; caracterizam-se por momentos de descontinuidade, rupturas e novos avanços, sempre de maneira paralela às mudanças sociais e econômicas que marcam nossa realidade.

Esse é um breve panorama da formação de professores no Brasil ao longo de sua história, principalmente no que diz respeito à educação básica. A seguir apresentaremos algumas considerações sobre a formação dos professores para a educação especial, considerando as indicações legais, alguns dados atuais e discussões recentes sobre a problemática.

\subsection{A Formação Docente em Educação Especial}


Inicialmente, a formação de professores de educação especial no Brasil deu-se em cursos de nível médio ( $2^{\circ}$ grau), tendo seu início na década de 1950 e ocorrendo em diferentes estabelecimentos.

Ao fazermos uma retrospectiva histórica sobre a formação de professores para a Educação Especial no Brasil, vamos verificar que os primeiros cursos eram em nível médio, cuja carga horária variava muito uma vez que eram cursos intensivos que reuniam professores de vários estados. A história registra que tais cursos eram ministrados nos estabelecimentos Federais, Instituto Nacional de Educação de Surdos (INES-RJ) e Instituto Benjamim Constant (IBC-RJ). (ALMEIDA, 2004, p. 1)

No estado de São Paulo, segundo Mazzotta (1993), o primeiro curso regular de formação de professores para a educação especial teve início no Instituto de Educação Caetano de Campos, antiga Escola Normal Caetano de Campos.

A formação em nível médio, que perdurou até o final dos anos 60, ocorria, no caso de São Paulo, em cursos de especialização, ofertados pelos institutos de educação, com duração de um ano, tendo como exigência para ingresso a formação de professor primário.

Nesse período, Mazzotta (1993) destaca duas tendências adotadas pela formação, uma tendência educacional, que caracterizou os cursos para ensino de deficientes auditivos e deficientes visuais e outra, médico-pedagógica, que se evidenciava no ensino de deficientes físicos e mentais e caracterizava-se pelo aspecto terapêutico e tecnicista.

No início dos anos 70, a formação de professores de educação especial é elevada do nível médio ao superior, buscando a maior especialização dessa modalidade de educação. A partir dessa determinação, os cursos de pedagogia passam a oferecer a habilitação em Educação Especial. Entretanto, no início não havia uma orientação quanto ao currículo mínimo a ser oferecido, o que só veio a acontecer em 1975, a partir das indicações do Conselho Federal de Educação (CFE) nº 67/75 e nº 71/76, conforme Mazzotta (1993):

Como desdobramento da Indicação Básica CFE nº 67/75, a formação superior de professores para Educação Especial é definida aí por um currículo que inclui uma parte comum e outra diversificada.

$\mathrm{Na}$ parte comum incluem-se as disciplinas da formação pedagógica das licenciaturas, já que o sentido dado nas Indicações $n^{\circ}$ 68/75 e no 71/76 é o de especializar o professor já licenciado para início da escolarização. [...] A parte diversificada constitui-se das matérias específicas para as quatro áreas disciplinadas: I - Deficientes da Audiocomunicação [...]; II - Deficientes Físicos 
[...]; III - Deficientes Mentais [...]; e IV - Deficientes da Visão. (MAZZOTTA, 1993, p. 75-77, grifos do autor)

Apesar de, em São Paulo, ter-se instalado, já em 1972, pela Faculdade Pestalozzi de Ciências, Educação e Tecnologia, o primeiro curso de formação de professores de educação especial em nível superior, o mesmo não ocorreu em todo o país. No caso do Paraná, por exemplo, data da década de 90 a criação das primeiras habilitações em educação especial nos cursos de pedagogia, uma na Universidade Estadual do Centro-Oeste (UNICENTRO), em 1996, e outra na Universidade Federal de Ponta Grossa (IFPG), em 1998, conforme Almeida (2004). Esse exemplo ilustra a situação de desigualdade vivida pela educação nas diferentes regiões do país, como já foi comentado ao apresentarmos os dados relativos à formação de professores segundo o censo escolar de 2009.

Ainda em relação ao estado de São Paulo, Mazzota (1993) apresenta um quadro em que relaciona os estabelecimentos de ensino superior com habilitação específica em área de educação especial, no curso de pedagogia, a partir do ano de 1972.

\begin{tabular}{|c|c|c|c|c|c|c|}
\hline \multirow{2}{*}{$\begin{array}{l}\mathrm{N}^{\circ} \text { de } \\
\text { ordem }\end{array}$} & \multirow[t]{2}{*}{ Estabelecimento de Ensino Superior } & \multicolumn{4}{|c|}{ Área de Ed. Especial } & \multirow{2}{*}{$\begin{array}{c}\text { Ano de } \\
\text { Instalação }\end{array}$} \\
\hline & & $\mathrm{DA}^{5}$ & DF & DM & DV & \\
\hline 01 & $\begin{array}{l}\text { Faculdade Pestalozzi de C. Ed. e Tec. de } \\
\text { Franca (atual UNIFRAN) }\end{array}$ & \multicolumn{4}{|c|}{$\mathrm{x}$} & 1972 \\
\hline 02 & Universidade Mackenzie - Capital & \multicolumn{4}{|c|}{$\mathrm{x}$} & 1973 \\
\hline 03 & Pontifícia Univ. Católica de São Paulo & $\mathrm{x}$ & & & & 1973 \\
\hline 04 & $\begin{array}{l}\text { Faculdades Metropolitanas Unidas - } \\
\text { Capital }\end{array}$ & $x$ & & & & 1973 \\
\hline 05 & Pontifica Univ. Católica - Campinas & \multicolumn{4}{|c|}{$\mathrm{x}$} & 1975 \\
\hline 06 & $\begin{array}{l}\text { Faculdade "Auxilium" de Fil. C. e } \\
\text { Letras - Lins }\end{array}$ & \multicolumn{4}{|c|}{$\mathrm{x}$} & 1976 \\
\hline 07 & Univer. de Mogi das Cruzes & $\mathrm{x}$ & & & & 1976 \\
\hline 08 & $\begin{array}{l}\text { Univer. Estadual Paulista "Julio de } \\
\text { Mesquita Filho" - UNESP - "Campus" } \\
\text { de Marília }\end{array}$ & $\mathrm{x}$ & $\mathrm{x}$ & $\mathrm{x}$ & $\mathrm{x}$ & $1977(*)$ \\
\hline 09 & $\begin{array}{l}\text { Univer. Metodista de Piracicaba - } \\
\text { UNIMEP - Piracicaba }\end{array}$ & & & $\mathrm{x}$ & & 1977 \\
\hline
\end{tabular}

${ }^{5}$ DA : Deficiência Auditiva; DM: Deficiência Mental; DV: Deficiência Visual e DF: Deficiência Física 


\begin{tabular}{|c|c|c|c|c|c|}
\hline 10 & Universidade de Taubaté & $\mathrm{X}$ & $\mathrm{x}$ & & 1978 \\
\hline 11 & Centro de Est. Sup. do Carmo - Santos & $\mathrm{X}$ & $\mathrm{x}$ & $\mathrm{x}$ & 1979 \\
\hline 12 & $\begin{array}{l}\text { Faculdade de Fil. Ciências e Letras de } \\
\text { Jaú }\end{array}$ & & $\mathrm{x}$ & & 1981 \\
\hline 13 & Univer. de São Paulo - Capital & & $\mathrm{x}$ & $\mathrm{x}$ & 1983 \\
\hline \multirow[t]{2}{*}{14} & UNESP - "Campus" de Araraquara & & $\mathrm{x}$ & & 1986 \\
\hline & Total & 6 & 11 & 3 & \\
\hline
\end{tabular}

(*) O “Campus" de Marília da UNESP instalou, em 1977, as Habilitações em DM e DV; em 1980, a Habilitação em DA; em 1989, a Habilitação em DF.

(MAZZOTTA, 1993 p. 104)

Além das formações em nível médio e superior, vamos encontrar ainda cursos de especialização (lato-sensu), como alternativa para a formação de professores de educação especial.

Assim, conforme nos mostra Almeida (2004), vamos encontrar em 2001, em relação à formação de professores para educação especial no Brasil, a seguinte situação:

1. Formação inicial em nível médio:

- Professores normalistas habilitados em Educação Especial para determinadas áreas específicas, como DA, DM, DV, DF nos cursos de Estudos Adicionais;

- Professores normalistas habilitados em Educação Especial por meio de cursos de "especialização" promovidos pelas secretarias de Estado de Educação e Institutos de Educação (INES/RJ e IBC/RJ).

2. Formação Inicial em nível superior:

- Professores Habilitados em Educação Especial (para determinadas áreas específicas: DM, DA, DV, DF) nos cursos de Pedagogia;

- Professores licenciados somente em Educação Especial, que é o caso da Universidade Federal de Santa Maria (RS);

- Professores especializados em cursos de pós-graduação (especialização "latosensu"), mestrado e doutorado (GOTTI, 2001).

3. Formação continuada

- Professores licenciados em qualquer área do conhecimento (Português, Matemática, etc) "especializados" por meio de cursos de aperfeiçoamento em Educação Especial, promovidos por Instituições de Ensino Superior ou por Secretarias de Educação;

- Professores (geralmente com formação em magistério de nível médio) capacitados por meio de cursos de atualização promovidos por Instituições de Ensino Superior, Institutos de Educação, Secretarias de Educação; 
- Professores (com formação de nível médio ou superior) atuando com alunos especiais sem nenhum curso específico na área de Educação Especial (GOTTI, 2001) $)^{6}$ (ALMEIDA, 2004, p. 2)

Diante da situação exposta acima, concordamos com as preocupações de Saviani (2009) ao avaliar a falta de orientações claras sobre a formação de professores de educação especial. De acordo com o autor:

[...] no que se refere à formação de professores para atuar na Educação Especial a questão permanece em aberto. Com efeito, o lugar onde esse tipo de formação poderia ser contemplado em sua especificidade seria o curso de Pedagogia. Entretanto, a Resolução CNE/CP 1, de 2006, que definiu as diretrizes curriculares nacionais para o curso de Pedagogia toca na questão da Educação Especial de passagem e apenas duas vezes. (SAVIANI, 2009, p. 153)

Essa situação fica ainda mais preocupante quando analisamos os dados apresentados pelo Inep, relativos ao censo escolar de 2005. É importante ressalvar que após esse ano a informação sobre o nível de formação dos professores, como apresentada, deixou de constar dos dados do Inep, pelo menos até 2009, dificultando avaliar as mudanças ocorridas nos últimos anos.

\section{FUNÇÕES DOCENTES}

Educação Especial

2.19 - Número de Funções Docentes com e sem Curso Específico na Educação Especial, por Nível de Formação, segundo a Região Geográfica e a Unidade da Federação, em 30/3/2005

\begin{tabular}{|c|c|c|c|c|c|c|c|c|c|c|c|}
\hline \multirow{4}{*}{$\begin{array}{c}\text { Unidade } \\
\text { da } \\
\text { Federação }\end{array}$} & \multicolumn{11}{|c|}{ Funções Docentes na Educação Especial } \\
\hline & \multirow{3}{*}{ Total } & \multicolumn{5}{|c|}{ Com Curso Específico } & \multicolumn{5}{|c|}{ Sem Curso Específico } \\
\hline & & \multirow{2}{*}{ Total } & \multicolumn{2}{|c|}{ Fundamental } & \multirow{2}{*}{$\begin{array}{c}\text { Médio } \\
\text { Completo }\end{array}$} & \multirow{2}{*}{$\begin{array}{l}\text { Superior } \\
\text { Completo }\end{array}$} & \multirow{2}{*}{ Total } & \multicolumn{2}{|c|}{ Fundamental } & \multirow{2}{*}{$\begin{array}{c}\text { Médio } \\
\text { Completo }\end{array}$} & \multirow{2}{*}{$\begin{array}{l}\text { Superior } \\
\text { Completo }\end{array}$} \\
\hline & & & Incompleto & Completo & & & & Incompleto & Completo & & \\
\hline Brasil & 51.009 & 39.350 & 28 & 116 & 11.762 & 27.444 & 11.659 & 54 & 114 & 5.197 & 6.294 \\
\hline
\end{tabular}

Fonte: BRASIL, Inep. Censo Escolar 2005.

Como podemos perceber, apesar das discussões ocorridas ao longo dos anos a respeito da formação adequada para os professores que atuam na educação especial, particularmente com a

\footnotetext{
${ }^{6}$ GOTTI, M. O Ensino Superior: Políticas, propostas e demanda. Anais do XX Congresso Nacional das APAEs, I Fórum Nacional das APAEs: As APAEs e o novo milênio - Passaporte para a cidadania (PP. 247-270). Brasília: Federação Nacional das APAEs, 2001.
} 
indicação feita no Parecer do CNE/CEB nº 17/2001, citada anteriormente, a situação ainda é alarmente e estamos muito longe de atingir os patamares desejados.

No estado de São Paulo, de acordo com a deliberação do Conselho Estadual de Educação (CEE) n ${ }^{\circ} 94$ de dezembro de 2009 - que estabelece as normas, no sistema de ensino do estado, para a formação de professores, em nível de especialização, que realizam o atendimento a crianças com necessidades educacionais especiais -, os cursos oferecidos pelas universidades, centros universitários e institutos de ensino, tanto dos sistemas estadual quanto federal, deverão ter "carga horária mínima de 600 horas - a serem oferecidas durante um ano letivo - das quais $500 \mathrm{~h}$ dedicadas a atividades teóricas e/ou práticas e 100 h a estágio supervisionado" (SÃO PAULO, 2009).

Ainda segundo a deliberação, as 500 h destinadas a atividades teóricas e/ou práticas deverão ser distribuídas em:

I - tronco comum de formação básica de 200 horas, compreendendo os fundamentos filosóficos, pedagógicos e científicos da educação inclusiva e especial, bem como a inserção da formação na perspectiva histórico-social brasileira;

II - parte diversificada de, no mínimo 300 horas, dedicadas ao conhecimento e prática dos processos técnico-metodológicos relacionados à educação de crianças com necessidades especiais, em apenas um das áreas abrangidas pelo curso (deficiências - intelectual, visual, auditiva, física - transtornos globais do desenvolvimento, altas habilidades). (SÃO PAULO, 2009)

Essa é, no estado de São Paulo, a orientação legal mais recente sobre a formação dos professores especializados. É importante que nos próximos anos seja acompanhada a formação de professores no estado para verificarmos os desdobramentos da deliberação e a adequação dos diferentes espaços formativos às suas diretrizes.

Cabe destacar aqui que a deliberação paulista, ao ampliar para 600 horas a carga horária dos cursos de especialização (que, até então, organizavam-se com carga horária de 360 ou 420 horas) e estabelecer a parte diversificada de 300 horas em apenas uma área, aponta um caminho diferente da proposta de formação de professores para o atendimento educacional especializado oferecida pelo MEC, por meio da Secretaria de Educação Especial (Seesp), no âmbito da Universidade Aberta do Brasil (UAB). Tal proposta, estabelecida em 2007, compreende uma carga horária para o curso de especialização em 360 horas, abrangendo as áreas de deficiência 
mental (denominação utilizada na proposta de formação), deficiência física, pessoa com surdez, deficiência visual, transtorno global do desenvolvimento e altas habilidades/superdotação.

Permanece, portanto, como já apontado, a falta de um direcionamento claro que oriente as propostas de formação para os professores que objetivam atuar na educação especial.

\subsection{Formação continuada}

Buscando o aperfeiçoamento do exercício docente, encontraremos também na história da educação, em diferentes países, iniciativas no sentido de possibilitar aos professores a continuidade de seu processo formativo, desenvolvendo ainda mais seus conhecimentos e competências profissionais. É com esse objetivo que se organizam diferentes ações de formação continuada, entendidas aqui como aquelas que se realizam posteriormente à formação inicial.

Esse processo, associado às diferentes concepções de formação, poderá receber distintas denominações: formação em serviço, formação permanente, formação continuada, desenvolvimento profissional, entre outros.

Imbérnon (2010), ao referir-se às propostas de formação continuada desenvolvidas desde a década de 1970, apresenta três períodos distintos, compreendidos pelas décadas de 1980, 1990 e 2000. Antes dos anos 80, segundo o autor, as iniciativas em relação à formação continuada eram individuais, primando-se pela formação inicial e o saber dos professores era um "saber que durava toda a sua vida profissional".

Os anos de 1980 caracterizaram-se pela criação de programas, pelas universidades, baseados em modalidades de treinamento, organizados a partir da seleção, pelo formador, das atividades a serem desenvolvidas, marcados ainda pelo paradigma da racionalidade técnica.

Na década seguinte, apesar de ainda persistirem iniciativas marcadas pelo "treinamento", começaram a surgir modelos de formação alternativos. É uma época marcada por muitas mudanças, com a divulgação de textos, realização de encontros, jornadas e congressos, um modelo mais questionador, que favorece o desenvolvimento do professor investigador e da pesquisa-ação. 
O contexto social e as mudanças aceleradas no cenário mundial, a economia globalizada e a tecnologia marcam os anos 2000. Com eles uma crise na educação faz-se instalar, com a percepção de que a organização escolar já não é capaz de atender a população do século XXI. De acordo com Imbérnon (2010), esses fatores levaram a uma estagnação em relação ao grande movimento da década passada. A formação continuada é marcada por um movimento em que o formador caracteriza-se por ser aquele que diagnostica os obstáculos à formação. $\mathrm{O}$ autor sintetiza, no quadro que se segue, as características principais desses períodos, relacionando o conceito de conhecimento e o de formação.

\begin{tabular}{|c|c|c|c|}
\hline Anos & $\begin{array}{l}\text { Formas de ver o } \\
\text { conhecimento } \\
\text { formador nos } \\
\text { professores }\end{array}$ & $\begin{array}{l}\text { Formas de ver a } \\
\text { formação dos } \\
\text { professores }\end{array}$ & Metáforas \\
\hline$\ldots 1980 \ldots$ & $\begin{array}{l}\text { Uma informação } \\
\text { científica, cultural ou } \\
\text { psicopedagógica para } \\
\text { transmitir. }\end{array}$ & $\begin{array}{l}\text { Um produto assimilável } \\
\text { de forma individual, } \\
\text { mediante conferências } \\
\text { ou cursos ditados. }\end{array}$ & $\begin{array}{l}\text { Metáfora do produto } \\
\text { que se deve aplicar } \\
\text { nas salas de aula. } \\
\text { Época de busca de } \\
\text { receitas. A formação } \\
\text { "salva tudo". }\end{array}$ \\
\hline$\ldots 1990 \ldots$ & $\begin{array}{l}\text { O desenvolvimento de } \\
\text { conhecimentos, } \\
\text { habilidades, destrezas e } \\
\text { atitudes profissionais } \\
\text { para mudar as salas de } \\
\text { aula. }\end{array}$ & $\begin{array}{l}\text { Um processo de } \\
\text { assimilar estratégias, } \\
\text { para mudar os esquemas } \\
\text { pessoais e práticos da } \\
\text { interpretação dos } \\
\text { professores, mediante } \\
\text { seminários e oficinas. }\end{array}$ & $\begin{array}{l}\text { Metáfora do processo. } \\
\text { Época curricular que } \\
\text { inunda tudo. }\end{array}$ \\
\hline$\ldots 2000 \ldots$ & $\begin{array}{l}\text { Compartilhar } \\
\text { significados no contexto } \\
\text { educacional para mudar } \\
\text { as instituições } \\
\text { educacionais. }\end{array}$ & $\begin{array}{l}\text { Criação de espaços e } \\
\text { recursos para construir } \\
\text { aprendizagem, mediante } \\
\text { projetos de inovação e } \\
\text { intercâmbio nas escolas. } \\
\text { Processos de prática } \\
\text { reflexiva. }\end{array}$ & $\begin{array}{l}\text { Metáfora da } \\
\text { construção. Época de } \\
\text { novas redes de } \\
\text { formação presenciais } \\
\text { e virtuais. }\end{array}$ \\
\hline $\begin{array}{l}\text {...Rumo } \\
\text { ao futuro } \\
\text { (ou ao } \\
\text { desejado) }\end{array}$ & $\begin{array}{l}\text { Construção coletiva com } \\
\text { todos os agentes sociais, } \\
\text { para mudar a realidade } \\
\text { educativa e social. }\end{array}$ & $\begin{array}{l}\text { Elaboração de projetos } \\
\text { de transformação, com } \\
\text { a intervenção da } \\
\text { comunidade, e } \\
\text { pesquisas sobre a } \\
\text { prática. }\end{array}$ & $\begin{array}{l}\text { Metáfora da } \\
\text { subjetividade, da } \\
\text { intersubjetividade, do } \\
\text { dialogismo. Época de } \\
\text { novas alternativas e } \\
\text { participação da } \\
\text { comunidade. }\end{array}$ \\
\hline
\end{tabular}

(IMBÉRNON, 2010, p.24 ). 
É fundamental que se perceba a formação inicial e a continuada como partes de um processo único, que deve ocorrer durante toda a vida profissional. De acordo com Nóvoa (2001):

Durante muito tempo, quando nós falávamos em formação de professores, falávamos essencialmente da formação inicial do professor. Essa era a referência principal: preparavam-se os professores que, depois, iam durante 30, 40 anos exercer essa profissão. Hoje em dia, é impensável imaginar esta situação. Isto é, a formação de professores é algo, como eu costumo dizer, que se estabelece num continuum. Que começa nas escolas de formação inicial, que continua nos primeiros anos de exercício profissional. (NÓVOA, 2001)

A LDB 9394/96 faz referência à garantia de formação continuada no art. 63 ao prever "III - programas de educação continuada para os profissionais de educação dos diversos níveis” e ainda no Art. 67, que inclui a formação continuada como forma de valorização dos profissionais da educação, indicando aos sistemas de ensino a necessidade de assegurar, em seus estatutos e planos de carreira do magistério público "II - aperfeiçoamento profissional continuado, inclusive com licenciamento periódico remunerado para esse fim" (BRASIL, 1996).

Num momento em que estão cada vez mais presentes os debates sobre a busca de melhoria da qualidade de ensino, a formação continuada, assim como a formação inicial, adquire um destaque especial.

Temos visto que os avanços na legislação educacional, apesar de fundamentais, não tem sido suficientes para garantir as mudanças desejadas nos espaços escolares e nas práticas docentes. Dessa forma, investir nos professores (em formação e em exercício), como agentes de mudança torna-se uma ação essencial para que as novas propostas, em especial aquelas que se referem ao atendimento aos alunos com necessidades educacionais especiais, efetivem-se no cotidiano escolar.

Assim compreendida a importância da formação continuada, fica evidente a necessidade de nos debruçarmos sobre as propostas atualmente desenvolvidas, sob o risco de desenvolvermos junto aos professores ações que não propiciem mudanças em suas concepções e práticas e, por consequência, nos espaços escolares.

De acordo com Candau (1996), a preocupação com a formação continuada não é algo novo, sendo possível identificar uma perspectiva "clássica" de formação continuada de professores que tem a universidade como local privilegiado para sua realização, seja por meio de cursos de aperfeiçoamento, especialização, pós-graduação - lato e stricto sensu - seja por 
convênios estabelecidos com as secretarias de educação para a realização de cursos, utilizando diferentes estratégias (mais recentemente, o ensino à distância), ou ainda pela presença de profissionais das universidades em cursos promovidos pelas secretarias de educação e/ou pelo MEC.

A autora, ao analisar essa proposta de formação baseada no saber desenvolvido pela universidade, propõe alguns questionamentos sobre as concepções que a embasam. Assim, questiona a dicotomia entre teoria e prática, que atribui à universidade a primazia sobre o desenvolvimento do conhecimento, deixando para os professores o papel de meros reprodutores e executores das propostas da universidade. Refletindo sobre o processo contínuo de construção do conhecimento, pergunta se esse também não pode se dar na prática pedagógica cotidiana, numa perspectiva reflexiva e crítica.

A valorização da experiência profissional para a produção do conhecimento pode ser compreendida dentro do paradigma de crescimento, conforme conceituado por Éraut ${ }^{7}$ (1985, apud Silva, 2000, p. 30), que propõe tomar a experiência dos professores e sua reflexão sobre ela como base para o conhecimento e crescimento profissional, alertando para o fato de que apenas a reflexão sobre a experiência não é suficiente para promover o desenvolvimento desejado, devendo aliar-se ao tempo e a instrumentos adequados para sua efetivação. Nessa perspectiva, o conteúdo das formações deve ter por base as necessidades e preocupações dos professores.

Antes de nos aprofundarmos um pouco mais nesse modelo de formação, vamos relacionar os outros paradigmas definidos por Éraut (1985, apud Silva, 2000), uma vez que parecem abarcar as propostas de formação continuada que se desenvolvem no cenário atual.

Além do paradigma do crescimento, o autor propõe ainda o paradigma do déficit, segundo o qual a formação continuada teria como característica preencher as lacunas da formação inicial, o que pressupõe a sua limitação e a consequente necessidade de fornecer aos professores as competências necessárias à sua atuação. Nessa proposta as decisões são tomadas pelo órgão central e mesmo os formadores não têm poder de decisão sobre a seleção dos conteúdos.

De acordo com o paradigma da mudança, os sistemas educativos necessitam ser revistos no decorrer do tempo considerando as mudanças no meio social. Assim, a formação dos professores visaria ao acompanhamento dessas inovações, considerando que, sozinhos, eles não

\footnotetext{
${ }^{7}$ ÉRAUT, M. Inservice Teacher Education.1985. In: DUNKLIN (ed). The International Encyclopedia of Teaching and Teacher Education. Oxford: Pergamon Press.
} 
são capazes de efetivá-las. Como exemplo, podemos mencionar a proposta sócio-construtivista presente nas orientações de diferentes sistemas de ensino.

Por último, temos o paradigma da resolução de problemas, em que o autor situa aquelas iniciativas que visam à busca de respostas para questões encontradas no cotidiano de cada escola, exercendo os professores papel fundamental na avaliação e propostas de encaminhamento. Apesar de centrada na escola, pode ocorrer em outras instâncias, como centros de formação.

Partindo da reflexão dos professores sobre o cotidiano escolar, podemos encontrar um paralelo com o paradigma de crescimento, apesar de, nesse caso, as questões restringirem-se a problemas que emergem na escola ou na sala de aula.

Em nossa prática profissional temos presenciado momentos em que propostas de formação características dos quatro paradigmas têm se feito presentes, respondendo a diferentes necessidades e objetivos do sistema de ensino.

Retomando as questões colocadas pela prática reflexiva do professor, acreditamos ser importante melhor conceitualizá-la, uma vez que essa perspectiva nos parece representar algo mais recente nas propostas de formação que temos acompanhado.

A formação do professor reflexivo, conforme compreendida por Zeichner (1993), compreende três características:

\begin{abstract}
Em primeiro lugar, na minha perspectiva sobre a prática do ensino reflexivo, a atenção do professor está tanto virada para dentro, para a sua própria prática, como para fora, para as condições sociais nas quais se situa essa prática. [...] Uma segunda característica do meu ponto de vista sobre a prática reflexiva é a sua tendência democrática e emancipatória e a importância dada às decisões do professor quanto a questões que levam a situações de desigualdade e injustiça dentro da sala de aula. [...] Uma terceira característica da minha opinião sobre a prática do ensino reflexivo é o compromisso com a reflexão prática social. Existe aqui a tentativa de construir comunidades de aprendizagem, nas quais os professores apóiam e sustentam o crescimento uns dos outros. (ZEICHNER, 1993, p. 25-26)
\end{abstract}

Um ponto que parece se destacar nas afirmações de Zeichner (1993) sobre a formação do professor reflexivo é o seu compromisso com a questão social, não só no sentido de incluí-la no entendimento das questões vivenciadas no espaço escolar, como na compreensão de sua prática fundamentalmente política - e seu compromisso com as mudanças institucionais e sociais. 
O autor alerta ainda para algumas distorções pelas quais tem passado, nos Estados Unidos, o conceito de formação reflexiva que, muitas vezes, favorecem a manutenção de um estado de subserviência.

$\mathrm{O}$ primeiro ponto refere-se às indicações para que se reproduzam iniciativas desenvolvidas por outros professores, desconsiderando-se as teorias e saberes que embasam a prática dos profissionais a serem imitados e daqueles que pretendem reproduzí-las.

Do mesmo modo, alguns programas de formação limitam-se a indicar uma reflexão sobre as estratégias de ensino, desconsiderando a importância de se questionar também seus objetivos. As decisões sobre o que ensinar, a quem e porque são delegadas a outras pessoas, o que leva os professores a desenvolverem uma atividade eminentemente técnica.

Outro ponto importante é o foco na prática do professor, sua sala de aula e seus alunos. Apesar de fundamental, esse foco não pode excluir as condições sociais do ensino, que influenciam não só a ação dos professores como suas condições de trabalho, a organização escolar e seus alunos.

Essas considerações reforçam a idéia de que os professores são os atores principais em qualquer projeto que objetive uma mudança nas concepções e práticas escolares.

Nessa concepção de formação, dois aspectos parecem concordar com as observações de Candau (1996): a referência à escola como locus da formação continuada e a valorização do saber docente.

Em relação ao primeiro aspecto, fica evidente que é no cotidiano da escola que o professor organiza, reorganiza e aprimora seus conhecimentos e sua prática, desenvolvendo-se aí boa parte de sua formação. Compreender esse fato nos leva a pensar nas condições que precisam ser ofertadas para que nesse espaço possa se aprimorar a formação do professor, principalmente por meio de ações construídas no coletivo.

A valorização do saber docente também é um aspecto relevante que precisa ser considerado nas propostas de formação. É a partir desse saber, construído no cotidiano escolar e em suas experiências, que o professor vai avaliar e validar as propostas de formação oferecidas, além das mudanças implantadas pelos sistemas de ensino.

Um último aspecto destacado pela autora vem complementar as reflexões de Zeichner (1993) e diz respeito ao ciclo de vida profissional dos professores. Para ela é fundamental que se leve em conta o momento da carreira em que o professor está ao se formularem propostas de 
formação, considerando que suas necessidades, dúvidas e inquietações são diferentes de acordo com seu momento profissional. Candau (1996), citando Huberman ${ }^{8}$, diz que:

O autor identifica cinco etapas básicas, que não devem ser concebidas de uma forma estática e linear e sim em relação dialética: a entrada na carreira, etapa de "sobrevivência e descoberta", a fase de estabilização, momento de questionamento, de experimentação, de buscas plurais; o momento de serenidade e distância afetiva e/ou de conservadorismo e lamentações e, finalmente atinge-se um momento de desinvestimento, de recuo e interiorização, característico do final da carreira profissional. $\mathrm{O}$ ciclo profissional é de um processo complexo no qual interferem múltiplas variáveis. (CANDAU, 1996, p. 149)

Como podemos perceber, tão complexas quanto as questões relativas à formação inicial dos professores são as que dizem respeito à sua formação continuada. É imprescindível, caso se deseje alcançar melhores níveis de ensino para todos os alunos, que sejam realizados investimentos por parte dos governos federal, estadual e municipal, não só de ordem financeira, mas também estrutural, para que se efetivem políticas de formação e valorização da profissão docente.

Do mesmo modo, é importante que se avaliem as propostas de formação continuada desenvolvidas pelos diferentes sistemas de ensino, objetivando compreender a visão de seus gestores sobre a profissão docente, bem como sobre a instituição escolar e sua função social.

Finalizando, é importante ressaltar que o destaque dado aqui aos processos de formação continuada de maneira nenhuma representa a valorização desta em detrimento da formação inicial, que carece dos mesmos investimentos e preocupações e que representa momento privilegiado da formação de professores. Entretanto, justifica-se por representar o enfoque dado por nossa pesquisa, que objetiva estudar as propostas de formação continuada implementadas por um sistema municipal de ensino, bem como as necessidades formativas indicadas por um grupo de professores atuando nesse mesmo sistema, como veremos no próximo capítulo.

\footnotetext{
${ }^{8}$ HUBERMAN, M. La vie des enseignants: evolution et bilan de une profession. Paris, Delachaux et Niestlé, 1989.
} 


\subsection{Metodologia de Análise}

Como método de tratamento das entrevistas, utilizamos a análise de conteúdo, conforme definida por Bardin (1977).

Um conjunto de técnicas de análise das comunicações visando obter por procedimentos sistemáticos e objectivos de descrição do conteúdo das mensagens indicadores (quantitativos ou não) que permitam a inferência de conhecimentos relativos às condições de produção/recepção (variáveis inferidas) destas mensagens. (BARDIN, 1977 p. 44)

Dentre o conjunto de técnicas de análise de conteúdo, utilizamos aquela que, de acordo com essa autora, é a mais antiga e mais utilizada: a análise por categorias. Após sucessivas leituras dos textos, foram se estabelecendo algumas categorias com base em agrupamentos e reagrupamentos analógicos.

De acordo com Triviños (1987), ao proceder a análise de conteúdo, três etapas fundamentais devem ser seguidas:

- a pré-análise (organização do material);

- a descrição analítica, que começa na pré-análise, constituindo a primeira categorização;

- a interpretação inferencial, que compreende uma maior reflexão sobre as leituras realizadas.

Desse modo, as entrevistas, gravadas com a autorização dos entrevistados, foram transcritas, buscando-se garantir a fidelidade das falas dos professores. O texto foi submetido a uma segunda leitura, comparando-se à gravação das entrevistas e então finalizado. Após sucessivas leituras de cada uma e do conjunto de entrevistas, foram destacadas as unidades de registro, definidas por Bardin (1977) como: 
[...] a unidade de significação a codificar e corresponde ao segmento de conteúdo a considerar como unidade de base, visando a categorização e a contagem frequencial. A unidade de registro pode ser de natureza e de dimensões muito variáveis. (BARDIN, 1977, p. 130)

Para melhor compreensão dessas significações, ampliamos essas unidades, criando unidades de contexto.

A unidade de contexto serve de unidade de compreensão para codificar a unidade de registro e corresponde ao segmento da mensagem, cujas dimensões (superiores às da unidade de registro) são óptimas para que se possa compreender a significação exacta da unidade de registro. (BARDIN, 1977, p. 133)

Concluindo essa etapa da análise de conteúdo, apresentamos os temas e categorias relacionadas e, em seguida, procederemos a sua análise.

\subsection{Apresentação dos Dados das Entrevistas}

Quadro 1 - Identificação dos entrevistados em relação ao tipo, tempo, local da formação inicial e outras formações obtidas após a graduação.

\begin{tabular}{|c|c|c|c|c|}
\hline 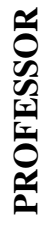 & $\begin{array}{l}\text { Tempo de } \\
\text { formado } \\
\text { (anos) }\end{array}$ & Tipo de formação inicial & Local da formação & Outras formações \\
\hline A & 9 & $\begin{array}{c}\text { Habilitação em Educação } \\
\text { Especial / DM }\end{array}$ & $\begin{array}{c}\text { Fundação Santo } \\
\text { André }\end{array}$ & Psicanálise \\
\hline $\mathbf{B}$ & 10 & $\begin{array}{c}\text { Habilitação em Educação } \\
\text { Especial / DM }\end{array}$ & UNILUS Santos & Psicopedagogia \\
\hline C & 25 & $\begin{array}{c}\text { Habilitação em Educação } \\
\text { Especial / DM }\end{array}$ & $\begin{array}{l}\text { Universidade } \\
\text { Mackenzie }\end{array}$ & Psicopedagogia \\
\hline
\end{tabular}




\begin{tabular}{|c|c|c|c|c|}
\hline D & 8 & $\begin{array}{c}\text { Habilitação em Educação } \\
\text { Especial / DM }\end{array}$ & $\begin{array}{l}\text { Universidade } \\
\text { Mackenzie }\end{array}$ & - \\
\hline $\mathbf{E}$ & 20 & $\begin{array}{c}\text { Habilitação em Educação } \\
\text { Especial / DM }\end{array}$ & PUC Campinas & $\begin{array}{l}\text { Pós graduação em } \\
\text { Educação Especial }\end{array}$ \\
\hline $\mathbf{F}$ & 40 & $\begin{array}{l}\text { Formação de professores de } \\
\text { excepcionais - APAE }\end{array}$ & APAE & $\begin{array}{l}\text { Pedagogia Habilitação em } \\
\text { DM Habilitação em DV }\end{array}$ \\
\hline $\mathbf{G}$ & 7 & $\begin{array}{c}\text { Especialização em Educação } \\
\text { Especial }\end{array}$ & FMU & $\begin{array}{c}\text { Psicopedagogia Direito } \\
\text { Educacional Educação } \\
\text { Especial / DA }\end{array}$ \\
\hline $\mathbf{H}$ & 30 & $\begin{array}{l}\text { Habilitação e Especialização } \\
\text { em Educação Especial / DM }\end{array}$ & PUC Campinas & $\begin{array}{c}\text { Psicopedagogia } \\
\text { Sócio Psicomotricidade }\end{array}$ \\
\hline I & 23 & $\begin{array}{c}\text { Habilitação e Especialização } \\
\text { em Educação Especial / DM e } \\
\text { DV }\end{array}$ & $\begin{array}{l}\text { Universidade do } \\
\text { Carmo }\end{array}$ & Psicopedagogia \\
\hline $\mathbf{J}$ & 6 & Especialização em DM & PUC & - \\
\hline
\end{tabular}

Fonte: Entrevistas realizadas com professores de atendimento educacional especializado na cidade de São Bernardo do Campo/ SP pelo autor.

Quadro 2 - Identificação dos entrevistados em relação ao tempo de trabalho como professor especializado, tempo de serviço na rede municipal de São Bernardo do Campo, tempo de trabalho na sala de recursos do município, atuação em outras redes e outras experiências de trabalho.

\begin{tabular}{|c|c|c|c|c|c|}
\hline Professor & $\begin{array}{c}\text { Tempo de } \\
\text { trabalho como } \\
\text { professor } \\
\text { especializado } \\
\text { (anos) }\end{array}$ & $\begin{array}{c}\text { Tempo de } \\
\text { serviço na } \\
\text { prefeitura } \\
\text { municipal } \\
\text { (anos) }\end{array}$ & $\begin{array}{c}\text { Tempo de } \\
\text { trabalho em } \\
\text { sala de } \\
\text { recursos na } \\
\text { rede } \\
\text { municipal } \\
\text { (anos) }\end{array}$ & $\begin{array}{c}\text { Atuação em } \\
\text { outras } \\
\text { redes }\end{array}$ & $\begin{array}{c}\text { Experiência em outros } \\
\text { serviços de educação } \\
\text { especial }\end{array}$ \\
\hline A & 6 & 6 & 5 & Não & Escola especial/SBC \\
\hline B & 7 & 6 & 5 & Não & Escola especial/SBC \\
\hline C & 23 & 10 & 6 & Não & $\begin{array}{c}\text { Classe Especial/Rede } \\
\text { Estadual de SP }\end{array}$ \\
\hline
\end{tabular}




\begin{tabular}{|c|c|c|c|c|c|}
\hline D & 7 & 7 & 6 & Não & $\begin{array}{c}\text { Classe Especial/Rede } \\
\text { Estadual de SP }\end{array}$ \\
\hline $\mathbf{E}$ & 19 & 18 & 6 & Não & $\begin{array}{c}\text { Classe Especial/Rede } \\
\text { Estadual de SP } \\
\text { Escola Especial/SBC }\end{array}$ \\
\hline $\mathbf{F}$ & 40 & 16 e $6 *$ & 4 & Não & $\begin{array}{c}\text { APAE } \\
\text { Classe Especial / SBC }\end{array}$ \\
\hline G & 7 & 6 & 5 & Não & $\begin{array}{l}\text { Classe Especial/Rede } \\
\text { Estadual de SP }\end{array}$ \\
\hline H & 30 & 10 & 6 & Não & $\begin{array}{c}\text { Classe Especial/Rede } \\
\text { Estadual de SP Escola } \\
\text { Especial }\end{array}$ \\
\hline I & 21 & 15 & 5 & Não & $\begin{array}{l}\text { Classe Especial/Rede } \\
\text { Estadual de SP } \\
\text { Escola Especial/SBC }\end{array}$ \\
\hline $\mathbf{J}$ & 10 & 6 & 4 & Não & $\begin{array}{c}\text { APAE / SP } \\
\text { Escola Especial / SBC }\end{array}$ \\
\hline
\end{tabular}

* A professora ingressou na PMSBC, exercendo sua função por 16 anos, posteriormente se aposentou e ingressou novamente há 6 anos.

Fonte: Entrevistas realizadas com professores de atendimento educacional especializado na cidade de São Bernardo do Campo/ SP pelo autor.

\subsection{Síntese dos Temas e Categorias das Entrevistas}

Quadro 3 - Temas e categorias das entrevistas

\begin{tabular}{|c|c|}
\hline Temas/Categorias & $\begin{array}{l}\mathrm{N}^{0} \text { de professoras que os } \\
\text { referiram }\end{array}$ \\
\hline 1. Avaliação da proposta de trabalho & 10 \\
\hline - Organização / Estruturação do trabalho & 8 \\
\hline - Contexto / Interferências & 7 \\
\hline - Papel do professor da sala de recursos & 2 \\
\hline 2. Público atendido pela sala de recursos & 9 \\
\hline - Diversidade de público & 9 \\
\hline - Equívocos nos encaminhamentos & 3 \\
\hline 3. Formação & 10 \\
\hline - Referências gerais à formação & 4 \\
\hline - $\quad$ Formação inicial & 2 \\
\hline $\begin{array}{l}\text { - Formações externas, contratadas pela Secretaria Municipal de } \\
\text { Educação de São Bernardo do Campo }\end{array}$ & 10 \\
\hline
\end{tabular}


- Formação internas, sob a coordenação de profissionais da Equipe de Orientação Técnica da Secretaria Municipal de Educação de São Bernardo do Campo

- Propostas de formação - organização

- Propostas de formação - temas

9

4

10

Fonte: Entrevistas realizadas com professores de atendimento educacional especializado na cidade de São Bernardo do Campo/ SP pelo autor.

Como podemos ver no quadro acima, os três temas centrais que se relacionavam às questões propostas nas entrevistas subdividiram-se em categorias mais específicas, de acordo com as respostas dos entrevistados.

Nas próximas páginas cada tema será destacado, detalhando-se as categorias que se constituíram a partir das respostas.

\subsection{Síntese Descritiva das Entrevistas}

Quadro 4 - Categorias do tema Avaliação da proposta de trabalho

\begin{tabular}{|c|c|}
\hline Temas/Categorias & $\mathrm{N}^{\circ}$ de professoras que os referiram \\
\hline 1. Avaliação da proposta de trabalho & 10 \\
\hline - Organização / Estruturação do trabalho & 8 \\
\hline - Contexto / Interferências & 7 \\
\hline - Papel do professor da sala de recursos & 2 \\
\hline
\end{tabular}

Fonte: Entrevistas realizadas com professores de atendimento educacional especializado na cidade de São Bernardo do Campo/ SP pelo autor.

Ao se referirem à proposta de trabalho em salas de recursos, os professores destacaram três aspectos:

- A organização/estruturação do trabalho: a forma como esse serviço se organizou no município e como se deu o seu desenvolvimento nos últimos nove anos.

- Contexto/Interferências: o atendimento em sala de recursos se insere em um contexto maior, seja referindo-se à escola comum, onde se desenvolve, seja em relação à política de educação especial do município. Esse contexto interfere na maneira como o trabalho se desenvolve. 
- Papel do professor da sala de recursos: a forma como os professores percebem o seu papel dentro da escola comum e a política de inclusão no município.

Quadro 5 - Categorias do tema Público atendido pela sala de recursos

\begin{tabular}{|cl|c|}
\hline \multicolumn{1}{|c|}{ Temas/Categorias } & $\mathbf{N}^{\mathbf{0}}$ de professoras que os referiram \\
\hline 2. & Público atendido pela sala de recursos & 9 \\
\hline$\bullet$ & Diversidade de público & 9 \\
\hline$\bullet$ & Equívocos nos encaminhamentos & 3 \\
\hline
\end{tabular}

Fonte: Entrevistas realizadas com professores de atendimento educacional especializado na cidade de São Bernardo do Campo/ SP pelo autor.

O tema "público atendido pela sala de recursos" foi abordado pelos professores entrevistados sob dois aspectos:

- A diversidade do público: os professores afirmam que diferentes deficiências, quadros clínicos e questões de aprendizagem caracterizam os alunos que hoje são atendidos pelas salas de recursos do município.

- Equívocos nos encaminhamentos: alguns professores, avaliando a diversidade do público atendido, reconhecem haver distorções nas indicações realizadas pelas equipes escolares, que geram equívocos no sentido do encaminhamento de alunos que não se configuram como público da educação especial, uma vez que apresentam diferentes questões de aprendizagem.

QUADRO 6 - Categorias do tema Formação

\begin{tabular}{|c|c|}
\hline Temas/Categorias & $\begin{array}{l}\mathbf{N}^{\circ} \text { de professoras que } \\
\text { os referiram }\end{array}$ \\
\hline 3. Formação & 10 \\
\hline - Referências gerais à formação & 4 \\
\hline - $\quad$ Formação inicial & 2 \\
\hline $\begin{array}{l}\text { - Formações externas, contratadas pela Secretaria de Educação de São } \\
\text { Bernardo do Campo }\end{array}$ & 10 \\
\hline $\begin{array}{l}\text { - Formações internas, sob a coordenação de profissionais da própria } \\
\text { Secretaria de Educação de São Bernardo do Campo }\end{array}$ & 9 \\
\hline - $\quad$ Propostas de formação - organização & 4 \\
\hline - $\quad$ Propostas de formação - temas & 10 \\
\hline
\end{tabular}

Fonte: Entrevistas realizadas com professores de atendimento educacional especializado na cidade de São Bernardo do Campo/ SP pelo autor. 
Esse foi o tema que apresentou uma maior diversidade de categorias. Ao se referirem à formação, alguns professores retomaram desde sua formação inicial, passando pelas características do serviço de sala de recursos no município e pelas experiências de formação nos últimos anos.

- Referências gerais à formação: nessa categoria as afirmações dos professores dizem respeito à formação enquanto um investimento importante por parte do sistema, sem discriminar exatamente a que tipo ou que temas devem ser contemplados.

- Formação inicial: alguns professores, ao avaliarem o processo de formação, retomam a questão da formação inicial, indicando a sua relação com as demandas do serviço.

- Formações externas, contratadas pela Secretaria de Educação de São Bernardo do Campo: nessa categoria os professores referem-se às formações que foram contratadas pela Secretaria de Educação Municipal de São Bernardo, avaliando a sua relação com as necessidades do serviço.

- Formações internas, sob a coordenação de profissionais da própria Secretaria de Educação de São Bernardo do Campo: além das formações externas, a Secretaria de Educação, por meio dos profissionais do seu quadro técnico, vem oferecendo formações aos professores das salas de recursos. Durante as entrevistas os professores também se referiram a essas formações, avaliando sua pertinência em relação às demandas geradas pelo atendimento aos alunos.

- Propostas de formação - organização: as indicações de formação foram formuladas pelos professores entrevistados considerando a proposta e o público atendido nas salas de recursos do município. Foram divididas em duas categorias, sendo que esta primeira refere-se à maneira como as formações devem ocorrer.

- Propostas de formação - temas: os professores entrevistados indicaram aqui os temas que deveriam compor as formações a serem oferecidas pela Secretaria de Educação, juntamente com as indicações da categoria anterior; a indicação dos temas aponta para as necessidades formativas destacadas pelos próprios professores que atuam no serviço de salas de recursos. 


\subsection{Análise das Categorias das Entrevistas}

\subsubsection{Organização/Estruturação do trabalho}

Os professores, de modo geral, avaliam que a organização e estruturação do trabalho de sala de recursos no município têm atendido às necessidades dos alunos, contribuindo para o seu desenvolvimento. Ressaltam alguns aspectos, que definem como positivos nessa organização, como a professora $\mathrm{H}$, ao destacar a forma como, em 2005 , uma série de discussões, envolvendo os professores que constituíam o grupo de sala de recursos, estabeleceram diretrizes para o trabalho.

Ele se organizou com certa prudência, vamos dizer de aspectos, o que a gente achava importante, e o que eu acho importante em São Bernardo, ela escuta o professor. Nós fomos escutadas, nós nos reunimos periodicamente pra estar dando a nossa opinião do que nós sentimos e não foi taxativo, não foi ditador, "Não, é assim que tem que funcionar!". Então foi um processo, foi uma construção do que era e do que não era melhor. (professor $\mathrm{H}$ )

O fato de terem participado ativamente do processo de elaboração das diretrizes e orientações para o desenvolvimento do atendimento em sala de recursos é bastante valorizado pelos professores. Essa participação concorre para que a estruturação do trabalho seja bem avaliada, uma vez que ela retrata as opiniões e concepções dos professores, um aspecto que contempla a proposta de formação reflexiva.

Outro aspecto muito valorizado foi a possibilidade de trabalho junto ao professor da classe comum em que o aluno está matriculado, constituindo uma das ações do professor da sala de recursos, ao lado do atendimento ao aluno.

$\mathrm{Eu}$ creio que, assim, o atendimento que é feito em São Bernardo deveria até ser constituído como um atendimento modelo. Essa possibilidade do professor que faz o atendimento educacional especializado, vamos usar o nome atual AEE, para as crianças que estão na inclusão, estar muito perto do professor do regular, estar acompanhando na construção, né, contribui não só para aquele aluno que tenha o diagnóstico de NEE, mas com os outros, né. (professor C) 
A partir dessa organização e das características que o trabalho foi assumindo ao longo dos anos, desde 2000, os professores indicam uma evolução, tanto no que diz respeito aos aspectos estruturais quanto nas concepções que o embasam.

Olha, Edison, que acredito que assim, é um trabalho que ele foi evoluindo... tá, acho que assim, a gente não tinha uma estrutura bacana, essa estrutura tá começando, eu acho que a funcionar de forma mais positiva, quando eu falo estrutura eu falo desde você ter um lugar pra atender a você ter o material... (professor I)

Eu acho que a sala de recursos hoje, ela vem pra enriquecer as crianças que estão dentro da escola, crianças incluídas dentro da escola, tanto crianças com deficiência quanto as crianças com necessidades educacionais especiais. (professor A)

A análise dessa categoria indica que os professores apoiam a organização do serviço, sentindo-se participantes desse processo. Indicam que a sua estruturação tem atendido as necessidades dos alunos e apontam avanços nesse processo desde a implantação do serviço.

Apesar de não haver, a princípio, uma ligação direta dessa categoria com os objetivos do presente trabalho, julgamos que o posicionamento dos profissionais a respeito da organização do serviço pode interferir na maneira como avaliam as propostas de formação e as necessidades formativas que podem indicar, e que devem adequar-se ao trabalho que estão realizando. Consideramos que, ao indicarem uma concordância com a estruturação e as diretrizes do trabalho, os professores avaliam as propostas formativas sem o prejuízo que ocorreria em uma avaliação que indicasse discordância dos princípios. Ao referirem muitas críticas às concepções e estruturação do serviço, indicando não aprovarem as diretrizes estabelecidas pela Secretaria de Educação do município, os professores poderiam buscar nas formações formas de corrigir as distorções que indicassem nesse processo. Afirmando sua concordância com essa estrutura, as indicações e avaliações da formação apontarão aspectos que complementam o trabalho desenvolvido, estando de acordo com as diretrizes estabelecidas.

\subsubsection{Contexto/Interferências}


Os professores, ainda que estejam de acordo com a organização do serviço, reconhecem que alguns fatores relativos ao contexto mais amplo - organização do ensino regular, a política de educação especial e até mesmo a estrutura da unidade escolar onde desenvolvem suas atividades - interferem na organização do serviço.

[...] é participar da escola, não dividir, acho que essa é a nossa maior dificuldade, que por mais que a gente sabe que tá dentro [da escola], a gente ainda não se percebe fazendo parte, e não é só porque alguns professores não... às vezes a gente sente que é uma coisa maior que tá acontecendo e está até acontecendo na prefeitura, né [...]. (professor G) [...] e aí, nesse aspecto eu não sei muito como acontece a formação das equipes de gestão, porque o que a gente vê é... as equipes de gestão não entendem o trabalho da gente, então eles têm a expectativa também que a gente só atenda aluno, né. Então a gente fica nesse embate com elas. (professor D)

Dois fatores chamam a atenção nessas afirmações dos professores: o primeiro refere-se à falta de articulação entre a educação especial, mais especificamente entre o serviço de sala de recursos e as ações do ensino regular. A educação especial, que deveria transversalizar as diferentes áreas e modalidades de ensino, parece ocorrer paralelamente ao ensino fundamental, uma vez que, apesar do atendimento em sala de recursos ocorrer no município há nove anos, os professores apontam o desconhecimento, por parte das equipes gestoras, da proposta de trabalho e mesmo das concepções da educação especial. Os professores, apesar de participarem efetivamente do coletivo da escola, tendo ali sua sede administrativa, realizarem junto com os demais professores o horário de trabalho pedagógico coletivo (HTPC), as reuniões pedagógicas, a elaboração do projeto político pedagógico e todas as demais ações que envolvem o grupo da escola, não se percebem fazendo parte desse coletivo.

A expectativa de que o professor "só atenda aluno" parece refletir uma cisão entre o público do ensino regular e o da educação especial. Ao demandarem aos professores do AEE cada vez mais o atendimento direto aos alunos em detrimento do planejamento e discussão com os professores das classes comuns ou outras ações que envolvam os profissionais da escola, além de demonstrarem um desconhecimento das ações realizadas pelos professores especializados, as equipes gestoras parecem indicar que aqueles alunos encaminhados ao atendimento da sala de 
recursos são responsabilidade do professor da educação especial, cabendo a ele identificar e implementar as ações que poderão promover o desenvolvimento pedagógico dos alunos.

Além do contexto da escola, mais próximo ao professor, e da maneira como os gestores compreendem a ação da educação especial, por meio dos professores de sala de recursos, também são percebidas interferências da política instituída pela Secretaria Municipal de Educação. A forma como os diferentes serviços de educação especial estão organizados tem seu reflexo também nas ações e no estabelecimento do público da sala de recursos.

Eu acho que tá desorganizado, [referindo-se aos diferentes serviços da educação especial em São Bernardo do Campo]. Eu acho que tem muitos segmentos mesmo diferenciados. Acho que a proposta ainda não está clara, né. Eu acho que eles têm que definir melhor, seguir uma linha de inclusão... Por que é que foi até falado: é bolsa, é integrada [classe especial], é especial [escola], sala de recursos, é muita coisa junta. Não pode. (professor B)

Algumas diretrizes da Secretaria de Educação do município, que se refletem em processos internos de avaliação, também são apontadas como interferências que trazem prejuízos ao processo de inclusão dos alunos atendidos nas salas de recursos. Na opinião dos professores, o direcionamento dessas avaliações leva a equívocos que contrariam as diretrizes da educação inclusiva.

Ah, como a gente faz no final do ano, que essa menina [atendida na sala de recursos] é matriculada como tantos outros, e como é que a gente faz no final do ano quando lá na SEC [Secretaria de Educação e Cultura] uma listinha "Porcentagem de alunos alfabéticos e não alfabéticos"? Porque se o número for grande de não alfabéticos é porque os professores não trabalharam bem, é porque a escola não é legal. (professora F)

Apesar de indicarem estar de acordo com a estruturação e organização do atendimento de sala de recursos no município, os professores não deixam de apontar aqui certa fragilidade do serviço, que fica submetido às relações no âmbito da escola, ao entendimento por parte dos gestores e às diretrizes da Secretaria de Educação do município que, em alguns momentos, transformam-se em entraves às ações e concepções por eles defendidas. 
Ao identificar essas relações e as interferências que sofre o atendimento desenvolvido pelos professores das salas de recursos, avaliamos como importante retomar a avaliação que os professores fazem desse serviço no início das entrevistas, referindo-se positivamente em relação à sua organização e estruturação, citando-a como "modelo". A que aspectos do trabalho os professores referem-se ao fazer essa avaliação? Parece-nos que, ao identificarem esse isolamento em relação ao coletivo da escola, os professores podem referir-se nesse momento inicial das entrevistas, ao seu próprio trabalho, às ações que desenvolvem com os alunos e, em alguns casos, com os professores das salas comuns, ou ainda em relação à estrutura física das salas, mobiliário e equipamentos, deixando de considerar nessa primeira avaliação esse contexto mais amplo que em alguns momentos, como veremos ao discutir seu posicionamento em relação ao público atendido, pode determinar a própria proposta de trabalho desenvolvida na sala de recursos, indo no sentido contrário às concepções dos professores.

Podemos afirmar que em relação a esse posicionamento inicial bastante positivo, os professores deixaram de considerar esse contexto em que se insere o atendimento da sala de recursos, realizando uma avaliação parcial do serviço ainda que, em alguns momentos, apontem avanços no decorrer desses anos de organização do atendimento.

\subsubsection{Papel do professor da sala de recursos}

Ao se referirem ao papel do professor da sala de recursos, os entrevistados compreendem que esse profissional tem uma atuação que vai além do atendimento aos alunos, entendendo seu trabalho como essencial ao processo de inclusão, sendo um parceiro do professor do ensino regular.

A sala de recursos, dentro de cada escola, é muito rica, porque o professor, além de trabalhar com o aluno, ele serve como um agente de inclusão dentro da escola. Ele faz a inclusão de fato acontecer. (professor A) Por que se o professor da sala de recursos em uma escola hoje, ele é o parceiro mais experiente nesse sentido de inclusão [...] (professor B) 
Ao avaliarem sua atuação dessa forma, com um papel que ultrapassa os limites da sala de aula, os professores de sala de recursos também podem indicar necessidades formativas que se referiram a esse papel, bem como avaliar as ações desenvolvidas pelo sistema municipal de São Bernardo, considerando que sua atuação se desdobra em ações que não só o atendimento aos alunos. Por esse motivo, julgamos que essa informação também auxiliará na avaliação das questões formativas que serão discutidas nas próximas páginas.

Essa atuação tem, a nosso ver, a possibilidade de transformar as influências identificadas pelos professores, principalmente aquelas presentes no contexto escolar mais próximo ao seu local de atuação. É importante confrontar essa percepção dos professores e o que pode ser apreendido sobre as perspectivas da Secretaria de Educação em relação ao papel que devem desempenhar nas escolas onde atuam e enquanto especialistas.

\subsubsection{Diversidade de público}

Ao informarem sobre o público atendido nas salas de recursos da rede municipal, os professores, que possuem habilitação/especialização na área da deficiência intelectual, vão descrever uma série de quadros e características dos alunos que ultrapassam a deficiência intelectual ou que a tem associada a outras deficiências, patologias e características dos alunos.

Ah, tem as crianças com distúrbio global do desenvolvimento, tem as crianças com paralisia, né, e... bom, aqui no $\mathrm{O}$ [escola] eu to atendendo até deficiente auditivo, né, porque como a $\mathrm{T}$ [professora da área de deficiência auditiva] se aposentou, né, então os dois menininhos que têm o problema de perda auditiva, eu que to atendendo, né.(professor I)-.

Ah, eu acho que tem um pouco de tudo. Eu acho que... então, tem alunos com deficiência, né, que tem uma síndrome que é diagnosticada, que você olha e vê que aquela criança é diferente, tem os alunos PCs [alunos com paralisia cerebral], que não obrigatoriamente têm uma deficiência, mas que necessitam de um tipo de apoio, de materiais [...]. (professor D)

Os meus alunos têm paralisia cerebral, né, a maioria são cadeirantes, que não falam, eu só tenho um cadeirante que fala, né, alguns cadeirantes que também não conseguem usar os braços, né, não têm uma coordenação pra isso, então tem a parte motora também, nem pra toque de cadeira, né, eu tenho aluno com síndrome, a Síndrome de Prader-Willi, lá no N [escola]. 
$\mathrm{Eu}$ tenho aqui nessa outra escola aluno também com deficiência intelectual e perda auditiva, usa aparelho, também era um aluno que eu... não fazia parte, né, de estar recebendo da outra área que é o auditivo, né, mas comecei a trabalhar com ele, por não ter a professora, né... ah. (professor E)

O que se evidencia nas entrevistas com os professores é a grande diversidade do público atendido na sala de recursos, até aqui, todos com uma característica comum que é a deficiência, seja ela física, intelectual ou, em alguns casos, auditiva, esta última com o apontamento de que a falta de um professor com habilitação nessa área foi o que motivou o atendimento pelos professores com formação em deficiência intelectual, ou com síndromes diversas e ainda quadros psiquiátricos (transtorno global do desenvolvimento).

Não há um estranhamento por parte dos professores sobre essa diversidade, confrontando-a com as especificidades de sua formação, o que revela que, na rede municipal de São Bernardo do Campo, os professores com formação na área de deficiência intelectual têm tomado para si o atendimento de alunos que apresentam características que não apenas as relativas à sua formação específica, mas também outros alunos, como os com transtorno global do desenvolvimento.

Esse aspecto poderá interferir tanto na avaliação das formações oferecidas pela Secretaria de Educação do município quanto nas indicações feitas pelos professores em relação aos temas que indicam para sua formação continuada.

\subsubsection{Equívocos nos encaminhamentos}

Ao lado da diversidade do público atendido pelo serviço de sala de recursos, mencionada na categoria anterior, os professores agregam àquele grupo alunos que apresentam questões de aprendizagem ou ainda problemas de comportamento.

É uma gama de trabalho muito grande que a gente tem aqui na sala de recurso, desde crianças que estão em processo de alfabetização, até 
crianças que não conseguem falar, que a gente tem que trabalhar com comunicação alternativa e o trabalho é muito variado, né. (professor A) Muitas crianças com problema de fono, que vem pra nós. Dislexia também tá aparecendo muito. São esses casos que... e de aprendizagem, que a criança passou por apoio e não conseguiu acompanhar, não deu conta, né, esse professor de apoio... é onde encaminha para sala de recursos. (professor $\mathbf{J}$ )

Os professores questionam a inserção desses alunos na sala de recursos, apontando uma distorção no seu encaminhamento e o risco de que, com esses equívocos, as crianças possam ser rotuladas como deficientes.

Bom, é bem variado. Na sala de recursos de São Bernardo é bem variado. Você atende aluno múltiplo, você atende aluno que às vezes troca algumas letras, tem algumas questões ortográficas apenas, acaba vindo sim pra sala de recursos." [...] Eu acho que também é uma falta de ajustes aí, porque eu não acredito que aluno com problema ortográfico seja público de sala de recursos. (professor B)

Às vezes o trabalho pedagógico lá atrás não deu conta, entendeu? E aí a sala de recursos vem como: "Ah! Então vamos lá, manda pra sala de recursos, que é deficiente”. Vamos tomar cuidado com rótulos, né. (professor C)

Essa distorção corresponde a outro aspecto já destacado pelos professores: a falta de compreensão, por parte das equipes gestoras, do trabalho realizado em sala de recursos, o que coloca os professores, muitas vezes, numa posição delicada, uma vez que compõem o grupo da escola e estão, de certo modo, submetidos às orientações da equipe de gestão da unidade. Esse fato tem, de acordo com nossa experiência, muitas vezes fragilizado as ações do professor, que não consegue manter o seu posicionamento e a defesa dos princípios de trabalho defendidos pela educação inclusiva, comprometendo sua atuação. Tem sido recorrente a solicitação, por parte dos professores, de que ações formativas sejam desenvolvidas também com as equipes gestoras das unidades escolares, principalmente discutindo o âmbito de atuação da educação especial e as especificidades do trabalho de sala de recursos. 


\subsubsection{Referências gerais à formação}

Os professores fazem uma série de afirmações sobre a formação que são de caráter muito genérico, não se referindo às formações que ocorreram ou que sentem como fundamentais para o desenvolvimento de trabalho, mas que indicam a importância dos processos formativos em função do trabalho realizado. As afirmações levam a uma avaliação sobre a necessidade e o valor dado à formação continuada e a necessidade do envolvimento dos participantes.

Eu acho que precisa ampliar as formações, sem dúvida. (professor B) Formação é importante, eu acho que sempre vai ser, mas o pessoal também tem que estar muito a fim de fazer, senão fica só encontro, ti,ti,ti. (professor I)

Bom, Edison, eu acho que é de suma importância, isso que me ajudou muito, muito, muito. (professor F)

\subsubsection{Formação inicial}

Ao se referirem à formação inicial, o que os professores deixam evidente é sua insuficiência em relação ao desafio colocado pelo trabalho nas escolas. É o primeiro momento em que a oposição teoria e prática aparecerá, marcando, na opinião dos professores, um distanciamento entre a universidade e a realidade das escolas, além do problema da transposição dos conteúdos teóricos abordados na formação inicial para a prática da sala de aula.

Olha, eu penso assim, vendo o meu trajeto curto, trabalhando na sala de recursos nove anos e na educação especial. A faculdade em si, ela não dá base nenhuma pra gente entrar e começar a trabalhar. (professor A)

Pra começar, que quem sai de um curso de pedagogia, mesmo com habilitação na área, você sai com a teoria, gente, você sai... mas a questão da deficiência, você desmistifica a questão da deficiência, você estuda Freud pra entender alguma coisa de deficiência, entendeu?! É tudo isso, mas é tudo no campo teórico. Na hora que você chega na sala e você dá de cara com um deficiente, gente, é muito diferente. (professor D) 
As afirmações dos professores sobre a distância entre a universidade e a sala de aula também podem revelar a necessidade de investimentos formativos que os auxiliem a realizar, autonomamente, a transposição da teoria para a prática e vice-versa.

\subsubsection{Formações externas, contratadas pela Secretaria de Educação de São Bernardo do Campo}

A preocupação com a formação dos profissionais da educação para o atendimento às “crianças diferentes" 9 surge no município de São Bernardo do Campo no início dos anos 90, com a criação de um programa de formação que contava com profissionais da própria rede municipal. Desde esse período, os responsáveis pela política de formação da Secretaria de Educação têm investido também na contratação de diferentes formadores para o desenvolvimento de cursos e palestras aos profissionais da rede municipal. Para avaliarem as formações contratadas pela Secretaria Municipal de Educação, os professores entrevistados pautaram-se em quatro cursos, oferecidos entre os anos de 2006 e 2009, período em que todos estavam atuando no serviço de sala de recursos.

A avaliação indica que essas formações não têm, no seu conjunto, trazido subsídios que favoreçam o desenvolvimento da proposta de trabalho, não refletindo, no dizer dos professores, as necessidades formativas do grupo.

Foi, mas que também a gente acabou achando muito maçante [referindose à formação B]. Você vê que eu nem lembro, to lembrando agora que você falou, mas quando me vem na cabeça, não, porque me parece que na época a gente achou que não acrescentou. (professor D)

Nesse sentido eu acho que é importante, às vezes seria muito mais legal você ter várias formações curtas, mas que tivessem assim um conteúdo, uma coisa que realmente chamasse a atenção do profissional também, porque às vezes vem, fala, fala, fala e não diz nada, né, do que às vezes leva um ano inteiro numa formação e chega no final do ano todo, você não ter conseguido usar nada daquilo que você aprendeu com a tua clientela. (professor I)

\footnotetext{
9 Denominação utilizada pela rede municipal no inicio da década de 90 para referir-se as crianças com necessidades educacionais especiais, conforme o documento de Proposta para Implantação da Inclusão na Rede Municipal de Educação de São Bernardo do Campo, 1999.
} 
Algumas afirmações dos professores parecem indicar o motivo dessa avaliação, que aponta um distanciamento entre o que é oferecido e as necessidades dos professores. A esse respeito os entrevistados referem-se novamente - a exemplo do que ocorreu quando se reportaram a questão da formação inicial - à relação entre teoria e prática. Esse é um fator essencial na avaliação dos professores: que o conteúdo das formações possa ser transposto para a prática no atendimento aos alunos.

Nesse aspecto não contribui [referindo-se às formações], fica... eu saio sem aquele gostinho de quero mais. Tá faltando alguma coisa, não que não foram válidas, foram. Mas faltou alguma coisa, tem algumas outras coisas que... mais práticas, essa coisa mais do dia-a-dia, meu, no meu... como a gente brinca, né, "meu arroz com feijão". Então eu sinto falta disso. (professor $\mathrm{H}$ )

Olha, Edison, eu to assim, eu questiono muito, sabe? Agora, ultimamente, porque assim, o curso que $\mathrm{C}$ deu é muita teoria, e teoria nós temos, a gente vem com essa bagagem desde a nossa especialização, entendeu? Então é assim, eu esperava muito mais do curso porque pra mim é mais a prática. (professor J)

Vamos esperar mais uns anos as pesquisas aí, ver o que sai [sobre TGD], que eu não consigo muito pegar essa teoria aí e juntar com a prática, é muito difícil. (professor B)

Essa valorização de formações que possibilitem uma aproximação da teoria com a prática, refletindo na atuação do cotidiano da sala de aula, é retomada ainda mais uma vez quando uma das formações contratadas é tomada como exemplo de um modelo a ser seguido.

Nós levamos os casos dos alunos. Eram discutidos com o grupo e ela [formador D], dentro da discussão, ela ia embasando teoricamente aquilo que a agente ia... então, assim, é outra perspectiva, quer dizer, você está participando, você está discutindo junto e construindo junto ali o aprendizado, ela não está só expondo pra você, né, o que ela tá fazendo, o que é legal e é necessário também, mas esse da discussão de casos, parece que traz um crescimento maior, uma construção maior [...]. (professor D)

O modelo de estudo de caso aparece com frequência na fala dos entrevistados com uma grande valorização, seja por permitir uma participação ativa dos professores no processo de formação, seja por oportunizar a aproximação entre teoria e prática, significando esta última a 
partir de um constructo teórico, uma tarefa que parece, em nossa leitura dos protocolos de entrevista e também em nossa prática cotidiana, ser ainda pouco executada pelos professores, motivo pelo qual talvez as formações com caráter mais teórico fiquem tão distantes das expectativas do grupo.

A possibilidade de uma ação formativa que favoreça e considere a fala dos professores já havia sido destacada quando, ao avaliar a organização e estruturação do serviço, apontou-se, de forma positiva, a escuta dos professores para definição da proposta e da atuação dos profissionais que trabalham em sala de recursos.

A investigação sobre essa dicotomia entre teoria e prática nos parece merecer maior aprofundamento, o que não será feito aqui por não constituir o foco de nossa pesquisa.

\subsubsection{Formações internas, sob a coordenação de profissionais da própria Secretaria de Educação de São Bernardo do Campo}

Assim como houve um investimento por parte dos gestores da Secretaria de Educação na contratação de profissionais para o oferecimento de cursos e palestras visando à formação continuada dos professores, também ocorreu um investimento interno, por meio da oferta, pelos profissionais que compõem a equipe de orientação técnica da Secretaria de Educação, do que foi denominado como encontros formativos.

Referindo-se a esses encontros, os entrevistados, assim como fizeram ao avaliar as formações contratadas pela Secretaria de Educação, valorizaram a aproximação com a prática e o cotidiano escolar, bem como a participação ativa no processo de formação.

Que foi o que a gente conseguiu naquelas reuniões de 2007 e 2008, que a gente mesmo colocava o que precisava e discutia, foi onde mais deu pra... saber, ler, ter conhecimento, trocar, adquirir alguma coisa. (professor B) Os grupos de estudo que a gente faz com a coordenação da equipe técnica, que a gente estuda os casos, são muito mais proveitosos pra gente do que vir uma pessoa de fora pra fazer uma formação em TGD, por exemplo, que abrange tudo, mas não foca o principal que é o aluno que a gente tem... (professor A) 
Como componente da equipe de orientação técnica da Secretaria de Educação de São Bernardo, acompanhei em 2007 e 2008 as reuniões formativas às quais se refere a fala da professora. Naquele momento, discutia-se a necessidade da reavaliação das orientações e procedimentos formulados em 2005; por esse motivo a pauta dos encontros referia-se às ações cotidianas dos professores, portanto à sua prática. Apesar de relacioná-las sempre às orientações legais vigentes naquele momento, o que se evidenciava para os professores era a discussão do seu dia-a-dia que, de certo modo, era complementada por outras ações formativas.

A valorização das discussões entre os profissionais da própria rede, bem como do conhecimento construído por esses profissionais ao longo dos anos de trabalho na educação especial, também surge quando se propõe uma avaliação dos processos formativos.

Ah, vou comentar uma coisa também, que eu acho legal da formação, às vezes não é só importante aquelas que vêm de fora, eu acredito muito que nós aqui dentro temos professores com muita experiência e capacidade pra dar uma formação pra nós mesmos, sabe, assim, tem professores que têm uma prática assim, com base teórica, tudo, que poderia estar dando também pra nós... (professor G)

Então, eu ainda acredito que a própria rede tem muito a oferecer pra gente, até com pessoas que estão há mais tempo na sala de recursos, com colegas mais experientes. (professor A)

A valorização dos saberes docentes e da aprendizagem entre pares é algo recorrente em nossa prática profissional junto aos professores de sala de recursos no município. Ela parece concordar com as afirmações de Gomez (1995) sobre a formação do professor reflexivo:

Em primeiro lugar, só a partir dos problemas concretos é que o conhecimento académico teórico pode tornar-se útil e significativo para o aluno-mestre. Em segundo lugar, o conhecimento que se mobiliza para enfrentar as situações divergentes da prática é do tipo idiossincrático, construído lentamente pelo profissional no seu trabalho diário e na sua reflexão na e sobre a acção. [...]. A prática deve mesmo constituir-se como ponto de partida do currículo de formação. (GÓMEZ, 1995 p. 111, grifos do autor)

\subsubsection{Propostas de formação - organização}


Ao indicarem as formações que atenderiam às suas necessidades, os professores destacam dois aspectos: a organização e os temas aos quais elas deveriam se referir. Nesta primeira categoria vamos nos deter na forma como poderiam ser organizadas, de acordo com a avaliação dos entrevistados, discutindo em seguida os temas indicados.

Um dos aspectos destacados vai de encontro à avaliação que realizaram sobre as formações oferecidas pela Secretaria de Educação, tanto externas quanto internas, e diz respeito ao estudo de caso. Esse é, sem dúvida, um modelo que, como dissemos anteriormente, atende a dois critérios propostos pelos professores como facilitadores e indicadores da qualidade de uma proposta de formação: a participação ativa dos professores e a aproximação entre teoria e prática.

Em suas indicações surgem ainda dois outros aspectos que mereceriam uma apreciação ao se formularem encontros/cursos formativos: a periodicidade e a relação com as preocupações e interesses dos professores. Da leitura que realizamos sobre esses dois pontos trazidos nos protocolos das entrevistas entendemos que, frente à diversidade do público atendido pela sala de recursos em São Bernardo do Campo, as necessidades formativas dos professores precisam ser avaliadas em dois âmbitos: o do conjunto dos professores e o das individualidades, uma vez que é recorrente a consideração pelo interesse do professor, como forma de garantir o seu envolvimento, na medida em que responde a uma necessidade percebida pelo próprio participante.

Então, Edison ... então, sempre no final do ano vocês pedem avaliação e uma das coisas que eu sempre coloco é que poderia fazer de acordo com o centro de interesse, né. (professor E)

Mas acho que em grupos pequenos, em grupos mais específicos, como foi feito no caso do TGD, que separou, pena que foi um bloco muito pequeno, muita gente ficou de fora, né. Mas assim, eu acho que pouca gente é realmente assim, focar um pouco, olha, vamos ver, qual a sua clientela, você encaixa aqui, é do seu interesse [...] (professor I)

[...] até então em uma das avaliações eu até coloquei, né, porque não ver o centro de interesse de cada pessoa e formar grupos de discussão, né, de estudos. Esses grupos teriam uma formação, né, porque você está estudando, você tá discutindo, então no final de um período você estaria com um grupo que seria um grupo que poderia acrescentar pro grupo maior [...] (professor E)

Estudo de caso que a gente se referia o tempo todo, não foi aquele, né, é esse estudo de caso que a gente fala, estudo de caso com essa assessoria, com essa organização. (professor D) 
[...] a formação tem que ser centrada nisso e uma coisa assim, é... com constância, então não demorar tanto, não ser nada extenso, mas que tenha começo, meio e fim... porque tudo que é muito extenso acaba se perdendo, as coisas acabam perdendo o foco, né, e por aí a gente acaba deixando de lado. (professor I)

\subsubsection{Propostas de formação - temas}

Quadro 7 - Temas apontados pelos professores entrevistados

\begin{tabular}{|c|c|}
\hline PROFESSOR & TEMAS \\
\hline A & $\begin{array}{l}\text { Alfabetização } \\
\text { Alimentação (aspectos clínicos - fonoaudiologia) } \\
\text { Terapia Ocupacional (estimulação física) } \\
\text { Psicomotricidade }\end{array}$ \\
\hline B & $\begin{array}{l}\text { Comunicação alternativa } \\
\text { Uso de softwares de comunicação } \\
\text { Currículo funcional } \\
\text { Avaliação }\end{array}$ \\
\hline C & $\begin{array}{l}\text { Acessibilidade } \\
\text { Tecnologia assistiva } \\
\text { Comunicação alternativa } \\
\text { Utilização de jogos pedagógicos } \\
\text { Transtorno Global do Desenvolvimento } \\
\text { Atendimento a alunos com deficiência múltipla }\end{array}$ \\
\hline $\mathbf{D}$ & Estudo de casos com assessoria (nesse caso, o professor optou pela forma e não pelo tema) \\
\hline $\mathbf{E}$ & Tecnologia \\
\hline $\mathbf{F}$ & $\begin{array}{l}\text { Processamento auditivo central } \\
\text { Dislexia }\end{array}$ \\
\hline $\mathbf{G}$ & Tecnologia assistiva \\
\hline $\mathbf{H}$ & $\begin{array}{l}\text { Libras } \\
\text { Braille }\end{array}$ \\
\hline $\mathbf{I}$ & $\begin{array}{l}\text { Transtorno Global do Desenvolvimento } \\
\text { Síndromes }\end{array}$ \\
\hline $\mathbf{J}$ & $\begin{array}{l}\text { Comunicação alternativa } \\
\text { Libras } \\
\text { Braille }\end{array}$ \\
\hline
\end{tabular}

Fonte: Entrevistas realizadas com professores de atendimento educacional especializado na cidade de São Bernardo do Campo/ SP pelo autor.

Ao indicarem suas necessidades formativas, os professores apontam temas que vamos categorizar em três áreas: conhecimentos pedagógicos - aqueles que se referem à ação pedagógica e que deveriam ser contemplados na formação inicial de todos os professores que atuam nos anos iniciais do ensino fundamental; conhecimentos clínicos - que estão relacionados a 
outras áreas de formação e que, apesar de se constituírem em conhecimentos que podem auxiliar o professor no seu dia-a-dia, não estão relacionados diretamente à prática pedagógica; e conhecimentos específicos - que dizem respeito às características e necessidades dos alunos atendidos muitas vezes pelos professores de educação especial, constituindo frequentemente a sua atuação com os alunos.

a) Conhecimentos pedagógicos: alfabetização, utilização de jogos pedagógicos e avaliação;

b) Conhecimentos clínicos: alimentação (aspectos clínicos - fonoaudiologia), terapia ocupacional (estimulação física), psicomotricidade, processamento auditivo central, dislexia, síndromes, transtorno global do desenvolvimento, deficiência múltipla;

c) Conhecimentos específicos: comunicação alternativa, softwares de comunicação, currículo funcional, acessibilidade, tecnologia assistiva, LIBRAS e Braille.

De acordo com o que foi discutido até o presente momento, e sendo coerentes com as afirmações a respeito dos centros de interesse, da relação teoria e prática e da diversidade do público, houve a indicação de diferentes temas, quase que podemos dizer que para cada professor entrevistado houve a indicação de um tema específico. Essa pluralidade de temas, em um universo relativamente restrito de entrevistados, nos leva a pensar na dificuldade encontrada pelo sistema no entendimento e atendimento a essa diversidade, seja no que se refere ao público atendido, seja no que diz respeito às diferentes experiências e necessidades indicadas pelos profissionais, bem como no pouco distanciamento que os professores conseguem tomar em relação ao seu cotidiano, mesmo quando a proposta é a indicação de ações formativas que correspondam às necessidades de um serviço que atende alunos de toda a rede municipal. Em alguns momentos, um mesmo professor indica diferentes temas, nem sempre relacionados entre si, o que tem nos levado a pensar nas inquietações que as mudanças pelas quais passa a proposta da política de educação especial têm provocado nos professores, particularmente as discussões em torno da Política Nacional de Educação Especial na Perspectiva da Educação Inclusiva de 2008.

Bom, acessibilidade, com certeza, né. A tecnologia assistiva, comunicação alternativa. [...] utilização de jogos pedagógicos, utilização de softwares pedagógicos [...] o DGD [Distúrbio Global do Desenvolvimento], né, eu creio que esse é o grande nó que a gente tem. $\mathrm{E}$ além de tudo, né, eu achei os múltiplos, né e o tal currículo funcional, né. (professor C) 
Pro desafio que eu vou ter a partir do próximo ano, eu to sentindo falta em LIBRAS, uma noção de Braille, certo? (professor $\mathrm{H}$ )

Como que eu percebo se uma criança é disléxica? Entendeu? Como que eu percebo? Como eu atinjo isso, como é que eu ajudo essa criança, então essas formações eu acho que são importantes. (professor F)

Eu preciso de tecnologia, eu preciso entender de tecnologia, eu preciso saber como que eu posso usar um computador e aquela criança que não mexe nada possa usar o rosto pra usar o teclado. (professor E)

\subsection{Apresentação e Discussão dos Dados dos Documentos}

Para proceder à análise documental tomamos como material de estudo as propostas de formação como organizadas pelos profissionais contratados, além das justificativas dessas contratações formuladas pela Secretaria de Educação do município de São Bernardo do Campo. Essas propostas de formação referem-se tanto às externas, contratadas, quanto às internas, organizadas pelos profissionais da equipe de orientação técnica da própria Secretaria de Educação.

A seguir serão apresentados quadros com resumos de cada categoria de documento analisado.

Quadro 8 - Formações contratadas pela Secretaria de Educação de São Bernardo do Campo entre os anos de 2006 e 2010

\begin{tabular}{|c|l|l|l|l|c|}
\hline & Ano & $\begin{array}{c}\text { Área de } \\
\text { formação do } \\
\text { formador }\end{array}$ & Título da formação & \multicolumn{1}{|c|}{ Público-alvo } & $\begin{array}{c}\text { Carga horária } \\
\text { (horas) }\end{array}$ \\
\hline A & 2006 & Pedagogia & $\begin{array}{l}\text { O Papel do Professor } \\
\text { Itinerante }\end{array}$ & $\begin{array}{l}\text { Profissionais do } \\
\text { ensino fundamental e } \\
\text { educação especial }\end{array}$ & 16 \\
\hline B & 2006 & Pedagogia & $\begin{array}{l}\text { O Papel do Professor } \\
\text { Itinerante: avanços e } \\
\text { desafios }\end{array}$ & $\begin{array}{l}\text { Profissionais de todas } \\
\text { as áreas de ensino }\end{array}$ & 16 \\
\hline C & 2008 & $\begin{array}{l}\text { Psicologia / } \\
\text { Psicanálise }\end{array}$ & $\begin{array}{l}\text { Transtornos Globais } \\
\text { do Desenvolvimento }\end{array}$ & $\begin{array}{l}\text { Professores Itinerantes } \\
\text { e de Sala de Recursos }\end{array}$ & 24 \\
\hline D & & Psicologia / & As escolas e os alunos & Professores e Equipes & 54 \\
\hline
\end{tabular}




\begin{tabular}{|l|l|l|l|l|l|}
\hline & 2009 & Psicanálise & $\begin{array}{l}\text { com Transtorno } \\
\text { Global de Orientação Técnica } \\
\text { Desenvolvimento do } \\
\text { (TGD) }\end{array}$ & $\begin{array}{l}\text { da Educação Especial, } \\
\text { Infantil e Erática Ensino } \\
\text { educacional erandamental } \\
\text { discussão }\end{array}$ & \\
Fun & & \\
\hline
\end{tabular}

Fonte: Processos de contratação de formadores, SMESBC.

É importante destacar que, apesar do público alvo de algumas formações se constituir, na proposta do formador, de professores do ensino fundamental ou de diferentes áreas de ensino, apenas a formação D foi oferecida a outro público (Equipes de Orientação Técnica), sendo as demais direcionadas apenas aos professores que atuavam em sala de recursos.

Quadro 9 - Objetivos das formações, de acordo com os formadores

\begin{tabular}{|c|c|c|}
\hline Formador & Objetivo Geral & Objetivos Específicos \\
\hline $\mathbf{A}$ & $\begin{array}{l}\text { Possibilitar aos profissionais graduados o } \\
\text { desenvolvimento da consciência crítica da } \\
\text { realidade educacional brasileira bem como a } \\
\text { capacidade de atuação profissional responsável e } \\
\text { eficiente, mediante fundamentação teórica } \\
\text { adequada no campo da Educação Inclusiva, } \\
\text { particularmente do Ensino Itinerante. }\end{array}$ & $\begin{array}{l}\text { - Fundamentar a prática educacional } \\
\text { do professor do Ensino Itinerante } \\
\text { nos aspectos teóricos e legais da } \\
\text { formação docente. } \\
\text { Conhecer e refletir sobre os } \\
\text { aspectos educacionais, sociais, } \\
\text { políticos e pedagógicos da } \\
\text { Educação Inclusiva. } \\
\text { Conhecer e refletir sobre as } \\
\text { relações do professor especializado } \\
\text { dentro da equipe técnico } \\
\text { pedagógica. } \\
\text { Conhecer e refletir sobre o papel } \\
\text { do professor de Ensino Itinerante. }\end{array}$ \\
\hline $\mathbf{B}$ & $\begin{array}{l}\text { Identificar e analisar no processo histórico } \\
\text { as mudanças de modelo da escola e o papel do } \\
\text { projeto político pedagógico, do planejamento e } \\
\text { do trabalho coletivo. } \\
\text { Analisar os documentos oficiais sobre as } \\
\text { possibilidades do trabalho pedagógico coletivo } \\
\text { a partir dos serviços de apoio, adaptações, } \\
\text { currículo, avaliação e terminalidade. } \\
\text { Refletir sobre as práticas pedagógicas diante do } \\
\text { paradigma da inclusão e a necessidade da gestão } \\
\text { democrática. }\end{array}$ & \\
\hline C & $\begin{array}{l}\text { O objetivo do curso é transmitir } \\
\text { conhecimentos acerca do tratamento e } \\
\text { escolarização de crianças com Transtornos } \\
\text { Globais do Desenvolvimento, com vistas à }\end{array}$ & \\
\hline
\end{tabular}




\begin{tabular}{|c|c|}
\hline & $\begin{array}{l}\text { preparação dos educadores para lidar com os } \\
\text { aspectos contemporâneos da educação, entre os } \\
\text { quais destaca-se a inclusão escolar de crianças e } \\
\text { jovens com necessidades educativas especiais. } \\
\text { A partir do referencial teórico da } \\
\text { psicanálise propõem-se um campo de sustentação } \\
\text { teórica que irá auxiliar esses profissionais na } \\
\text { reflexão e discussão do seu papel de educadores, } \\
\text { bem como na superação de impasses que essa } \\
\text { prática de trabalho implica. } \\
\text { O foco dos encontros de formação será a } \\
\text { temática da inclusão e escolarização de crianças } \\
\text { com necessidades educativas especiais. }\end{array}$ \\
\hline D & $\begin{array}{l}\text { Supervisionar o trabalho de escolarização } \\
\text { de alunos com distúrbios globais do } \\
\text { desenvolvimento na rede municipal de ensino de } \\
\text { São Bernardo do Campo, ampliando } \\
\text { possibilidades de práticas inclusivas e } \\
\text { promovendo investigações e reflexões acerca de } \\
\text { propostas educacionais a alunos portadores de } \\
\text { necessidades especiais. }\end{array}$ \\
\hline
\end{tabular}

Fonte: Processos de contratação de formadores. SMESBC

Quadro 10 - Justificativa da contratação das formações, de acordo com a Secretaria de Educação

\begin{tabular}{|c|c|}
\hline Formação & \multicolumn{1}{c|}{ Justificativa } \\
\hline \multirow{5}{*}{ A } & $\begin{array}{l}\text { O atendimento dos casos de inclusão escolar, ou seja, a alunos que apresentam } \\
\text { necessidades educacionais especiais nas classes do ensino regular devem ser feitos de forma } \\
\text { adequada, isto quer dizer que temos que ter professores especializados e recursos } \\
\text { necessários para este atendimento. E é isto o que temos oferecido a esta parcela da } \\
\text { população com o papel desempenhado pelo professor itinerante. É ele quem possui } \\
\text { conhecimentos específicos sobre como trabalhar com as dificuldades de ensino e } \\
\text { aprendizagem apresentadas por estes alunos, é quem irá auxiliar o professor do ensino } \\
\text { regular as estratégias, as adaptações de atividades, postura didática e outros. } \\
\text { Há então uma troca de interlocuções amiúde entre o professor da classe regular e o } \\
\text { professor itinerante. Isto em muito irá contribuir, pois cada um tem uma visão sobre as } \\
\text { dificuldades do aluno e juntos podem elaborar ações onde estes conhecimentos, percepções } \\
\text { irão auxiliar na ampliação das possibilidades de investimento na aprendizagem do aluno, por } \\
\text { estes professores. } \\
\text { O professor itinerante ainda para atendimento a estes alunos no período contrário } \\
\text { do ensino regular, trabalha com eles na sala de recursos onde ele considera em seu plano de } \\
\text { ação aquilo que o professor do ensino regular está trabalhando com seu grupo e, portanto, } \\
\text { vai gradativamente auxiliando este aluno para que possa ir progressivamente ocorrendo a } \\
\text { inclusão deste aluno nas atividades da classe regular. } \\
\text { Todas essas discussões e planos de trabalho são registradas para que se possa } \\
\text { resgatar os pontuados e assim elucidar eventuais clarificações. } \\
\text { O atendimento dos casos de inclusão escolar, ou seja, a alunos que apresentam } \\
\text { Becessidades educacionais especiais nas classes do ensino regular devem ser feitos de forma }\end{array}$ \\
\hline
\end{tabular}




\begin{tabular}{|c|c|}
\hline & $\begin{array}{l}\text { adequada, isto quer dizer que temos que ter professores especializados e recursos } \\
\text { necessários para este atendimento. E é isto o que temos oferecido a esta parcela da } \\
\text { população com o papel desempenhado pelo professor itinerante. É ele quem possui } \\
\text { conhecimentos específicos sobre como trabalhar com as dificuldades de ensino e } \\
\text { aprendizagem apresentadas por estes alunos, é quem irá auxiliar o professor do ensino } \\
\text { regular as estratégias, as adaptações de atividades, postura didática e outros. } \\
\text { Há então uma troca de interlocuções amiúde entre o professor da classe regular e o } \\
\text { professor itinerante. Isto em muito irá contribuir, pois cada um tem uma visão sobre as } \\
\text { dificuldades do aluno e juntos podem elaborar ações onde estes conhecimentos, percepções } \\
\text { irão auxiliar na ampliação das possibilidades de investimento na aprendizagem do aluno, por } \\
\text { estes professores. } \\
\text { O professor itinerante ainda para atendimento a estes alunos no período contrário } \\
\text { do ensino regular, trabalha com eles na sala de recursos onde ele considera em seu plano de } \\
\text { ação aquilo que o professor do ensino regular esta trabalhando com seu grupo e, portanto, } \\
\text { vai gradativamente auxiliando este aluno para que possa ir progressivamente ocorrendo a } \\
\text { inclusão deste aluno nas atividades da classe regular. } \\
\text { Todas essas discussões e planos de trabalho são registradas para que se possa } \\
\text { resgatar os pontuados e assim elucidar eventuais clarificações. } \\
\text { Este trabalho é claro é acompanhado pelo grupo gestor da unidade, que também é } \\
\text { responsável pela aprendizagem destes alunos. }\end{array}$ \\
\hline C & $\begin{array}{l}\text { A idéia de escola inclusiva surge mundialmente com maior ênfase na década de } 90 \\
\text { a partir do pressuposto: toda criança tem direito fundamental à educação, com possibilidade } \\
\text { de atingir e manter um nível adequado de aprendizagem. Ela possui características, } \\
\text { interesses e necessidades únicas. Assim as nossas unidades de ensino devem atender tal } \\
\text { diversidade oferecendo eficazmente a educação para todos, através de uma escola inclusiva. } \\
\text { A extensa gama de diferenças individuais existente entre os educandos a serem } \\
\text { atendidos nas instituições escolares exige que haja diversificação dos serviços e recursos } \\
\text { escolares (grifo no original), pois, conforme preconizam as sociedades democráticas, o } \\
\text { oferecimento de oportunidades educacionais é que torna possível uma escola de qualidade } \\
\text { para todos. Apostar e bancar a inclusão de alunos com TGD nos espaços escolares é } \\
\text { construir historicamente uma nova escola. } \\
\text { A escola como primeiro espaço organizado permite que essas crianças saiam do } \\
\text { lugar de "diferente" para o de aluno comum e, isto nos faz notar também mudanças } \\
\text { estruturais na família, ao ver seu filho na mesma escola do vizinho. } \\
\text { A escola se humaniza quando as famílias se agregam, se unem e se torna igualitária } \\
\text { mesmo quando a sociedade é segregacionista. } \\
\text { Em decorrência das especificidades surgidas no processo de inclusão dos alunos } \\
\text { com TGD, verificou-se a necessidade de instrumentalizar os profissionais que acompanham } \\
\text { estas crianças nas unidades escolares, sendo assim, esta formação tem como característica } \\
\text { um novo olhar para eles, que por questões específicas de seu desenvolvimento fragmentado, } \\
\text { por falhas nas construções subjetivas de fatores emocionais ou orgânicos, não são totalmente } \\
\text { respondidas num trabalho comum. }\end{array}$ \\
\hline D & $\begin{array}{l}\text { A Secretaria de Educação e Cultura de São Bernardo do Campo tem investido na } \\
\text { formação continuada dos profissionais da educação desde 1997, tendo como principais } \\
\text { documentos norteadores a Lei de Diretrizes e Bases da Educação Nacional (LDB), Plano } \\
\text { Nacional de Educação, Plano Municipal de Educação e mais recentemente a Lei } \\
11.494 / 2007 \text { e o Decreto n }{ }^{\circ} 6.253 / 2007 \text {, que regulamenta a criação do Fundo de Manutenção } \\
\text { e Desenvolvimento da Educação Básica e de Valorização dos Profissionais da Educação } \\
\text { (Fundeb), criado pela emenda Constitucional n } n^{\circ} \text { 53/2006, em substituição ao Fundef, que }\end{array}$ \\
\hline
\end{tabular}




\begin{tabular}{|c|}
\hline 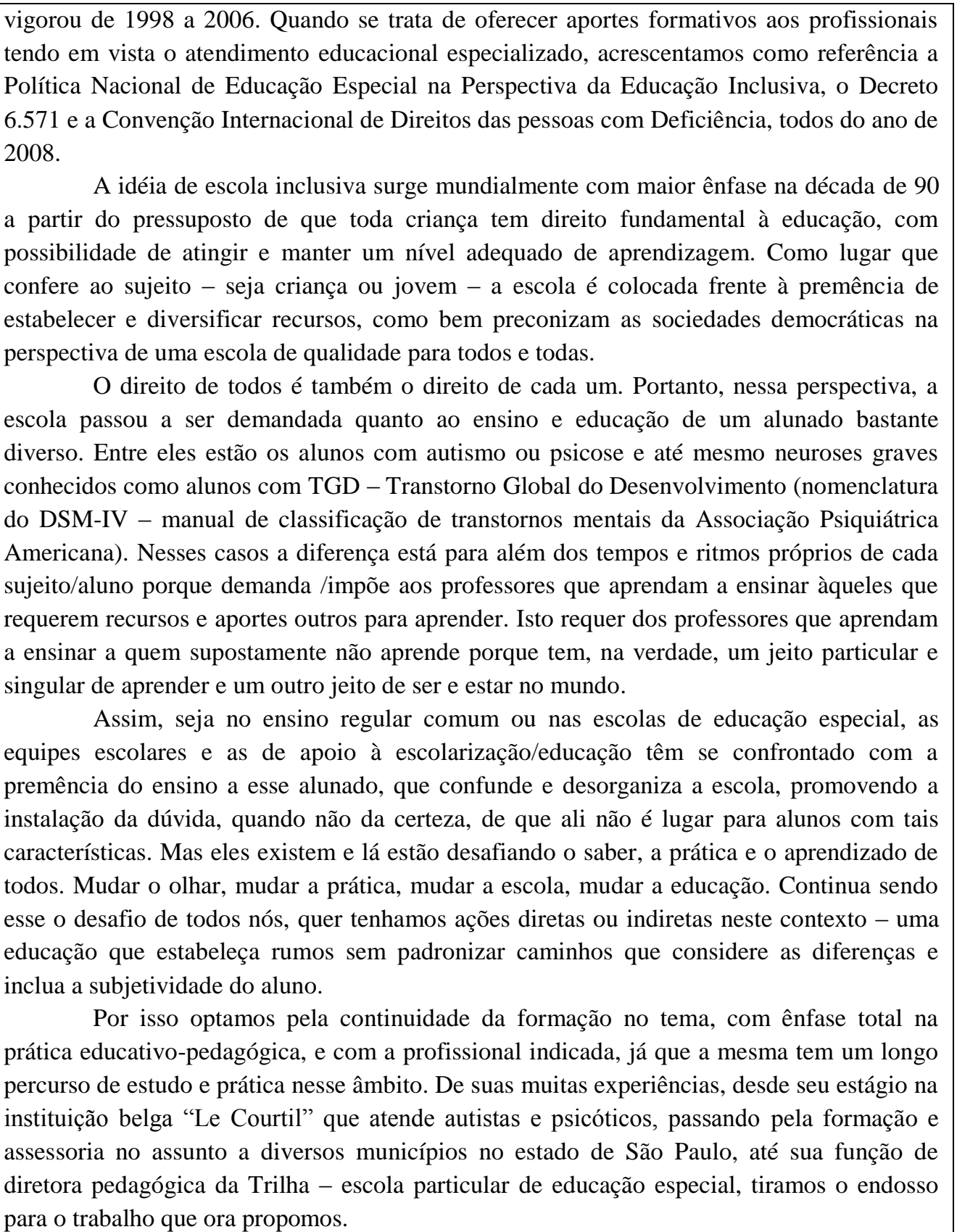 \\
\hline
\end{tabular}

Fonte: Processos de contratação de formadores. SMESBC.

Quadro 11 - Formações propostas pela equipe de orientação técnica da Secretaria de Educação de São Bernardo do Campo

\begin{tabular}{|c|c|c|c|}
\hline Ano & $\begin{array}{c}\text { Carga } \\
\text { Horária }\end{array}$ & Justificativa & Objetivos \\
\hline 2005 & \multicolumn{3}{|c|}{ Não foram localizados documentos com a proposta de formação } \\
\hline 2006 & \multicolumn{2}{|c|}{ Não houve formação } \\
\hline
\end{tabular}




\begin{tabular}{|c|c|c|c|}
\hline 2007 & 32 horas & $\begin{array}{l}\text { 1. A indicação feita pelos professores ao } \\
\text { final de } 2005 \text { da necessidade de } \\
\text { aprofundar as discussões sobre a } \\
\text { avaliação das necessidades } \\
\text { educacionais especiais e as adaptações } \\
\text { curriculares. } \\
\text { 2. Reavaliação, feita por psicólogos e } \\
\text { fonoaudiólogos da Equipe de } \\
\text { Orientação Técnica, indicando a } \\
\text { necessidade da discussão dos temas } \\
\text { indicados pelos professores. }\end{array}$ & $\begin{array}{l}\text { 1. Retomar e estabelecer, em } \\
\text { conjunto com os professores, } \\
\text { parâmetros em relação a } \\
\text { procedimentos que foram se } \\
\text { estabelecendo ao longo destes três } \\
\text { anos de funcionamento da sala de } \\
\text { recursos sob a orientação da seção } \\
\text { de ensino fundamental; } \\
\text { 2. Possibilitar ao grupo de } \\
\text { professores, a partir de } \\
\text { referenciais teóricos, momentos de } \\
\text { reflexão sobre as práticas } \\
\text { desenvolvidas. }\end{array}$ \\
\hline 2008 & 36 horas & $\begin{array}{l}\text { 1. Avaliação realizada ao final de } 2007 \\
\text { pelos professores e profissionais da } \\
\text { Equipe de Orientação Técnica. }\end{array}$ & $\begin{array}{l}\text { 1. Discutir e refletir sobre aspectos } \\
\text { relativos à prática cotidiana dos } \\
\text { professores que atuam em sala de } \\
\text { recursos no ensino fundamental, } \\
\text { que se distinguem das ações de } \\
\text { outros professores de educação } \\
\text { especial que atuam na rede. } \\
\text { 2. Aprofundar o conhecimento sobre } \\
\text { a itinerância construindo } \\
\text { orientações didáticas para sua } \\
\text { realização. } \\
\text { 3. Relacionar os conteúdos } \\
\text { trabalhados na formação com a } \\
\text { prática pedagóggica. }\end{array}$ \\
\hline 2009 & 20 horas & & 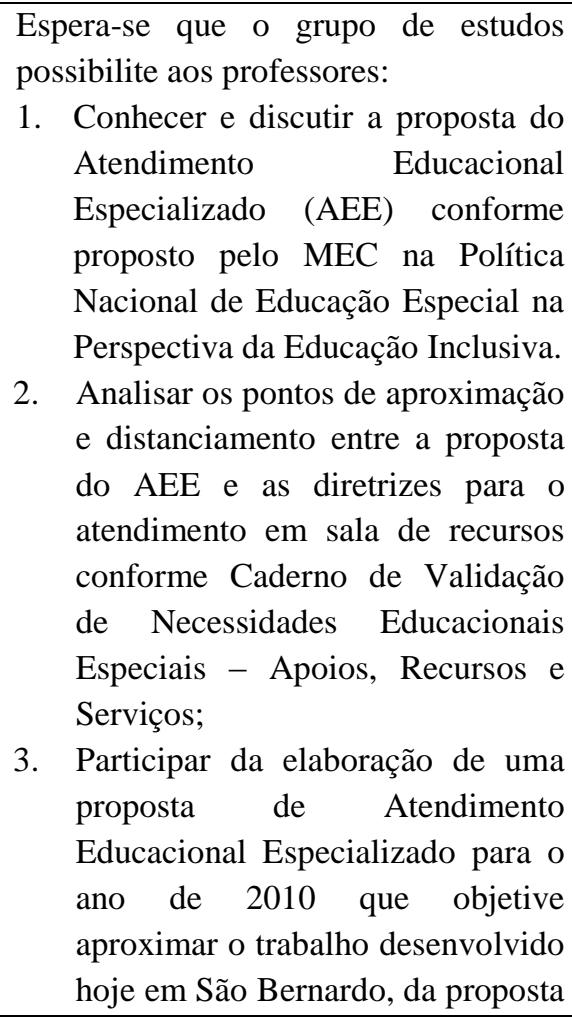 \\
\hline
\end{tabular}




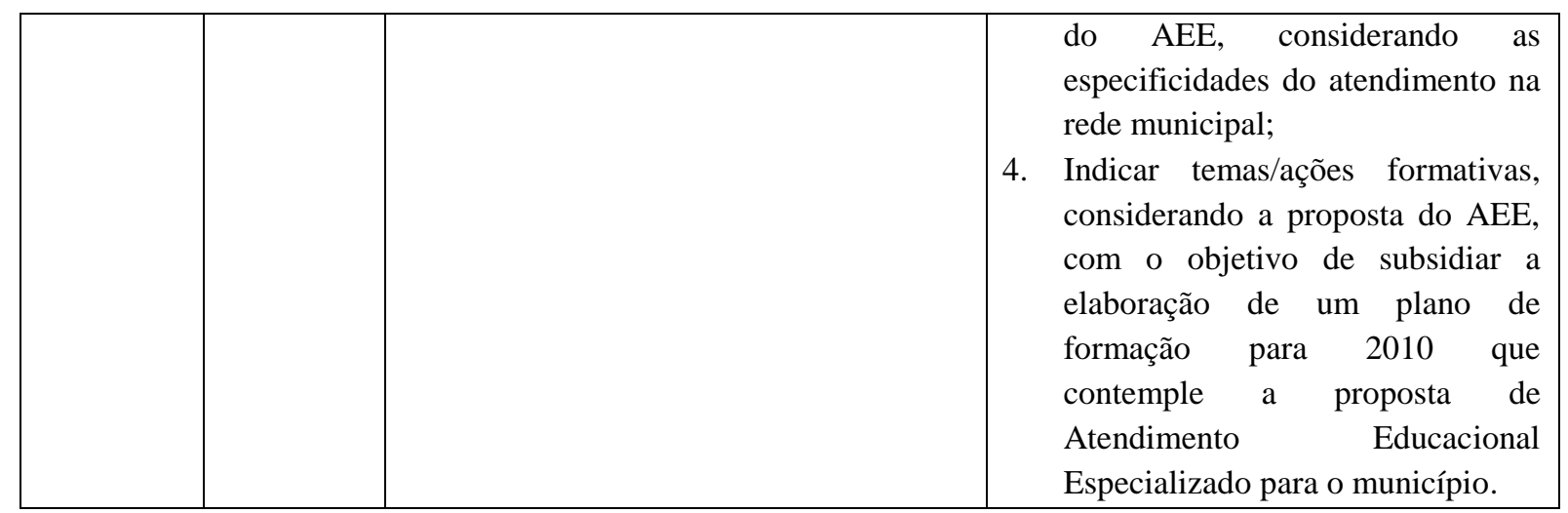

Fonte : Propostas de Formação elaboradas pela Equipe de Orientação Técnica da Seção de Ensino Fundamental da SMESBC

Em relação ao trabalho desenvolvido em 2005, apesar de não localizarmos um documento semelhante ao dos anos de 2007 a 2009, onde constam as justificativas e objetivos da formação, encontramos no documento intitulado "Validação - Caderno de Educação Municipal/Necessidades Educacionais Especiais: Informações sobre adaptações, apoios, recursos e serviços”, uma apresentação ao documento síntese das discussões realizadas em 2005 e que nos auxilia na compreensão da proposta desenvolvida naquele ano:

A partir da necessidade de definir os objetivos e procedimentos que norteiam o funcionamento das Salas de Recursos na Rede Municipal de Ensino de São Bernardo do Campo, a equipe de orientação técnica do Ensino Fundamental, representada pelos psicólogos e fonoaudiólogos integrantes e as professoras de Sala de Recursos que atendem as escolas da rede, reuniram-se sistematicamente no primeiro semestre de 2005 para elaborar e redigir este documento.

Sua finalidade é orientar gestores e professores quanto à forma de funcionamento deste serviço de apoio neste momento histórico da rede, onde procuramos consolidar, através de nossas práticas, a Educação Inclusiva em nosso sistema escolar, de acordo com o preconizado nos documentos internacionais e nacionais, bem como em nosso Caderno de Metas.

Esperamos, com isso, ter dado uma pequena contribuição a este grandioso, porém imprescindível desafio que a educação nos tem feito." (SBC, 2006, p. 92)

Ainda que o serviço de atendimento em salas de recursos para deficientes intelectuais tenha sido criado no município de São Bernardo do Campo no ano de 2000, conforme apontamos 
em capítulo anterior, os documentos disponíveis localizados durante a presente pesquisa refere-se ao período que vai de 2005 a 2009.

Esse é um primeiro dado que merece atenção. Apesar de haver, até o início de 2010, uma seção na Secretaria de Educação do município responsável pela formação dos profissionais da educação, esta não dispõe de um registro organizado que possibilite resgatar o histórico dos investimentos formativos realizados pela secretaria ao longo dos anos, o que dificulta a análise dos processos de formação implementados.

Feita essa ressalva, vamos iniciar nossa análise pelas justificativas formuladas pela Secretaria de Educação, ao propor a contratação das formações no ano de 2006. Vale ainda ressaltar que nesse período o serviço de sala de recursos para alunos com deficiência intelectual passava por um momento de discussão entre os profissionais da equipe de orientação técnica e os professores de sala de recursos, objetivando criar orientações para o desenvolvimento das diferentes ações compreendidas pelo serviço.

O que podemos perceber, a partir das justificativas apresentadas - idênticas, inclusive para a contratação das formações, é que elas apontam para uma responsabilização dos professores especializados em relação ao atendimento dos alunos com necessidades educacionais especiais, colocando-os no lugar de únicos conhecedores do processo de aprendizagem desses alunos.

Desse modo, ao justificar a contratação da formação, o texto da Secretaria de Educação diz que:

É ele [professor especializado], quem possui conhecimentos específicos sobre como trabalhar com as dificuldades de ensino e aprendizagem apresentadas por estes alunos, é quem irá auxiliar o professor do ensino regular as estratégias, as adaptações de atividades, postura didática e outros. (Formações A e B)

Há ainda nessa justificativa um argumento que sugere ter-se como objetivo do trabalho do professor especializado a normalização do aluno com necessidades educacionais especiais, adequando-o à proposta que o professor do ensino regular desenvolve com sua turma, promovendo, nessa concepção, a sua inclusão.

O professor itinerante ainda para atendimento a estes alunos no período contrário do ensino regular, trabalha com eles na sala de recursos onde ele considera em seu plano de ação aquilo que o professor do ensino regular 
está trabalhando com seu grupo e, portanto, vai gradativamente auxiliando este aluno para que possa ir progressivamente ocorrendo a inclusão deste aluno nas atividades da classe regular. (Formações A e B)

Ainda que se possam indicar objeções a essa perspectiva, o que não é o foco do presente trabalho, o que avaliamos como importante destacar é que ela não está contemplada nos objetivos indicados pelos formadores contratados. Ao contrário, analisando as propostas de formação, o que percebemos é um processo que objetiva desenvolver uma crítica ao modelo educacional atual por meio da análise do processo histórico da educação no país, situando o papel do professor especializado dentro do contexto pedagógico da escola, refletindo sobre sua atuação e relações no espaço escolar.

Assim, a proposta do formador A estabelece como objetivo:

Possibilitar aos profissionais graduados o desenvolvimento da consciência crítica da realidade educacional brasileira bem como a capacidade de atuação profissional responsável e eficiente, mediante fundamentação teórica adequada no campo da Educação Inclusiva, particularmente do Ensino Itinerante.

Identificar e analisar no processo histórico as mudanças de modelo da escola e o papel do projeto político pedagógico, do planejamento e do trabalho coletivo. (Formador A)

É possível então apontar aqui um descompasso entre as intenções da secretaria ao contratar as formações e a proposta dos formadores, o que indica um desconhecimento, por parte dos profissionais responsáveis pela política de formação da Secretaria de Educação, sobre as concepções e práticas dos formadores contratados. Uma vez que não se coadunam intenções e propostas, a própria formação fica prejudicada, já que a prática que ela objetiva instalar vai contra o modelo que, a partir da leitura das justificativas de contratação, a Secretaria busca implementar.

Cabe aqui uma observação em relação à análise proposta acima. O que estamos investigando no presente trabalho são as propostas de formação e é a partir dos documentos relacionados a esse processo que serão realizadas as análises. Não temos como objetivo discutir a política de inclusão da rede municipal de São Bernardo do Campo, ou mesmo verificar o quanto as propostas de formação inserem-se nessa política. Para isso seriam necessários outros estudos, o que não é nosso propósito, ainda que avaliemos que tal análise seja importante.

No mesmo período, nos anos de 2005 a 2007, a equipe de orientação técnica da Secretaria de Educação desenvolveu, com o mesmo grupo de professores, ações formativas que 
objetivavam, de acordo com os documentos, organizar o serviço de sala de recursos, que passava, como indicamos no capítulo sobre o histórico da educação especial no município, por uma reformulação.

Podemos afirmar que os objetivos dessa formação aproximam-se daqueles presentes nas formações contratadas em 2006, principalmente no que se refere a promover uma discussão entre os professores que favoreça a reflexão sobre suas práticas à luz de referenciais teóricos, o que contribui para o desenvolvimento de uma consciência crítica.

Assim, a formação apresenta como objetivos:

Retomar e estabelecer, em conjunto com os professores, parâmetros em relação a procedimentos que foram se estabelecendo ao longo destes três anos de funcionamento da sala de recursos sob a orientação da seção de ensino fundamental;

Possibilitar ao grupo de professores, a partir de referenciais teóricos, momentos de reflexão sobre as práticas desenvolvidas. (Formação 2007)

O que nos chama a atenção ao analisarmos as ações desenvolvidas pelos profissionais da equipe de orientação técnica da Secretaria de Educação é a sua formação: apenas psicólogos e fonoaudiólogos. Tanto na introdução do documento relativo à formação ocorrida em 2005 , quanto na justificativa da proposta em 2007, encontramos esses profissionais como os responsáveis pelo desenvolvimento das ações formativas. Esse fato sugere que a Secretaria de Educação permanece no modelo médico-pedagógico, que esteve presente na educação especial, desde o início de sua organização.

Aliando-se essa característica à justificativa das formações ocorridas em 2006, que evidenciava uma responsabilização dos professores especializados no atendimento dos alunos com necessidades educacionais especiais, podemos inferir, na leitura dos documentos, que o direcionamento dado pela Secretaria de Educação ao trabalho desenvolvido pela sala de recursos junto aos alunos com deficiência intelectual parte de pressupostos que privilegiam o conhecimento especializado, em detrimento do investimento nas ações pedagógicas, particularmente daquelas desenvolvidas pelos professores das classes comuns do ensino regular.

Nossa experiência na rede municipal nos permite afirmar que esse direcionamento comprometeu, em diferentes momentos, o desenvolvimento das ações dos professores da sala de recursos, o que avaliamos ter refletido numa avaliação negativa dos professores em relação às 
formações desenvolvidas, principalmente as contratadas pela Secretaria, uma vez que, de acordo com a avaliação dos professores, há um distanciamento entre teoria e prática.

Ao justificar a contratação da formação C, os profissionais da Secretaria de Educação indicam a necessidade da construção de uma "nova escola", por meio de mudanças que favoreçam o atendimento de todos os alunos, citando, mais especificamente, os com Transtorno Global do Desenvolvimento (TGD). Ficam enfatizadas, como forma de atendimento a todos os alunos, as mudanças que precisam ocorrer na escola regular.

Assim as nossas unidades de ensino devem atender tal diversidade oferecendo eficazmente a educação para todos através de uma escola inclusiva.

A extensa gama de diferenças individuais existentes entre os educandos a serem atendidos nas instituições escolares exige que haja diversificação dos serviços e recursos escolares, pois, conforme preconizam as sociedades democráticas, o oferecimento de oportunidades educacionais é que torna possível uma escola de qualidade para todos. Apostar e bancar a inclusão de alunos com TGD nos espaços escolares é construir historicamente uma nova escola. (Formação C, grifo no original)

Essa perspectiva é contemplada nos objetivos destacados pela formação que tem como foco "a temática da inclusão e escolarização de crianças com necessidades educativas especiais".

De acordo com a proposta de formação, o objetivo do curso é:

[...] transmitir conhecimentos acerca do tratamento e escolarização de crianças com Transtornos Globais do Desenvolvimento, com vistas à preparação dos educadores para lidar com os aspectos contemporâneos da educação, entre os quais destaca-se a inclusão escolar de crianças e jovens com necessidades educativas especiais. (Formador C)

Podemos afirmar que, de acordo com Éraut (apud Silva, 2000), essa formação pode ser compreendida a partir do paradigma do "déficit", em que a formação continuada objetiva:

"[...] preencher as lacunas da formação inicial, partindo do pressuposto que esta foi limitada e que os professores devem actualizar as suas competências práticas, como forma de tornar o sistema escolar mais eficaz." (SILVA, 2000, p. 30) 
No mesmo período em que essa formação se desenvolve, os profissionais da equipe de orientação técnica destacados para acompanhar o grupo de professores de sala de recursos, nesse ano composto por um psicólogo, uma fonoaudióloga e uma orientadora pedagógica, propõe uma formação que objetiva, a partir da prática, discutir o serviço intitulado como "itinerância". A perspectiva dessa formação pode ser compreendida no paradigma de crescimento, conforme proposto do Éraut: "De acordo com este paradigma, o conhecimento não reside apenas nos especialistas, mas, sobretudo, na experiência profissional dos professores e na reflexão que estes fazem da mesma [...]” (apud SILVA, 2000, p. 31).

No ano de 2009 a contratação da formação pela Secretaria de Educação teve como justificativa argumentos que dão continuidade ao proposto no ano anterior, ou seja, as modificações que devem ocorrer nas escolas comuns para o atendimento a todos os alunos, agora pautada nas legislações mais atuais, como a Política Nacional de Educação Especial na Perspectiva da Educação Inclusiva e a Convenção Internacional sobre os Direitos das Pessoas com Deficiência, destacando o objetivo da construção de uma educação inclusiva, dentro da proposta desses documentos.

Como lugar que confere ao sujeito - seja criança ou jovem - a escola é colocada frente à premência de estabelecer e diversificar recursos, como bem preconizam as sociedades democráticas na perspectiva de uma escola de qualidade para todos e todas.

$\mathrm{O}$ direito de todos é também o direito de cada um. Portanto, nessa perspectiva, a escola passou a ser demandada quanto ao ensino e educação de um alunado bastante diverso. Entre eles estão os alunos com autismo ou psicose e até mesmo neuroses graves conhecidos como alunos com TGD - Transtorno Global do Desenvolvimento (nomenclatura do DSM-IV - manual de classificação de transtornos mentais da Associação Psiquiátrica Americana). Nesses casos a diferença está para além dos tempos e ritmos próprios de cada sujeito/aluno porque demanda /impõe aos professores que aprendam a ensinar àqueles que requerem recursos e aportes outros para aprender. Isto requer dos professores que aprendam a ensinar a quem supostamente não aprende porque tem, na verdade, um jeito particular e singular de aprender e um outro jeito de ser e estar no mundo. (Formação D)

Os objetivos propostos pelo formador concordam com a justificativa apresentada, evidenciando como foco de trabalho o atendimento aos alunos com TGD e o desenvolvimento de práticas reflexivas, o que corresponde ao paradigma de crescimento proposto por Éraut (apud 
Silva, 2000): “[...] ampliando possibilidades de práticas inclusivas e promovendo investigações e reflexões acerca de propostas educacionais a alunos portadores de necessidades especiais".

Podemos distinguir, com base nas justificativas apresentadas pela Secretaria de Educação para a contratação de formações, dois movimentos distintos: um compreendido pelas propostas desenvolvidas em 2006 e outro em 2008/2009. O primeiro associado a um modelo médicopedagógico, que privilegia o atendimento especializado e a adequação dos alunos com necessidades educacionais especiais às propostas desenvolvidas pela sala comum da escola regular e a outra, que busca o movimento de transformação da escola regular para o atendimento a todos os alunos.

Em relação aos formadores, tanto contratados quanto da própria rede municipal, o que se percebe é a busca de uma aproximação da teoria e da prática, por meio da ação reflexiva dos professores sobre o seu cotidiano, associada a pressupostos teóricos que dão sustentação à prática. 


\section{CONSIDERAÇÕES FINAIS}

Iniciaremos essas considerações finais retomando nossa proposta de pesquisa, quando lançamos alguns questionamentos e nos propusemos a investigar esse tema a partir de duas questões orientadoras:

a) Quais necessidades formativas são indicadas pelos professores que realizam o atendimento educacional especializado dirigido aos alunos com deficiência intelectual na rede municipal de São Bernardo do Campo, matriculados nas escolas de ensino fundamental?

b) Quais ações formativas a Secretaria Municipal de Educação de São Bernardo do Campo tem oferecido aos professores especializados que atuam em sala de recursos no atendimento aos alunos com deficiência intelectual matriculados nas escolas municipais de ensino fundamental?

Com base nessas questões orientadoras, formulamos nossos objetivos de pesquisa:

1 Identificar quais são as necessidades formativas apontadas pelo grupo de professores que atua no atendimento aos alunos com deficiência intelectual, na modalidade de sala de recursos, na rede pública municipal de São Bernardo do Campo;

2 Investigar que ações formativas foram oferecidas no período de 2005 a 2009 pela Secretaria Municipal de Educação de São Bernardo do Campo aos professores de sala de recursos que atendem alunos com deficiência intelectual matriculados nas escolas municipais de ensino fundamental.

Foi a partir da consideração desses objetivos de pesquisa que optamos por realizar dois procedimentos de coleta de dados: as entrevistas com os professores do atendimento educacional especializado que atuam em sala de recursos e atendem aos alunos com deficiência intelectual e a análise dos documentos da Secretaria de Educação do município que se referissem à formação oferecida a esse grupo, notadamente as propostas de formação, como apresentadas pelos diferentes formadores, as justificativas formuladas pelos responsáveis pelas ações formativas da 
Secretaria para a contratação dessas formações e as ações desenvolvidas pelos profissionais da própria rede municipal que também tinham um caráter formativo e que foram desenvolvidas junto ao grupo de professores que atuava em sala de recursos no período estudado.

Realizados os levantamentos, procedemos à discussão dos dados, tendo como referência a análise de conteúdo, aplicada tanto às entrevistas como aos documentos, conforme proposta por Bardin (1977).

Feitos esses apontamentos iniciais, passamos a apresentar nossas considerações sobre o estudo realizado.

Ao analisarmos os documentos relativos às propostas de formação oferecidas pela Secretaria de Educação no período de 2005 a 2009, chama-nos a atenção o fato de não podermos localizar uma linha formativa adotada pela SMESBC nesse período, o que pode ser atribuído, pelo menos em parte, às mudanças ocorridas no organograma da Secretaria de Educação em 2007, quando a seção de educação especial passou a ser gerenciada não mais pela divisão de ensino, mas pela divisão de educação especial, educação de jovens e adultos e creches conveniadas, à mudança de gestão ocorrida em 2009, ou ainda, conforme as indicações de Tanuri (2000) e Saviani (2009), já apresentadas em capítulos anteriores, à forma com que a educação, e mais especificamente a formação de professores, vêm sendo expressa na legislação, com direcionamentos às vezes contraditórios, como discutimos ao apresentarmos a proposta de formação desenvolvida pelo MEC, no âmbito da Universidade Aberta do Brasil (UAB) e a deliberação do CEE de São Paulo no 94/2009.

O que se nota em nossa pesquisa são dois períodos distintos, representados pelas propostas e suas justificativas: 2006 e 2008/2009. O que diferencia esses dois períodos é, em nossa avaliação, a perspectiva adotada pela Secretaria de Educação frente às ações da educação especial e do ensino regular, que refletem discussões ocorridas ao longo dos últimos anos, particularmente nas três últimas décadas, sobre o atendimento dos alunos com necessidades educacionais especiais.

$\mathrm{Na}$ análise das ações formativas implementadas no primeiro período (2006), bem como na leitura do documento intitulado "Caderno de Validação. Necessidades Educacionais Especiais: Informações sobre adaptações, apoios, recursos e serviços”, publicado pela Secretaria Municipal de Educação de São Bernardo do Campo em 2006, podemos perceber dois aspectos importantes: o primeiro refere-se à responsabilização dos profissionais da educação especial que atuam no 
serviço de sala de recursos pelo atendimento dos alunos com necessidades educacionais especiais, colocando-os como únicos conhecedores do processo de ensino/aprendizagem desses alunos, o que, em nossa avaliação, tem colaborado para que esses sejam percebidos pelos profissionais das classes comuns das escolas regulares não como alunos da escola, mas como “alunos incluídos”, ou ainda "alunos de inclusão", designações que em nossa prática cotidiana ouvimos frequentemente e que os diferencia dos demais, contribuindo negativamente com uma proposta de educação para todos.

O segundo aspecto, ainda relacionado a essa concepção, apreendido na análise dos documentos oficiais da SMESBC, diz respeito à ação do professor de educação especial atuando em sala de recursos, que deveria objetivar a adequação dos alunos às propostas desenvolvidas pelo professor da sala comum do ensino regular, o que indica pouca diferenciação entre os objetivos da ação do professor especializado e do professor da classe comum, além da distorção em relação ao papel a ser desempenhado pelo professor especializado.

Em nosso entender, não ficam claros, nos documentos desse período, quais aspectos deveriam diferenciar o atendimento oferecido pela sala de recursos em relação à oferta feita pelo ensino regular em sala comum. Aparentemente, estava valorizada apenas a possibilidade de atendimento individualizado e mais constante por parte do professor especializado. Exemplo dessa concepção é a definição da "natureza do trabalho" a ser desenvolvido pela sala de recursos, expressa no Caderno de Validação.

O trabalho que vem sendo realizado nas salas de recursos do Ensino Fundamental possui um caráter pedagógico, visando favorecer a aprendizagem do aluno considerando a proposta curricular de seu ano/ciclo. As salas de recursos são organizadas de forma a favorecer intervenções mais individualizadas e constantes do professor. (SBC, 2006, p. 21)

É importante ressaltar ainda que as propostas formativas, conforme apresentadas pelos formadores contratados nesse ano, não correspondem em seus objetivos, aos pressupostos presentes nos documentos da SMESBC, o que revela uma falta de coerência entre as concepções da Secretaria e a formação oferecida. Esse aspecto pode ser responsável pela avaliação feita pelos professores em relação a essas formações, uma vez que indica um distanciamento entre o que foi oferecido (nomeado pelos professores como teoria) e sua prática diária. 
Se, por um lado, as justificativas apresentadas pela Secretaria para contratação dos profissionais deixa entrever uma visão marcada pelo modelo médico-pedagógico, com uma ênfase na ação dos especialistas para o atendimento aos alunos com necessidades educacionais especiais, atribuindo a eles todo o conhecimento necessário e, por que não dizer, a responsabilidade sobre o atendimento a esse alunado (o que também pode ser percebido na atribuição da coordenação das ações internas de formação a psicólogos e fonoaudiólogos da Secretaria), o mesmo não pode ser percebido nos objetivos propostos pelos formadores contratados. Ao contrário, as formações oferecidas em 2006 deixavam claro, nas propostas dos formadores, a intenção de problematizar o contexto educacional do período, considerando a responsabilidade da escola regular pelo atendimento de todos os alunos.

Nesse mesmo período, em função de outra mudança implementada em 2004 - a mudança do gerenciamento das ações desenvolvidas pelos professores de sala de recursos atuando no ensino fundamental - há um investimento na reorganização do serviço. Essa reorganização é contemplada nas ações desenvolvidas pelos profissionais da própria Secretaria.

O segundo período, compreendido pelas ações desenvolvidas em 2008 e 2009, indica uma concepção que objetiva a promoção de mudanças nas propostas desenvolvidas pelo ensino regular, com vistas ao atendimento de todos os alunos. Esse aspecto aparece contemplado nos projetos dos formadores, entretanto não estão expressas nos documentos da Secretaria as ações e os objetivos relativos ao atendimento de sala de recursos que possa contribuir com a consecução dessa proposta. Esse fato pode ser responsável por uma diferença de postura adotada pelos formadores contratados nesse período, e que foi expressa nos objetivos formulados em suas propostas:

O objetivo do curso é transmitir conhecimentos acerca do tratamento e escolarização de crianças com Transtornos Globais do Desenvolvimento, com vistas à preparação dos educadores para lidar com os aspectos contemporâneos da educação, entre os quais destaca-se a inclusão escolar de crianças e jovens com necessidades educativas especiais. (Formador C, grifos nossos)

Objetivo: supervisionar o trabalho de escolarização de alunos com distúrbios globais do desenvolvimento na rede municipal de ensino de São Bernardo do Campo, ampliando possibilidades de práticas inclusivas $e$ promovendo investigações e reflexões acerca de propostas 
educacionais a alunos portadores de necessidades especiais. (Formador $\mathrm{D}$, grifos nossos)

Essa diferenciação novamente parece-nos justificar a avaliação realizada pelos professores em relação às formações, quando apontam uma contribuição mais efetiva da formação D em relação às demais. Os objetivos propostos parecem estar de acordo com a visão que os professores têm de seu papel no contexto da educação inclusiva, quando apontam aspectos de sua ação que vão além do atendimento direto aos alunos, percebendo-se como "agentes de inclusão" e "parceiros mais experientes" dos professores do ensino comum.

Esses diferentes momentos, aliados ao descompasso entre as perspectivas da SMESBC em 2006 e as ações formativas desenvolvidas nesse ano, além da falta de clareza quanto ao papel atribuído ao professor especializado atuando em sala de recursos nos anos seguintes, compromete os investimentos formativos realizados no período estudado e apontam para a ausência de um plano de formação que favoreça a organização do serviço.

A falta de um direcionamento claro e de uma linha de formação é responsável, pelo menos parcialmente, pela avaliação feita pelos professores em relação às ações formativas ocorridas no período estudado. Em alguns momentos, na visão dos professores, elas estavam distantes da prática que desenvolviam, sendo percebidas como muito teóricas e não contribuindo com a efetivação de suas ações, ou ainda não considerarem ou mesmo desconhecerem os aspectos que caracterizavam a organização do atendimento em sala de recursos na rede municipal de São Bernardo do Campo.

Em relação às formações oferecidas pelos profissionais da equipe de orientação técnica podemos afirmar que caracterizavam, na perspectiva da Secretaria de Educação (pela constituição da equipe responsável pela sua coordenação: psicólogos e fonoaudiólogos), um modelo médicopedagógico, que não correspondia às perspectivas dos formadores contratados, e estavam voltadas à organização do serviço, dentro dos pressupostos da SMESBC, conforme apontado anteriormente.

O grande mérito dessas propostas internas, no dizer dos professores, foi considerar sempre as suas contribuições, ouvir os professores para, junto com eles, formular as diretrizes e organizar o serviço na rede municipal. Se considerarmos que, na avaliação dos professores, as demais formações estavam muito distantes de sua prática, é fácil compreender porque as propostas desenvolvidas pelos profissionais da rede tiveram uma avaliação positiva, não sendo questionada, 
nas entrevistas, a constituição desse grupo de coordenação, ainda que no dia-a-dia, por diversas vezes, houvesse a solicitação da participação de orientadores pedagógicos (pedagogos) nesse grupo, o que só veio a ocorrer em 2008. Cabe ainda indicar que essa perspectiva médicopedagógica, presente nos documentos elaborados como justificativa para contratação de algumas formações pela Secretaria de Educação do município, bem como na atribuição, aos profissionais fonoaudiólogos e psicólogos, da responsabilidade pela formação dos professores especializados, não se vê retratada na forma como esses profissionais formularam e conduziram esses encontros formativos, o que aponta para diferentes perspectivas mesmo em relação ao grupo que compõe os diferentes segmentos dentro da SMESBC.

Considerando as necessidades apontadas pelos professores, não apenas nas indicações de temas para formação como também nos aspectos que destacaram ao avaliar as formações desenvolvidas entre 2005 e 2009, além de outras considerações feitas no decorrer das entrevistas, podemos afirmar que os professores oscilam em suas avaliações e posicionamentos em relação a uma visão que ora apresenta-se abrangente, considerando o lugar em que se insere a educação especial e o serviço de sala de recursos, não apenas no município, mas no contexto da política nacional para a educação e ora apresenta-se particular, individualizada e talvez possamos dizer, imediatista.

Ao perceberem sua atuação de forma ampla, ultrapassando os limites do atendimento direto aos alunos e se colocando como parceiros dos professores do ensino regular, em ações que objetivam o atendimento a todos os alunos, demonstram um conhecimento e um posicionamento que está de acordo com as mais recentes discussões sobre a educação inclusiva, particularmente aquelas presentes em documentos como a Convenção sobre os Direitos das Pessoas com Deficiência, o Decreto $n^{\circ}$ 186/2008, que a regulamenta, e a Política Nacional de Educação Especial na Perspectiva da Educação Inclusiva.

Da mesma forma, os professores posicionam-se em relação ao encaminhamento dos alunos para o atendimento da sala de recursos, indicando inadequações nesse processo, o que tem levado, segundo eles, a equívocos tanto no que diz respeito às características e necessidades dos alunos inseridos, quanto na proposta desenvolvida, que muitas vezes confunde-se com as ações do ensino comum regular. Atribuem esses equívocos a um desconhecimento, por parte dos gestores das escolas, da proposta da sala de recursos, das próprias diretrizes da Secretaria de Educação ou mesmo das mudanças na legislação federal e na política de educação especial, 
entretanto não expressam a sua posição frente a esses equívocos, sugerindo um sentimento de impotência frente a esse posicionamento dos gestores.

A abordagem ampla e atualizada presente nas discussões dos professores em relação à sua atuação e ao contexto recente da educação especial está presente quando indicam a importância de investimentos formativos que contemplem o conhecimento dos professores, a sua atuação nas escolas e a construção coletiva do projeto de formação. De acordo com Imbérnon (2010, p.24), esses primeiros anos do século XXI têm se caracterizado por uma visão de formação que contempla a "criação de espaços e recursos para construir aprendizagem, mediante projetos de inovação e intercâmbio nas escolas. Processos de prática reflexiva”.

Por outro lado, ao identificarem as ações formativas necessárias ao desenvolvimento do serviço de sala de recursos no município, os professores voltam-se a um aspecto mais particular, dizendo de suas necessidades individuais, muitas vezes associadas às características dos alunos que estão atendendo no momento da realização da entrevista. Parecem desconsiderar, pelo menos parcialmente, as análises que fazem do contexto atual, seja das questões relativas à organização da rede municipal, seja das mudanças em relação à atuação da educação especial, centrando suas indicações nas necessidades percebidas no seu dia-a-dia.

Podemos observar nos temas propostos uma amplitude de assuntos que quase tornaria a formação individualizada. Esse movimento dos professores, retomando seu contexto diário de atuação e particularizando as propostas de formação, dificulta uma leitura que possa indicar uma linha formativa a ser seguida, tornando praticamente inviável a solicitação de que a Secretaria de Educação considere o interesse dos professores ao propor ações formativas. Entretanto, entendemos que esse movimento possa representar uma resposta dos professores à multiplicidade de solicitações que recebem, bem como à dificuldade da SMESBC, ao longo desses anos, de constituir um projeto claro para o serviço de sala de recursos, que mantivesse uma estabilidade nesses nove anos de implantação, o que pode ser percebido na análise das formações oferecidas no período de 2005 a 2009.

Ainda complementando esse quadro, como dissemos no capítulo anterior, ao analisarmos a categoria "Propostas de Formação - Temas" observamos que os professores fazem indicações de questões que se referem a conhecimentos pedagógicos, conhecimentos clínicos e conhecimentos específicos. Retomando essa categorização, julgamos importante considerar aqui três aspectos relacionados às solicitações dos professores: 
a) A formação inicial: ao indicarem temas como alfabetização e avaliação, os professores apontam para questões que deveriam estar contempladas em sua formação inicial, principalmente se considerarmos que praticamente todos, com exceção de apenas um professor, têm como primeira formação o curso de pedagogia.

b) Habilitação em Deficiência Intelectual: como requisito para admissão na rede municipal todos os professores devem comprovar formação em pedagogia com habilitação em deficiência intelectual ou curso de especialização (lato-sensu) em educação especial. Entretanto, hoje compõe o público da sala de recursos, como assinalaram os professores, uma grande diversidade de alunos, não apenas aqueles com deficiência intelectual. Essa diversidade, confrontada com a formação inicial dos professores especializados, parece justificar as necessidades indicadas no item relativo aos conhecimentos específicos, uma vez que esses parecem responder às características e necessidades dos alunos hoje atendidos pelos professores. Esse aspecto corresponde, por um lado, à importância de que a formação continuada considere as mudanças implementadas em decorrência das políticas públicas, subsidiando os professores para os novos desafios que são apresentados e, por outro lado, à necessidade de uma revisão na formação inicial, que considere o atual contexto da educação regular e especial, adequando-se à nova realidade e diminuindo o hiato entre a universidade e o cotidiano escolar.

c) Discussão sobre as atribuições do professor especializado: no momento em que muitas mudanças precisam ser implementadas para que a escola regular possa atender a todos, conforme prevê a legislação, é importante que se estabeleçam as formas de atuação, bem como os alcances esperados pela ação dos diferentes profissionais envolvidos no atendimento direto aos alunos, na gestão das escolas, das redes de ensino, das áreas de saúde etc. Destacamos os temas que categorizamos como "conhecimentos clínicos", pois entendemos que é importante que os professores tenham clareza sobre sua atuação em relação às questões físicas, de alimentação e outras apresentadas pelos alunos, não confundindo a ação pedagógica com o atendimento que corresponde à atuação de outros profissionais, como médicos, psicólogos, fonoaudiólogos, terapeutas ocupacionais etc.

A própria legislação necessita de maior clareza em relação aos conhecimentos que preconiza como necessários à ação pedagógica dos professores da educação especial, sob o risco de que as instituições responsáveis pela formação tenham diferentes entendimentos sobre sua 
responsabilidade na formação desses profissionais, mantendo o distanciamento já apontado entre universidade e escola ou entre teoria e prática.

A Política Nacional de Educação Especial na Perspectiva da Educação Inclusiva indica que:

Para atuar na educação especial, o professor deve ter como base da sua formação, inicial e continuada, conhecimentos gerais para o exercício da docência e conhecimentos específicos da área que possibilitem a sua atuação no atendimento educacional especializado, nas salas comuns do ensino regular, nas salas de recursos, nos centros de atendimento educacional especializado, nos núcleos de acessibilidade das instituições de educação superior, bem como aprofundar seu caráter interativo junto às salas de recursos.

Para assegurar a intersetorialidade na implementação das políticas públicas a formação deve contemplar conhecimentos de gestão de sistema educacional inclusivo, tendo em vista o desenvolvimento de projetos em parceria com outras áreas, visando à acessibilidade arquitetônica, aos atendimentos de saúde, à promoção de ações de assistência social, trabalho e justiça." (BRASIL, 2008)

Como se pode ver, são conhecimentos bastante amplos e que envolvem não apenas o contexto escolar, sendo fundamental uma discussão sobre a formação, seja ela inicial ou continuada, que corresponda a esse perfil profissional, bem como sobre a responsabilidade e atuação dos demais atores envolvidos no processo de escolarização de todos os alunos: coordenadores pedagógicos, diretores escolares, supervisores de ensino, técnicos, dirigentes regionais de ensino, secretários de educação etc.

Ao encerramos esse capítulo, retomando as questões orientadoras e os objetivos do presente estudo, algumas conclusões, ainda que parciais, mas possíveis para este momento, podem ser feitas:

1. Os professores, ao indicarem suas necessidades formativas, apontam diferentes temas que podem ser relacionados às questões não contempladas em sua formação inicial, seja ela no curso de pedagogia ou na habilitação/especialização em educação especial, ou que representam uma atualização de sua atuação, objetivando atender às mudanças no contexto educacional e às diretrizes para a educação especial, notadamente as expressas 
no documento de Política Nacional de Educação Especial na Perspectiva da Educação Inclusiva.

2. A Secretaria de Educação do município de São Bernardo do Campo ofertou diferentes ações formativas ao longo dos cinco anos que tomamos como referência para elaboração de nossa pesquisa. Entretanto, seja pelas características dos processos de contratação de profissionais, que não favoreceram uma aproximação entre as concepções e objetivos da SMESBC e aqueles propostos pelos formadores, seja por mudanças internas, ou ainda pela busca de adequação às mais recentes legislações, é possível afirmar que não houve a adoção de uma linha de formação que mantivesse um direcionamento claro auxiliando os profissionais na organização e estruturação do serviço de sala de recursos.

3. Os diferentes direcionamentos dados às ações formativas, aliados às questões internas, contribuem significativamente para não haver, entre os professores, uma coerência em relação às necessidades formativas apontadas e seu posicionamento frente o trabalho desenvolvido pelo atendimento educacional especializado no município.

Assim como os professores indicam a necessidade da aproximação entre teoria e prática, que em nosso entender pode ser compreendida como coerência entre concepções e ações formativas/estruturação interna, avaliamos como fundamental um processo de discussão que envolva professores e gestores com o objetivo de elaborar um plano de formação que, considerando os limites das gestões municipais, possa prever ações a curto e médio prazos que contribuam com a organização do atendimento educacional especializado, particularmente do serviço de sala de recursos e com a formação dos professores, com vistas a otimizar os investimentos realizados.

Considerando as indicações da Política Nacional de Educação Especial na Perspectiva da Educação Inclusiva de 2008, seria importante, em estudos futuros, aprofundar as discussões em torno das mudanças tanto na oferta do atendimento educacional especializado, uma vez que o texto do documento aponta para uma definição do público-alvo da educação especial como alunos com deficiência, transtornos globais do desenvolvimento e altas habilidades/superdotação, em lugar de alunos com necessidades educacionais especiais, quanto na formação dos professores para a realização desse atendimento, principalmente a partir da proposta de formação continuada organizada pelo MEC por meio da parceria entre a Universidade Aberta do Brasil e a 
Universidade Federal do Ceará, Universidade Estadual de Maringá e Universidade Estadual de São Paulo que vem se desenvolvendo desde 2007 para professores de todo o Brasil. 


\section{REFERÊNCIAS}

AJURIAGUERRA, J. . Manual de Psiquiatria Infantil. São Paulo: Masson.1975.

ALMEIDA, M. A. Formação do professor para a educação especial: história, legislação e competências. In: Revista Educação Especial, n. 24, 2004. Disponivel em: < http:// coralx.ufsm.br/revce/ceesp/2004/02> Acesso em 24 set. 2009.

AMERICAN PSYCHIATRIC ASSOCIATION. DSM IV - Manual Diagnóstico e Estatístico de Transtornos Mentais. Porto Alegre: Artmed. 1995

ANDRÉ, M. et al. Estado da Arte da Formação de Professores no Brasil. Revista Educação e Sociedade, Campinas, v. 20, n. 68, p. 301-309, dez. 1999.

ARANHA, M.S.F.. Paradigmas da relação da sociedade com as pessoas com deficiência. In: Revista do Ministério Público do Trabalho, Ano XI, n. 21, março, 2001, p. 160-173.

BARDIN, L. Análise de Conteúdo. Lisboa: Edições 70, Lda., 1997. 225 p.

BATISTA, C. A. M.; MANTOAN, M. T. E. Educação Inclusiva: Atendimento Educacional Especializado para a Deficiência Mental. Brasília: MEC/SEESP, 2005.

BAUMEL, R.C.R; SEMEGHINI, I. (Org.). Integrar / Incluir: desafio para a escola atual. São Paulo: FESUP, 1998. 148 p.

BENDA, C.A.P. Um Estudo sobre a Formação de Professores em Educação Especial. 2001. 66 f. Dissertação (Mestrado). Faculdade de Educação, Universidade de São Paulo, São Paulo, 2001.

BOGDAN, R; BIKLEN, S. Investigação Qualitativa em Educação. Uma Introdução à Teoria e aos Métodos. Portugal: Porto Editora, 1994. 335 p. (Colecção Ciências da Educação).

BOURDIEU, P. A Escola conservadora: as desigualdades frente à escola e à cultura. In .

Escritos de Educação. Petrópolis: Vozes, 2003. p. 39-64. 
A Miséria do Mundo. Rio de Janeiro: Petrópolis, 1997.

BRASIL. Senado Federal. Constituição da República Federativa do Brasil. Brasília, DF.: Senado, 1988.

Ministério da Educação. Secretaria de Educação Especial. Política Nacional de Educação Especial. Brasília, DF. 1994.

. Congresso Nacional. Lei de Diretrizes e Bases da Educação Nacional - LDB no 9.394 de 20 de dezembro de 1996. Diário Oficial da União, Brasília, DF. 23 de dezembro de 1996.

Ministério da Educação. Salto Para o Futuro. Educação Especial: Tendências Atuais. Secretária de Educação à Distância. Brasília, DF. , MEC, SEED, 1999. 96 p.

. Ministério da Educação. Plano Nacional de Educação. Brasília, 2001. Brasília, DF. Disponível em: < http://portal.mec.gov.br/arquivos/pdf/pne.pdf> Acesso em: 20 maio 2008.

Ministério da Educação. Conselho Nacional de Educação. Parecer n. 17 de 2001. Diretrizes Nacionais para a Educação Especial na Educação Básica. Brasília, DF. 2001. Disponível em: <http://www.mec.gov.br>. Acesso em: 14 mar. 2009.

Ministério da Educação. Conselho Nacional de Educação. Câmara de Educação Básica. Resolução no 2 de 2001. Brasília, DF. 2001. Disponível em: <http://www.mec.gov.br>. Acesso em: 09 mar. 2009

Ministério da Educação. Conselho Nacional de Educação. Câmara de Educação Básica. Resolução no 4 de 2002. Brasília, DF. 2002. Disponível em: < http://www.mec.gov.br>. Acesso em: 08 jul. 2010.

. Ministério Público Federal. O Acesso de Alunos com Deficiência às Escolas e Classes Comuns da Rede Regular. Brasília, DF.: Procuradoria Federal dos Direitos do Cidadão, 2004.

. Ministério da Educação. Instituto Nacional de Estudos e Pesquisas Educacionais Anísio Teixeira - INEP. Sinopse Estatística da Educação Básica. Censo Escolar 2005. Brasília, 2006. Disponível em: < http://www.inep.gov.br/basica/censo/Escolar/Sinopse/sinopse.asp>. Acesso em 04 mar. 2009 
. Ministério da Educação. Instituto Nacional de Estudos e Pesquisas Educacionais Anísio Teixeira - INEP. Sinopse Estatística da Educação Básica. Censo Escolar 2006. Brasília, DF. 2007. Disponível em: < http://www.inep.gov.br/basica/censo/Escolar/Sinopse/sinopse.asp> Acesso em 04 mar. 2009.

Ministério da Educação. Instituto Nacional de Estudos e Pesquisas Educacionais Anísio Teixeira - INEP. Sinopse Estatística da Educação Básica. Censo Escolar 2007. Brasília, DF. 2008. Disponível em: <http://www.inep.gov.br/download/censo/2007/sinopse_2007.zip>. Acesso em 02 mar. 2009.

Ministério da Educação. Política Nacional de Educação Especial na Perspectiva da Educação Inclusiva. Brasília, DF. 2008. Disponível em: < http://portal.mec.gov.br >. Acesso em: 12 maio 2008.

Senado Federal. Decreto $\mathbf{n}^{\mathbf{0}} \mathbf{1 8 6 / 2 0 0 8}$. Aprova o texto da Convenção sobre os Direitos das Pessoas com Deficiência e de seu Protocolo Facultativo, assinados em Nova Iorque, em 30 de março de 2007. Brasília, DF. 2008. Disponível em: <http://portal.mec.gov.br>. Acesso em 04 fev. 2009.

Decreto Presidencial $\mathrm{n}^{\circ} 6.571$ de 17 de setembro de 2008. Dispõe sobre o atendimento educacional especializado, regulamenta o parágrafo único do art. 60 da Lei $\mathrm{n}^{\mathbf{0}}$ 9.394, de 20 de dezembro de 1996, e acrescenta dispositivo ao Decreto $\mathrm{n}^{0}$ 6.253, de 13 de novembro de 2007. Diário Oficial da União, Brasília, DF. 17 de setembro de 2008. Disponível em: <http://www.planalto.gov.br/ccivil_03/ >. Acesso em: 04 mar. 2009.

BUENO, J.G.S. Educação Especial Brasileira: integração/segregação do aluno diferente. São Paulo: Educ., 1993.

CANDAU, V.M.F. Formação Continuada de Professores. In: REALI, A.M.M.R.; MIZUKAMI, M.G.N. (Orgs). Formação de Professores. Tendências Atuais. São Carlos: EdUFSCar, 1996. p. 139-152.

CORDIÉ, A. Os atrasados não existem. Psicanálise de crianças com fracasso escolar. Porto Alegre: Artmed Editora, 1996.

FERREIRA, J.R.. Políticas Educacionais e Educação Especial. In: Reunião Anual da AMPED, 2003. Caxambu. Banco de Dados e Artigos e Documentos. Caxambu. Educacaoonline, 2003. v.1, p. 1-15. 
A Exclusão da Diferença. Piracicaba: Unimep, 1993. 94 p.

FONTOURA, H.A. Ouvindo professoras de alunos com dificuldades de aprendizagem: um estudo etnográfico. Revista Brasileira de Educação Especial. Piracicaba, vol. 1, n. 2, p. 53-63, 1994.

FOUCAULT, M. A ordem do discurso. São Paulo: Edições Loyola, 2006.

A verdade e as formas jurídicas. Rio de Janeiro: Editora Nau, 2002.

GÉGLIO, P.C. Questões da Formação Continuada de Professores. São Paulo: Ed. AlfaOmega, 2006. $100 \mathrm{p}$.

GÓMEZ, A.P. O Pensamento Prático do Professor: a formação do professor como profissional reflexivo. In: Nóvoa, A.(Coord.). Os Professores e sua Formação. Lisboa: Publicações Dom Quixote. 1995.

GUHUR, M.L.P. A representação da deficiência mental numa perspectiva histórica. Revista Brasileira de Educação Especial, Piracicaba. Vol. 1, n. 2. p. 75-83, 1994

IMBERNÓN, F. Formação continuada de professores. Porto Alegre: Artes Médicas, 2010.

JANNUZZI, G. A Luta pela Educação do Deficiente Mental no Brasil. São Paulo: Editora Autores Associados, 1992. $123 \mathrm{p}$.

LEODORO, J.P. Inclusão Escolar e Formação Continuada: o programa Educação Inclusiva: direito à diversidade. 2008. 118f. Dissertação (Mestrado). Faculdade de Educação, Universidade de São Paulo, São Paulo, 2008.

LOPES, M.S.L. A formação continuada nas palavras dos autores. In: SOBRINHO, J.A.C.M.; CARVAlho, M.A.(Orgs.) Formação de Professores e Práticas Docentes: Olhares Contemporâneos. Belo Horizonte: Autêntica, 2006.p. 139-152.

LÜDKE, M; ANDRÉ, M.E.D.A. Pesquisa em Educação: Abordagens Qualitativas. São Paulo: EPU, 1986. 
MACHADO, A. M. Reinventando a avaliação psicológica. 1996. 232 f. Tese (Doutorado). Instituto de Psicologia, Universidade de São Paulo, São Paulo, 1996.

. Crianças de classe especial. Efeitos do encontro da saúde com a educação. São Paulo: Casa do Psicólogo, 1995.

MANTOAN, M.T.E. e BATISTA, C.A.M. Educação Inclusiva: Atendimento Educacional Especializado para a Deficiência Mental. Brasília: MEC, SEESP, 2005.

- Educação escolar de deficientes mentais: problemas para a pesquisa e o desenvolvimento. Cadernos CEDES. Campinas, v.19, n. 46, set./ 1998. Disponível em: < http://www.scielo.com.br>>. Acesso em: 11 set. 2006.

MARIN, A.J. Propondo um Novo Paradigma para Formar Professores a artir das Dificuldades e Necessidades Históricas nessa Área. In: REALI, A.M.M.R.; MIZUKAMI, M.G.N. (Orgs). Formação de Professores. Tendências Atuais. São Carlos: EdUFSCar, 1996. p. 153-165.

MARQUES, L.P. O professor de alunos com deficiência mental: concepções e práticas pedagógicas. 2000. 213 f. Tese (Doutorado). Faculdade de Educação, Universidade Estadual de Campinas. Campinas, 2000.

MAZZOTTA. M.J.S. Fundamentos de Educação Especial. (Série Cadernos de Educação). São Paulo: Pioneira, 1982. 137 p.

. Tendências da Formação de Professores de Excepcionais e sua Correlação com as Características da Educação Especial. Revista Brasileira de Educação Especial, Marília, v. 1, p. 7-13, 1992.

Trabalho Docente e Formação de Professores de Educação Especial. Temas Básicos de Educação e Ensino. São Paulo: EPU, 1993. 145 p.

. Educação Especial no Brasil. História e Políticas Públicas. São Paulo: Cortez, 2001.

MAZZOTI, A. \& GEWANDSZNAJDER, F. O Método nas Ciências Naturais e Sociais. São Paulo: Pioneira, 1998. 
MICHELS, N. H. Paradoxos da Formação de Professores Para a Educação Especial: o currículo como expressão da reiteração do modelo médico-pedagógico. Revista Brasileira de Educação Especial, Marília, v.11, n.2, maio/ago. 2005.

MINTO. C. Educação Especial: Da LDB aos Planos Nacionais de Educação - Do MEC e Proposta da Sociedade Brasileira. Revista Brasileira de Educação Especial. Marília, v. 06, nº 1, 2000.

MOYSÉS, M.A.A e COLLARES, C.A. L. Inteligência abstraída, crianças silenciadas: as avaliações de inteligência. Psicologia USP. São Paulo, v.8, n. 1, p. 63-89, 1997. Disponível em: < http://www.scielo.com.br>>. Acesso em: 14 jul. 2006.

MRECH, L.M. Os Desafios da Educação Especial, O Plano Nacional de Educação e a Universidade Brasileira. Revista Brasileira de Educação Especial, Marília, v.5, p. 127-146, 1999.

NÓVOA, A. A Formação de Professores e Profissão Docente. In Professores e a Sua Formação. Lisboa: Publicações Dom Quixote. 1995. (Coord.). Os O professor pesquisador e reflexivo. Disponível em 〈http://www.tvebrasil.com.br > Acesso em: 22 jun. 2010.

OMOTE, S. Deficiência e não-deficiência: recortes do mesmo tecido. Revista Brasileira de Educação Especial. Piracicaba, vol. 1, n. 2., p. 65-73, 1994.

PASCHOALICK, W.C. Análise do processo de encaminhamento de crianças às classes especiais para deficientes mentais desenvolvidos nas escolas de $1^{\circ}$ Grau da Delegacia de Ensino de Marilia. 1981. São Paulo. Dissertação (Mestrado). Pontifícia Universidade Católica de São Paulo. 1981.

PATTO, M.H.S. Para uma crítica da razão psicométrica. Psicologia USP, São Paulo, v.8, n. 1, p. 47-62, 1997. Disponível em: < http://www.scielo.com.br> . Acesso em: 11 set. 2006.

A produção do fracasso escolar. São Paulo: T.A.Queiroz, 1990. 
PETEAN, E.B.L. Recursos utilizados pelas famílias para promover o desenvolvimento do filho com síndrome de Down. 1987 São Carlos. Dissertação (Mestrado). Universidade Federal de São Carlos. 1987.

PICETTI, J.S. Formação Continuada de Professores: da abstração reflexionante à tomada de consciência. 2008. 144 f. Tese (Doutorado). Faculdade de Educação. Universidade Federal do Rio Grande do Sul. Porto Alegre, 2008. Disponível em <http://www.lume.ufrgs.br/bitstream/> Acesso em: 08 set. 2009.

PRIETO, R. G. Análise de Ações de Um Sistema Municipal de Ensino para Formação de Professores de Educação Especial, Revista InterMeio, Campo Grande, v.13, n. 25, p.84-95, janjun/ 2007.

Atendimento escolar de alunos com necessidades educacionais especiais: um olhar sobre as políticas públicas de educação no Brasil. In: ARANTES, V. A. (org.) Inclusão Escolar: pontos e contrapontos. São Paulo: Summus, 2006.

Os caminhos da Educação Especial e a Inclusão Escolar. Revista Unicsul, São Paulo, n. 9, p. 233-243, dez/2002.

QUEIROZ, Jr. E. O Diagnóstico de Deficiência Mental e suas Repercussões no Espaço Escolar na Perspectiva da Inclusão. 2006, 48 f. Monografia (Especialização). Faculdade de Educação. Universidade de São Paulo. São Paulo, 2006.

RIBEIRO, M.J.L. Formação de Professores: conhecendo as formas de organização curricular das especializações e as necessidades do professor para a prática de uma educação inclusiva. 2005. 242 f. Tese (Doutorado). Faculdade de Educação, Universidade de São Paulo, São Paulo, 2005.

RIBEIRO, M. L. S.; BAUMEL, R. (Org.). Educação Especial - do querer ao fazer. São Paulo: Avercamp, 2003.

RODRIGUES, D.B.; SOBRINHO, J.A.C.M. A Formação de Professores no Brasil: aspectos históricos. In: SOBRINHO, J.A.C.M.; CARVALHO, M.A.(Orgs.) Formação de Professores e Práticas Docentes: Olhares Contemporâneos. Belo Horizonte: Autêntica, 2006.p. 87-108. 
SÃO BERNARDO DO CAMPO. Secretaria de Educação. Proposta para Implantação da Inclusão na Rede Municipal de Educação de São Bernardo do Campo. São Bernardo do Campo, 1999.

. Secretaria de Educação. Necessidades Educacionais Especiais: Informações sobre adaptações, apoios, recursos e serviços. São Bernardo do Campo, 2006.

SÃO PAULO. Conselho Estadual de Educação. Deliberação CEE no 94/2009. Disponível em < http://www.ceesp.sp.gov.br > Acesso em: 14 abr. 2010.

SASSAKI, R.K. Inclusão: Construindo uma sociedade para todos. Rio de Janeiro, Brasil: WVA. 1997.

SAVIANI, D. Formação de professores: aspectos históricos e teóricos do problema no contexto brasileiro. In: Revista Brasileira de Educação, Rio de Janeiro, v. 14, n. 40, jan./abr. 2009.

SILVA, M. O. E. A análise de necessidades de formação na formação contínua de professores: um caminho para a integração escolar. 2000. 286 f. Tese (Doutorado). Faculdade de Educação. Universidade de São Paulo, São Paulo, 2000.

SILVA, S. C. Educação especial: formação de professores e aprendizagem da docência dos professores que atuam em sala de recursos. 2008. 151f. Dissertação (Mestrado). Universidade Federal de Mato Grosso, Cuiabá, 2008.

SOUSA, S.Z.L.; PRIETO, R. G. A Educação Especial. In. OLIVEIRA, R. P.; ADRIÃO, T. A Organização do Ensino no Brasil; Níveis e Modalidades na Constituição Federal e na LDB. São Paulo: Xamã, 2002, p. 123-138.

SOUZA, M.R.P. Formação do Psicólogo para atendimento a problemas de aprendizagem: desafios e perspectivas. In: Revista Estilos de Clínica, São Paulo, v.5, n. 9, p. 134-154. $2^{\circ}$ semestre de 2000.

Questão do rendimento escolar: mitos e preconceitos. In: CONCEIÇÃO, J.A.I. (org.) Saúde Escolar: a criança, a vida e a escola. São Paulo: Sarvier, 1994.p.125-132. 
SOUZA, T.C.B.O. Análise de uma Proposta de Formação Continuada de Professores no Contexto da Diversidade. 2008. 229 f. Dissertação (Mestrado). Faculdade de Educação. Universidade de São Paulo, São Paulo, 2008.

TANURI, L.M. História da Formação de Professores. Revista Brasileira de Educação, Rio de Janeiro, n. 14, p. 61-88, mai./jun./jul./ago. 2000.

TRIVIÑOS, A. N. Introdução à pesquisa em ciências sociais. São Paulo. Atlas, 1987

VIANNA, F.M.G. Política da Inclusão e a Formação de Professores. 2005. 156 f. Dissertação (Mestrado). Faculdade de Filosofia, Ciências e Letras. Universidade de São Paulo. Ribeirão Preto, 2005

ZEICHNER, K. M. O Professor como Prático Reflexivo. In. . A Formação Reflexiva de Professores: Idéias e Práticas. Lisboa: EDUCA, 1993. 


\title{
APÊNDICES
}

\author{
APÊNDICE A - Termo de consentimento livre e esclarecido
}

TERMO DE CONSENTIMENTO LIVRE E ESCLARECIDO

\begin{abstract}
$\mathrm{Eu}$,
\end{abstract}
RG.: professor especializado em Educação Especial, atuando na rede municipal de ensino de São Bernardo do Campo, no atendimento de Sala de Recursos, aceito participar do estudo denominado "A Formação Continuada dos Professores de Sala de Recursos: Desafios e Perspectivas", realizado por Edison de Queiroz Junior, junto ao programa de pós-graduação da Faculdade de Educação da Universidade de São Paulo, sob orientação da prof ${ }^{\mathrm{a}} \mathrm{dr}^{\mathrm{a}}$ Maria Luisa Sprovieri Ribeiro, que tem como objetivos:

1. Identificar quais são as necessidades formativas apontadas pelos professores que atuam no atendimento aos alunos com deficiência intelectual em sala de recursos, no município de São Bernardo do Campo.

2. Investigar que ações formativas são oferecidas pelo sistema municipal de São Bernardo do Campo, aos professores de sala de recursos que atendem alunos com deficiência intelectual.

Minha participação no referido estudo consistirá na concessão de entrevista ao pesquisador, que será gravada com minha autorização para posterior transcrição e análise, objetivando fornecer informações sobre a atuação profissional na Sala de Recursos e sobre as formações oferecidas pela rede municipal, bem como outras questões relativas à formação de professores.

Estou ciente de que meu nome, bem como qualquer outro dado pessoal que possa me identificar, será mantido em sigilo.

Também fui informado de que posso me recusar a participar do estudo, ou retirar meu consentimento a qualquer momento.

Enfim, tendo sido orientado e compreendido a natureza e objetivo do referido estudo, manifesto meu livre consentimento em participar. 
Nome e assinatura do entrevistado

Dados do pesquisador: Edison de Queiroz Junior

Tel: (11) 9964-5935

Email: edisonqueiroz@usp.br 


\section{APÊNDICE B - Roteiro de Entrevista}

Dados de identificação.

Nome

Idade: Tempo de formação em Educação Especial

Tipo de formação:

Onde fez sua formação:

Outras formações (especializações, aprofundamento. Local e Data.)

Inicio do trabalho como professor especializado:

Tempo de serviço na prefeitura municipal como professor especializado:

Tempo de atuação em sala de recursos na rede municipal:

Atua em outras redes?

Outros serviços de educação especial em que já atuou (escola especial, classe especial, etc):

1. Como vê a proposta de atendimento em sala de recursos na Prefeitura Municipal de São Bernardo do Campo?

2. Como caracteriza o público atendido na sala de recursos em São Bernardo do Campo ? 
3. Participou de formações oferecidas pelo sistema municipal de São Bernardo do Campo ao longo desse período de atuação na sala de recursos? Quais?

4. Como você avalia cada uma dessas formações em função da proposta de trabalho da sala de recursos?

5. Que outras formações avalia que seriam importantes para o desenvolvimento do seu trabalho na sala de recursos? Por quê?

6. Que outros comentários gostaria de acrescentar? 
APÊNDICE C - CD-ROM: Entrevistas. 